OPEN ACCESS

Edited by: Leonardo Cruz Da Rosa, Federal University of Sergipe, Brazil

Reviewed by: Hans Paerl,

University of North Carolina at Chape Hill, United States Natalya D. Gallo, University of California, San Diego, United States

*Correspondence: Thomas C. Malone malone@umces.edu

Specialty section: This article was submitted to Marine Biology, a section of the journal Frontiers in Marine Science

Received: 04 May 2020

Accepted: 22 July 2020

Published: 17 August 2020

Citation:

Malone TC and Newton A (2020)

The Globalization of Cultural Eutrophication in the Coastal Ocean:

Causes and Consequences.

Front. Mar. Sci. 7:670.

doi: 10.3389/fmars.2020.00670

\section{The Globalization of Cultural Eutrophication in the Coastal Ocean: Causes and Consequences}

\author{
Thomas C. Malone ${ }^{1 *}$ and Alice Newton ${ }^{2}$ \\ ${ }^{1}$ Horn Point Laboratory, University of Maryland Center for Environmental Science, Cambridge, MD, United States, ${ }^{2}$ Marine \\ Environmental Research Center, University of Algarve, Faro, Portugal
}

Coastal eutrophication caused by anthropogenic nutrient inputs is one of the greatest threats to the health of coastal estuarine and marine ecosystems worldwide. Globally, $\sim 24 \%$ of the anthropogenic $N$ released in coastal watersheds is estimated to reach coastal ecosystems. Seven contrasting coastal ecosystems subject to a range of riverine inputs of freshwater and nutrients are compared to better understand and manage this threat. The following are addressed: (i) impacts of anthropogenic nutrient inputs on ecosystem services; (ii) how ecosystem traits minimize or amplify these impacts; (iii) synergies among pressures (nutrient enrichment, over fishing, coastal development, and climate-driven pressures in particular); and (iv) management of nutrient inputs to coastal ecosystems. This comparative analysis shows that "trophic status," when defined in terms of the level of primary production, is not useful for relating anthropogenic nutrient loading to impacts. Ranked in terms of the impact of cultural eutrophication, Chesapeake Bay ranks number one followed by the Baltic Sea, Northern Adriatic Sea, Northern Gulf of Mexico, Santa Barbara Channel, East China Sea, and the Great Barrier Reef. The impacts of increases in anthropogenic nutrient loading (e.g., development of "dead zones," loss of biologically engineered habitats, and toxic phytoplankton events) are, and will continue to be, exacerbated by synergies with other pressures, including over fishing, coastal development and climate-driven increases in sea surface temperature, acidification and rainfall. With respect to management, reductions in point source inputs from sewage treatment plants are increasingly successful. However, controlling inputs from diffuse sources remains a challenging problem. The conclusion from this analysis is that the severity of coastal eutrophication will likely continue to increase in the absence of effectively enforced, ecosystem-based management of both point and diffuse sources of nitrogen and phosphorus. This requires sustained, integrated research and monitoring, as well as repeated assessments of nutrient loading and impacts. These must be informed and guided by ongoing collaborations among scientists, politicians, managers and the public.

Keywords: nutrients, pollution, eutrophication, services, hypoxia, biodiversity, habitats 


\section{INTRODUCTION}

During the course of the Twentieth century, increases in anthropogenic inputs of nitrogen $(\mathrm{N})$ and phosphorus $(\mathrm{P})$ to coastal ecosystems via river discharge to coastal ecosystems became the primary cause of eutrophication and consequent ecosystem degradation in coastal ecosystems worldwide (Rabalais et al., 2009, 2010; Paerl et al., 2014), a trend that is arguably the most widespread anthropogenic threat to the health of coastal ecosystems (Rabalais et al., 2009, 2010; IPCC, 2014). The European Union defines cultural eutrophication as The enrichment of water by nutrients, especially compounds of nitrogen and phosphorus, causing an accelerated growth of algae and higher forms of plant life to produce an undesirable disturbance to the water balance of organisms present in the water and to the quality of the water concerned, (European Commission, 1991). Nixon (1995) defined eutrophication as an increase in the rate of supply of organic matter to an ecosystem and noted that increases in the supply of organic matter to coastal ecosystems have various causes, the most common being excess inputs of labile, inorganic $\mathrm{N}$ and $\mathrm{P}$.

Organic matter (OM) in coastal ecosystems is derived from both autochthonous primary production and allochthonous inputs from outside the ecosystem. Evidence suggests that the coastal ocean as a whole has become net autotrophic (primary production of organic carbon $>$ respiratory metabolism of organic carbon) due to increases in anthropogenic inputs of inorganic nutrients (Deininger and Frigstad, 2019). This is consistent with the conclusion that increases in autochthonous phytoplankton production are the primary cause of cultural eutrophication in coastal ecosystems (Rabalais et al., 2009; Bauer et al., 2013). Hence, for our purposes, we define the process of cultural eutrophication as increases in the supply of organic matter to an ecosystem that is fueled by anthropogenic inputs of inorganic nutrients where increases in organic matter are most often due to excess ${ }^{1}$ phytoplankton production.

It is generally agreed that $\mathrm{N}$ is the primary cause of eutrophication in most coastal ecosystems ${ }^{2}$ (Howarth and Marino, 2006; Paerl, 2018). During the last half of the twentieth century, the global supply of dissolved inorganic nitrogen (DIN) doubled due to anthropogenic activities (Boyer and Howarth, 2008; Beusen et al., 2016; Lee et al., 2016). Anthropogenic inputs of $\mathrm{N}$ into the global environment (160 $\mathrm{Tg} \mathrm{N} \mathrm{yr}^{-1}$ ) now exceed

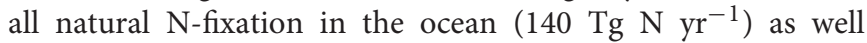
as the proposed planetary boundary ${ }^{3}$ of $62 \mathrm{Tg} \mathrm{N} \mathrm{yr}^{-1}$ (Steffen et al., 2015). By 2050, the anthropogenic production of DIN is expected to be $\sim 2$ times higher than in the 1990s (Galloway et al., 2004; Gruber and Galloway, 2008; Jickells et al., 2017). Thus, we focus on $\mathrm{N}$ enrichment as a pressure on ecosystem states and the resulting changes in ecosystems states as follows: (i)

\footnotetext{
1 "Excess" phytoplankton production occurs when the rate at which organic matter is produced exceeds the capacity of aerobic consumers and physical dilution to prevent accumulations of organic matter.

${ }^{2}$ This does not mean that phosphorus does not play a role (cf., Turner and Rabalais, 2013).

${ }^{3} \mathrm{~A}$ boundary beyond which human perturbations are predicted to destabilize the Earth's N cycle on a global scale.
}

impacts of anthropogenic $\mathrm{N}$ enrichment on coastal ecosystems; (ii) how ecosystem-specific characteristics minimize or amplify these impacts; (iii) synergies between nutrient enrichment and other anthropogenic pressures; and (iv) the management of anthropogenic nutrient inputs and their impacts.

\section{COASTAL ECOSYSTEMS AND SERVICES}

Sustainable development depends on healthy ecosystems that provide four categories of services valued by society (Millennium Ecosystem Assessment [MEA], 2005; United Nations Environment Programme [UNEP], 2006; Malone et al., 2014; Culhane et al., 2020):

- Regulating services (e.g., climate control $^{4}$, prevention of coastal erosion, limiting the extent and impacts of coastal flooding, and maintenance of water quality);

- Provisioning services (e.g., supplies of food, raw materials, and pharmaceuticals;

- Cultural services (e.g., recreational, aesthetic, and spiritual benefits); and

- Supporting services (e.g., presence of critical habitats ${ }^{5}$ and biodiversity, primary production of organic nutrients, oxic conditions, and optimal nutrient cycling) which underpin the capacity of coastal ecosystems to provide regulating, provisioning, and cultural services.

Coastal eutrophication threatens the provision of these services worldwide. Globally, people are concentrated in the coastal zone (Small and Cohen, 2004; Neumann et al., 2015) where the value of ecosystem services is greatest and where they are most at risk from convergent anthropogenic pressures (Halpern et al., 2008; Barbier et al., 2011; Cooley, 2012; Costanza et al., 2014, 2017; Elliff and Kikuchi, 2015; Solé and Ariza, 2019). Given synergies among these pressures (e.g., Rabalais et al., 2009; Newton et al., 2012; Bergström et al., 2019), management of anthropogenic nutrient enrichment should be implemented with due consideration of multiple pressures, especially over fishing (Worm et al., 2006), coastal development (Martínez et al., 2007), and climate-driven pressures (Huntington, 2006; HoeghGuldberg and Bruno, 2010).

\section{FRAMEWORK FOR ADDRESSING THE PROBLEM OF COASTAL EUTROPHICATION}

Cloern (2001) described the evolution of research on cultural eutrophication during the twentieth Century (phases I and II) and articulated a vision for how the problem can become better understood and managed during the twenty-first Century (phase III). Phase I focused on anthropogenic nutrient inputs as the

\footnotetext{
${ }^{4}$ Assimilation of carbon dioxide and heat from the atmosphere mitigates the impact of anthropogenic carbon emissions.

${ }^{5}$ For our purposes, critical habitats include both the pelagic habitat and biologically engineered benthic habitats (coral and oyster reefs, seagrass meadows, kelp forests, tidal marshes and mangrove forests).
} 
primary pressure on ecosystems and on the resulting changes in ecosystem states. Phase II expanded this approach to consider nutrient inputs in the context of other pressures including coastal development and over fishing. This underscored the need for ecosystem-based approaches (EBAs) ${ }^{6}$ to managing pressures on ecosystem services (Imperial and Hennessey, 1996; Levin and Lubchenco, 2008; UNESCO, 2012).

Guided by five questions, Phase III articulates a way forward for the twenty-first century (Cloern, 2001):

(i) How do ecosystem-specific attributes constrain or amplify the effects of anthropogenic nutrient enrichment on ecosystem states?

(ii) How does nutrient enrichment interact with other pressures to alter ecosystem states?

(iii) How are multiple state-changes related to multiple pressures?

(iv) How do changes in ecosystem states impact the health and wellbeing of species, including Homo sapiens?

(v) How can advances in scientific understanding of eutrophication be applied to manage and mitigate the effects of multiple anthropogenic pressures?

The Driver-Pressure-State-Impact-Response model (Bowen and Riley, 2003; Niemeijer and de Groot, 2008; Elliott et al., 2017) provides a framework for understanding the linkages between drivers (e.g., population growth, industrial agriculture, and combustion of fossil fuels) that generate pressures, changes in ecosystem states and services, and human responses to these changes (Figure 1).

\section{NUTRIENT ENRICHMENT}

\section{Global Trends and Patterns}

Phytoplankton production is both the foundation of most marine food webs that support provisioning services and a source of excess organic matter that often leads to coastal eutrophication. Today, coastal eutrophication is a global problem (Figure 2), especially in the northern hemisphere, along the western margins of the Atlantic and Pacific Oceans, and in European coastal waters (Howarth, 2008; Nixon, 2009; Rabalais et al., 2009, 2010; Cloern and Jassby, 2010; Cloern et al., 2014).

In five years (1998-2003), surface chlorophyll-a (Chl) ${ }^{7}$ concentration increased by $10 \%$ in the coastal ocean (Gregg et al., 2005), largely as a consequence of land-based, anthropogenic $\mathrm{N}$ inputs (Justić et al., 1995; Jørgensen and Richardson, 1996; IPCC, 2014). Changes in coastal ecosystem states due to coastal eutrophication include:

\footnotetext{
${ }^{6}$ Ecosystem-based approaches (i) emphasize the protection of ecosystem structure and function; (ii) are place-based; (iii) explicitly account for interactions among species (including humans) and between species and their environment; (iv) consider interactions among ecosystems; and (v) integrate ecological, social, economic, and institutional perspectives.

${ }^{7}$ An index of phytoplankton biomass.
}

- The occurrence of dead zones (hypoxic or anoxic ${ }^{8}$ ) zones that develop when excess organic matter sinks below the pycnocline ${ }^{9}$ where it is metabolized by aerobic, heterotrophic bacteria (cf., Malone et al., 1988). The number of oxygen depleted coastal ecosystems has increased globally from $<5$ prior to WWII to $\sim 700$ today (Vaquer-Sunyer and Duarte, 2008; Altieri and Diaz, 2019; Diaz et al., 2019), a number that may be an underestimate due to under sampling of the coastal ocean, especially in the southern hemisphere (Altieria et al., 2017; Diaz et al., 2019).

- Harmful algal blooms appear to be increasing in frequency, and there is a growing consensus that cultural eutrophication is at least partially responsible (Anderson et al., 2002; Heil et al., 2005; Glibert et al., 2008; Heisler et al., 2008; Glibert, 2017; Glibert and Burford, 2017).

- Habitat loss is a global problem as warm-water coral reefs have declined by at least 50\% (D'Angelo and Wiedenmann, 2014; Hoegh-Guldberg et al., 2017), seagrass meadows by 29\% (Orth et al., 2006; Waycott et al., 2009; Deegan et al., 2012), and coastal wetlands (mangrove forests and salt marshes) by 30\% (Valiela et al., 2009; Deegan et al., 2012). A common theme accompanying these losses is the impact of anthropogenic nutrient loading.

\section{Sources of Anthropogenic Nitrogen}

Over half of the DIN input to coastal ecosystems (including $73 \%$ of Large Marine Ecosystems ${ }^{10}$ ) is related to anthropogenic sources (Galloway et al., 2004; Howarth, 2008; Lee et al., 2016). An average of $\sim 20 \%$ anthropogenic $N$ inputs to coastal watersheds is exported to coastal ecosystems (Howarth et al., 1996; Howarth, 1998), and Galloway et al. (2004) predict that export will increase by $40-45 \%$ by 2050 relative to 2000 . Nearly half of this increase is projected to be from South Asia, where industrial agriculture and urbanization are expected to show the greatest increases (Howarth and Marino, 2006; Goldewijk et al., 2011; Lee et al., 2016). Ranked in terms of the magnitude of $\mathrm{N}$ loading, major ${ }^{11}$ anthropogenic sources include:

(i) Synthetic Fertilizers - The largest source of anthropogenic $\mathrm{N}$ transported to coastal ecosystems is the use of synthetic fertilizers (Vitousek et al., 1997; Johnson and Harrison, 2015), which has grown exponentially from near zero in 1910 to $\sim 118 \times 10^{9} \mathrm{~kg} \mathrm{~N} \mathrm{yr}^{-1}$ in 2013 (Penuelas et al., 2013; Lu and Tian, 2017). In 2013, southern Asia accounted for $71 \%$ of global fertilizer use, followed by North America (11\%), Europe (7\%), and South America

\footnotetext{
${ }^{8}$ Hypoxia, dissolved oxygen concentration $\leq 2$ mg liter $^{-1}$; anoxia, water depleted of dissolved oxygen.

${ }^{9} \mathrm{~A}$ rapid increase in density with depth in the water column which separates a vertically mixed surface layer from bottom water.

${ }^{10}$ The global network of large marine ecosystems (LMEs) includes coastal watersheds and the coastal ocean (estuaries and the open waters of the continental shelves). LMEs vary in size from $\sim 200,000 \mathrm{~km}^{-2}$ to $>1,000,000 \mathrm{~km}^{-2}$ and encompass areas of the coastal ocean where primary productivity is generally higher than in the open ocean (Sherman, 1991).

${ }^{11}$ In addition to the major sources listed below, there are many, relatively minor, additional sources including industrial sources, especially from biomass and food processing, e.g., paper mills, dairy, brewing.
} 


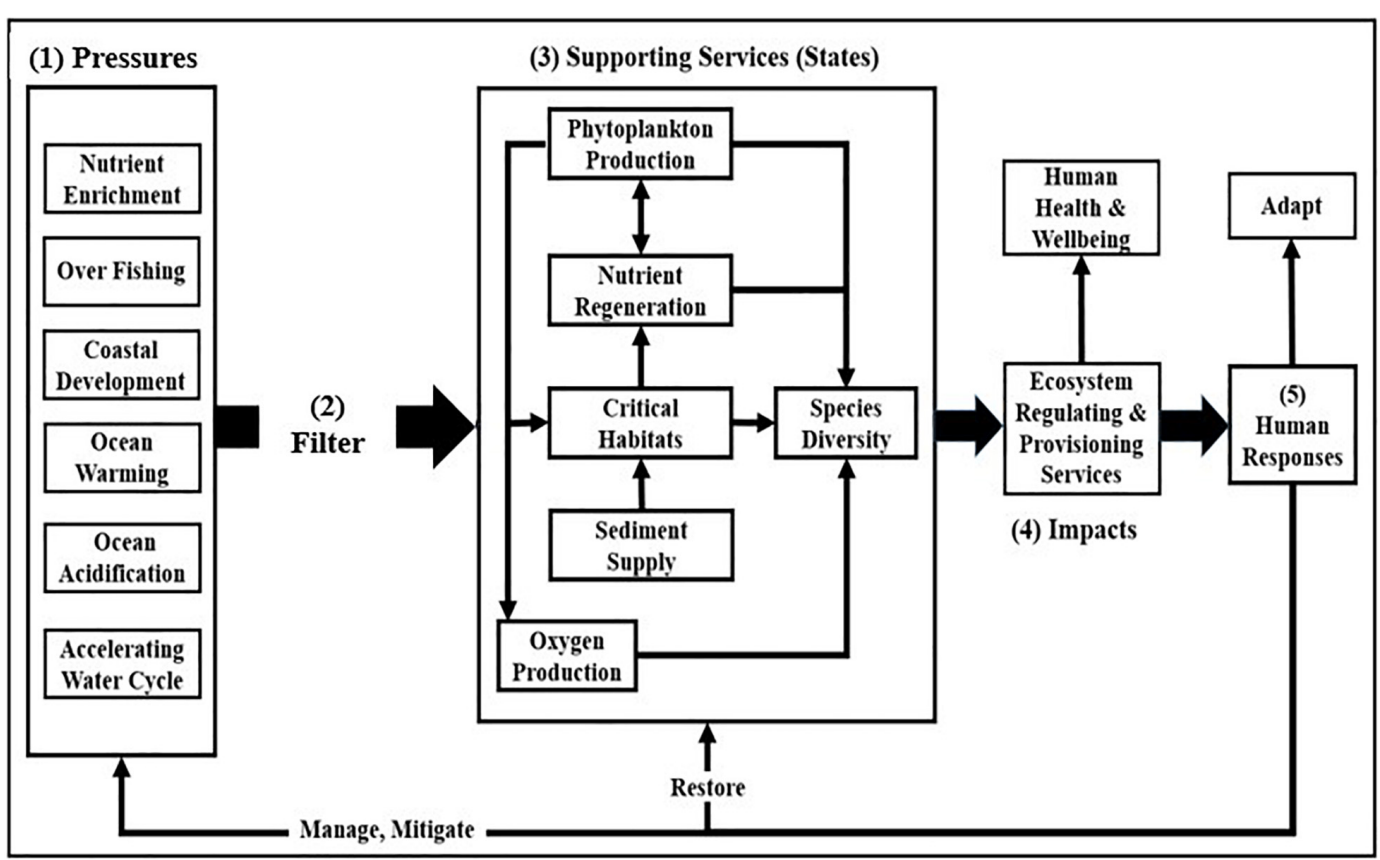

FIGURE 1 | The framework is conceptualized in terms of (1) anthropogenic pressures on ecosystem support services that (2) are uniquely modulated by each ecosystem as they perturb (3) ecosystem support services (states), changes in which impact (4) regulating and provisioning services. Human responses to these impacts (5) include efforts to manage and mitigate pressures, to restore supporting services, and to adapt to changes in states (modified after Cloern, 2001).

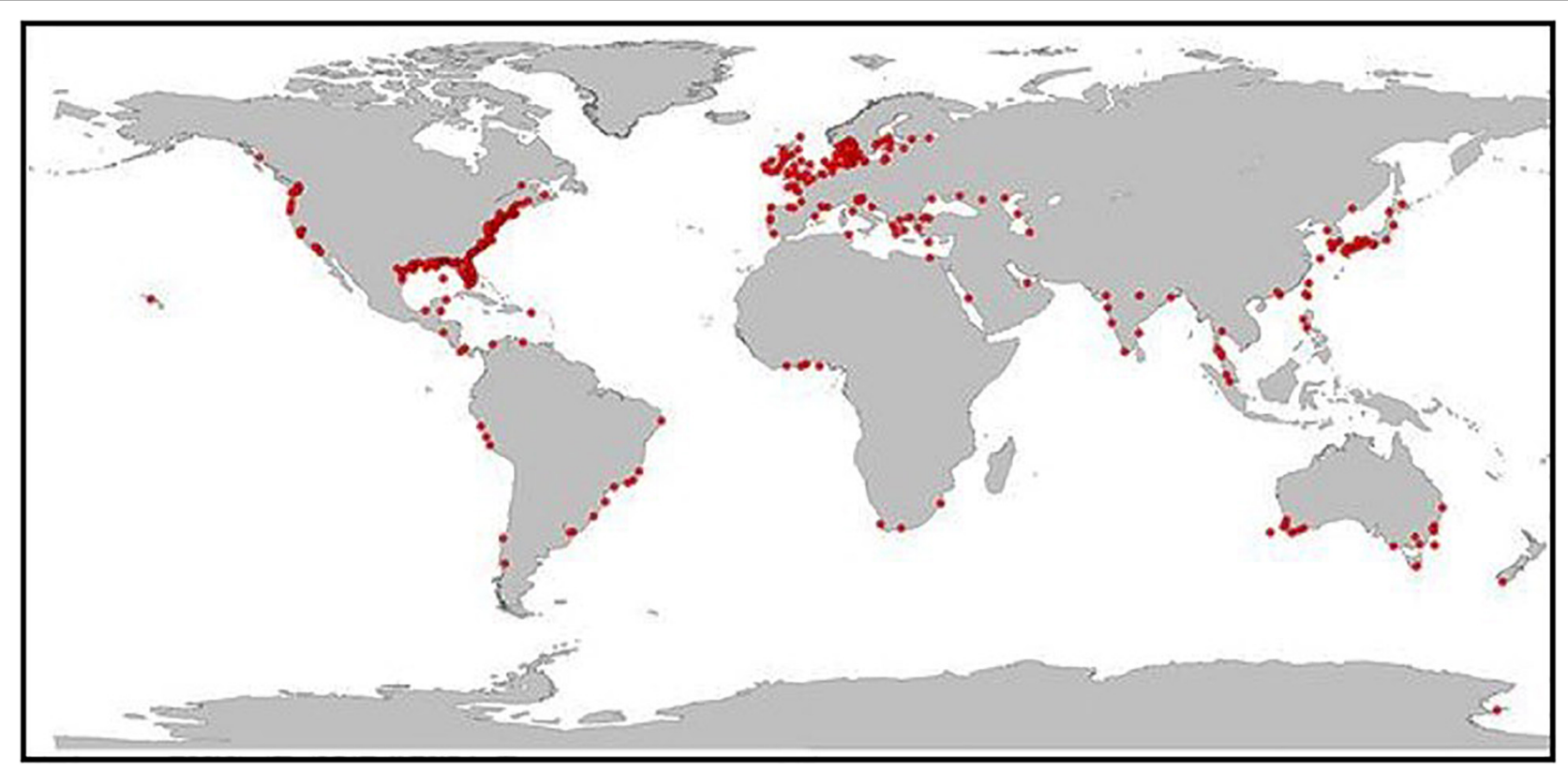

FIGURE 2 | Global distribution of eutrophic coastal marine ecosystems (adapted from Breitburg et al., 2018). Recent coastal surveys by the United States and the European Union found that $78 \%$ of U.S coastal waters and 65\% of Europe's Atlantic coastal waters exhibit symptoms of eutrophication.

(6\%) (Lu and Tian, 2017). Volatilization of ammonia from agriculture fields emits an estimated $10 \times 10^{9} \mathrm{~kg} \mathrm{~N} \mathrm{yr}^{-1}$ ( $8 \%$ of the $\mathrm{N}$ applied) into the atmosphere (Vitousek et al., 1997; Bouwman et al., 2013). (ii) Combustion of Fossil Fuels - Emissions from the combustion of fossil fuels release an estimated 25-40 $\times$ $10^{9} \mathrm{~kg} \mathrm{~N} \mathrm{yr}^{-1}$ (Penuelas et al., 2013) with Asia, Europe, North America and Sub-Saharan Africa accounting for 
$30,20,17$, and $12 \%$ of emissions, respectively (Lamsal et al., 2011). As well as being a pressure for eutrophication, nitrous oxide is a potent greenhouse gas (Davidson, 2009).

(iii) Legume Agriculture - Industrial agricultural has replaced large areas of natural vegetation with monocultures of legumes (e.g., soybeans) that support symbiotic $\mathrm{N}_{2}$-fixing bacteria. As a result, inputs of $\mathrm{N}$ from biological $\mathrm{N}$-fixation to coastal watersheds has increased from negligible to $\sim 33 \times 10^{9} \mathrm{~kg} \mathrm{yr}^{-1}$ (Boyer and Howarth, 2008).

(iv) Animal Husbandry - The production of manure has increased rapidly over the last century. Today, agriculture is responsible for over $75 \%$ of the $\mathrm{NH}_{3}$ emissions in the United States and Canada, with animal production accounting for $>70 \%$ (Aneja et al., 2001; Bittman and Mikkelsen, 2009). Current loads of manure- $\mathrm{N}$ are estimated to be $\sim 18 \times 10^{9} \mathrm{~kg} \mathrm{~N} \mathrm{yr}^{-1}$, with production hotspots in western Europe, India, northeastern China, and southeastern Australia where emissions to the atmosphere are growing rapidly (Penuelas et al., 2013; Zhang et al., 2017).

(v) Wastewater - Globally, $80 \%$ of municipal wastewater is released into the environment untreated (World Water Assessment Programme [WWAP], 2017). The percentage of treated sewage varies regionally from $90 \%$ in North America, 66\% in Europe, 35\% in Asia, 14\% in Latin America and the Caribbean, and $<1 \%$ in Africa (Selman and Greenhalgh, 2010). Thus, the most prevalent urban source of nutrient pressure is human sewage, which is estimated to have released $\sim 9 \times 10^{9} \mathrm{~kg} \mathrm{~N} \mathrm{yr}^{-1}$ into the environment in 2018 (extrapolated from van Drecht et al., 2009).

(vi) Finfish aquaculture - Annual nutrients inputs to the coastal ocean via finfish aquaculture increased worldwide by a factor of 6 from $\sim 0.43 \times 10^{9} \mathrm{~kg} \mathrm{~N} \mathrm{yr}^{-1}$ in 1985 to $2.60 \times 10^{9} \mathrm{~kg} \mathrm{~N} \mathrm{yr}^{-1}$ in 2005 (Strain and Hargrave, 2005). In contrast, the pressure of nutrient enrichment from bivalve aquaculture is generally small to negligible. In fact, bivalve aquaculture is increasingly being used to offset anthropogenic nutrient pressures (Burkholder and Shumway, 2011; Gallardi, 2014).

Globally, nonpoint (diffuse) source inputs (i-iv above) total $\sim 200 \times 10^{9} \mathrm{~kg} \mathrm{~N} \mathrm{yr}^{-1}$ and far exceed point source inputs (vvi above) of $\sim 10 \times 10^{9} \mathrm{~kg} \mathrm{~N} \mathrm{yr}^{-1}$ or $5 \%$ of the total. Thus, our emphasis here is on inputs from diffuse sources.

\section{Transport Routes}

River runoff and atmospheric deposition account for most anthropogenic $\mathrm{N}$ inputs to coastal ecosystems (Figure 3; Howarth et al., 1996; Green et al., 2004; Howarth, 2008; Jickells et al., 2017) $)^{12}$. During the twentieth Century, total riverine inputs of $\mathrm{N}$ to the coastal ocean increased from $\sim 27 \times 10^{9} \mathrm{~kg} \mathrm{~N} \mathrm{yr}^{-1}$

\footnotetext{
${ }^{12}$ Ground water discharge is estimated to be $<4 \%$ of nutrient exports to coastal waters globally (Beusen et al., 2013). Given this, and challenges of quantifying ground water inputs on regional to global scales (National Research Council [NRC], 2000), this pathway is not considered here.
}

to $\sim 48 \times 10^{9} \mathrm{~kg} \mathrm{~N} \mathrm{yr}^{-1}$ (Galloway et al., 2004; Beusen et al., 2016). Globally, there is a significant linear correlation between net anthropogenic $\mathrm{N}$ inputs to coastal watersheds and total river borne $\mathrm{N}$ export to the coastal ocean (Boyer and Howarth, 2008; Swaney et al., 2012), and we estimate that 24\% of anthropogenic $\mathrm{N}$ inputs to coastal watersheds reaches coastal ecosystems.

Anthropogenic inputs of $\mathrm{N}$ to the atmosphere are derived from the volatilization of $\mathrm{NH}_{3}$ from fertilizer and the combustion of fossil fuels (emission of nitrous oxide). Atmospheric deposition of $\mathrm{N}$ to the global ocean increased rapidly during the twentieth Century from a pre-industrial rate of $\sim 22 \times$ $10^{9} \mathrm{~kg} \mathrm{~N} \mathrm{yr}^{-1}$ to $>45 \times 10^{9} \mathrm{~kg} \mathrm{~N} \mathrm{yr}^{-1}$ today (Dentener et al., 2006; Duce et al., 2008). Of this, it is estimated that atmospheric deposition directly to the coastal ocean is on the order of $8 \times 10^{9} \mathrm{~kg} \mathrm{~N} \mathrm{yr}^{-1}$ (Seitzinger et al., 2010; Ngatia et al., 2019 ), or about $14 \%$ of total anthropogenic inputs to the coastal ocean. However, the relative magnitude of direct atmospheric deposition to coastal ecosystems varies from $\sim 5 \%$ in waters most heavily impacted by river borne inputs (e.g., the northern Gulf of Mexico) to $\geq 30 \%$ in waters with relatively low river borne inputs (e.g., Baltic, western Mediterranean, mid-Atlantic and northeast U.S.-Canadian Atlantic coastal regions) (Paerl et al., 2002; Spokes and Jickells, 2005).

\section{PATTERNS AND TRENDS WITHIN ECOSYSTEMS}

For comparative purposes, we have selected a set of coastal ecosystems that have been impacted by anthropogenic nutrient loading: three open continental shelf ecosystems (northern Gulf of Mexico, East China Sea, and the Great Barrier Reef), three semi-enclosed ecosystems (Baltic Sea, Northern Adriatic Sea, and Chesapeake Bay), and one eastern boundary upwelling system (Santa Barbara Channel in the California Current system). As a group they are subject to a wide range of $\mathrm{N}$ inputs (0.07-2.0 $\left.\times 10^{9} \mathrm{~kg} \mathrm{~N} \mathrm{yr}^{-1}\right)$ and exhibit contrasting capacities to minimize or amplify the effects of anthropogenic nutrient enrichment. Sufficient data and information on anthropogenic nutrient loadings and their impacts for all of these systems have been collected over long enough periods (decades) to parse major pressures, impacts and trends. All seven ecosystems exhibit a range of eutrophic states as indicated by levels of phytoplankton production $^{13}$ (Table 1), and, with the exception of the Great Barrier Reef, all are in the northern hemisphere (Figure 2).

\section{Pressures and Changes in States Northern Gulf of Mexico (NGM)}

The NGM (continental shelf off the states of Louisiana, and Texas) has an area of $\sim 60,000 \mathrm{~km}^{2}$ with depths $<200 \mathrm{~m}$. The Mississippi-Atchafalaya River system is the primary source of fresh water $(\sim 80 \%)$ and new ${ }^{14}$ nutrients $(\sim 90 \%)$ to the NGM.

\footnotetext{
${ }^{13}$ Oligotrophic $<100 \mathrm{~g} \mathrm{C} \mathrm{m}^{-2} \mathrm{yr}^{-1}$, Mesotrophic 100-300 g C m${ }^{-2} \mathrm{yr}^{-1}$, Eutrophic 301-500 $\mathrm{g} \mathrm{C} \mathrm{m}^{-2} \mathrm{yr}^{-1}$, and Hypereutrophic $>500 \mathrm{~g} \mathrm{C} \mathrm{m}^{-2} \mathrm{yr}^{-1}$.

${ }^{14}$ Nutrients supplied from outside the ecosystem (e.g., nitrate input via upwelling and river runoff) as opposed to nutrients that are regenerated and recycled within the ecosystem (e.g., ammonium).
} 


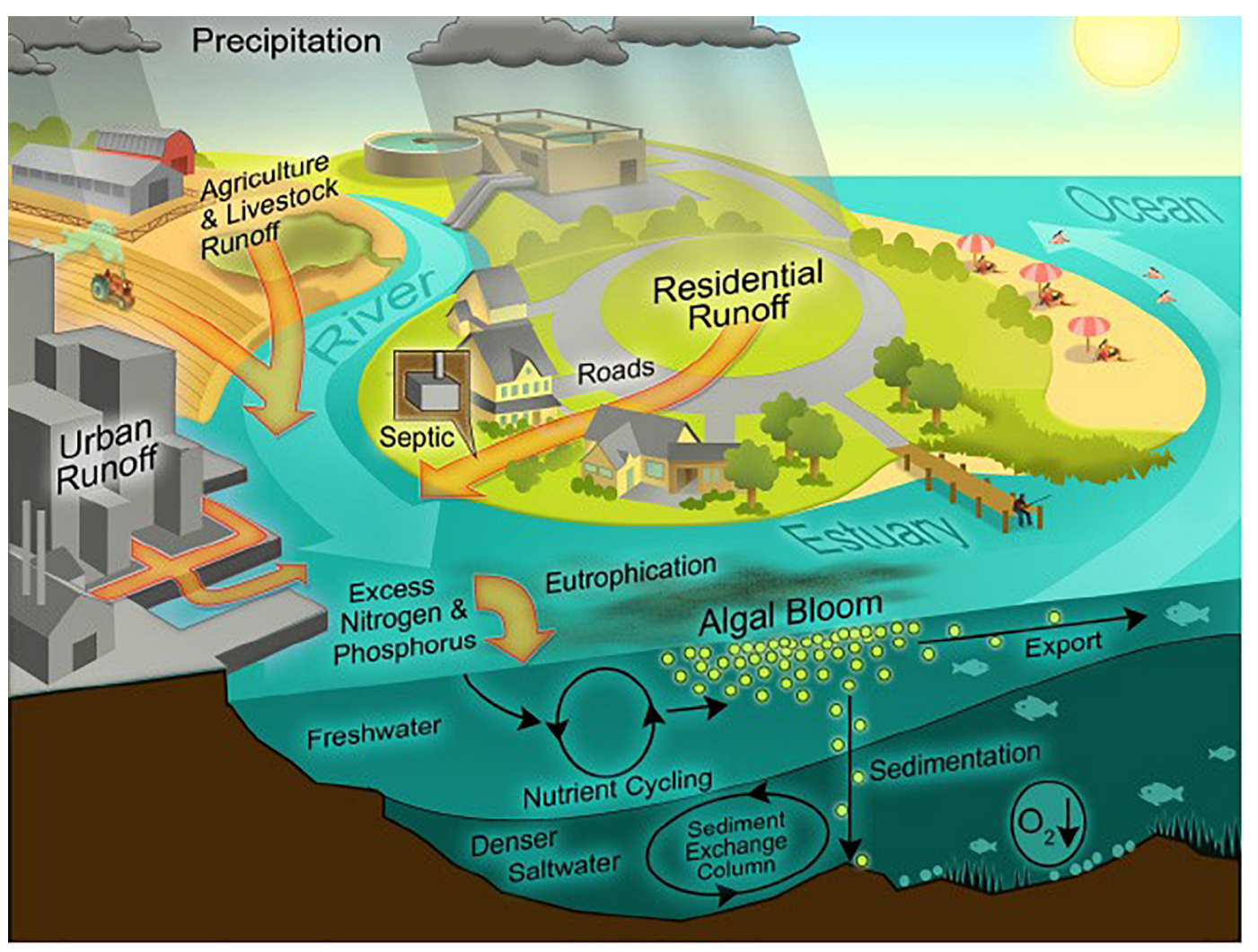

FIGURE 3 | Nutrient enrichment pathways () via river runoff, storm water runoff (Urban and Residential Runoff) and atmospheric precipitation; and effects of anthropogenic nutrient enrichment on phytoplankton biomass (Algal Bloom) and consequences of eutrophication, e.g., oxygen depletion of bottom waters $\left(\mathrm{O}_{2} \downarrow\right)$ (Source: Hans Paerl, University of North Carolina).

TABLE 1 | Characteristics of the seven ecosystems (NGM - Northern Gulf of Mexico, ECS - East China Sea, GBR - Great Barrier Reef, BS - Baltic Sea, NA - Northern Adriatic Sea, CB - Chesapeake Bay, Santa Barbara Channel - SBC) compared in terms of ecosystem-surface area $\left(\times 10^{3} \mathrm{~km}^{2}\right)$, mean DIN load (10 $\left.\mathrm{kg} \mathrm{N} \mathrm{yr}^{-1}\right)$, mean $\mathrm{NPP}\left(\mathrm{g} \mathrm{C} \mathrm{m}^{-2} \mathrm{yr}^{-1}\right.$ ), residence time (months), dilution potential (surface area $\times 1000 \div \mathrm{N}$ load), spatial extent of bottom water hypoxia as a percent of ecosystem area, and the frequency of toxic algal events ( $x$ - low, $x x$ - moderate, $x x x-$ high).

\begin{tabular}{|c|c|c|c|c|c|c|c|c|}
\hline & Area & N Load & Phytoplankton NPP & Residencetime & Dilutionpotential & Hypoxia & Toxic events & Rank \\
\hline NGM & 160 & 1.3 & $260^{a}$ & 2.5 & 0.12 & 25 & $x x$ & 4 \\
\hline ECS & 750 & 2.0 & $160^{b}$ & 16 & 0.37 & 15 & $x x x$ & 6 \\
\hline GBR & 344 & 0.08 & $114^{C}$ & 1 & 4.30 & 0 & $p$ & 7 \\
\hline BS & 350 & 0.64 & $120^{d}$ & $>360$ & 0.65 & 19 & $x$ & 2 \\
\hline NA & 19 & 0.26 & $140^{e}$ & 5.5 & 0.07 & $<10$ & $x x x$ & 3 \\
\hline CB & 12 & 0.07 & $320^{f}$ & 7 & 0.17 & 40 & $x$ & 1 \\
\hline SBC & 4 & 0.21 & $490^{g}$ & 12 & 0.02 & 20 & $x x$ & 5 \\
\hline
\end{tabular}

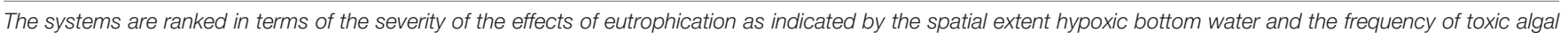

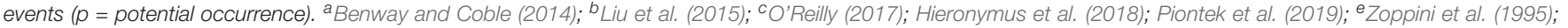
Hopkins (1999); Pugnetti et al. (2005, 2006); ${ }^{f}$ Harding et al. (2020); ${ }^{g}$ Brzezinski and Washburn (2011).

Volume transports of the river system range between 220 and $630 \mathrm{~km}^{3} \mathrm{yr}^{-1}$ with a mean of $530 \mathrm{~km}^{3} \mathrm{yr}^{-1}$ (Aulenbach et al., 2007). Depending on river discharge, the spatial extent of the resulting buoyant, nutrient-rich coastal plume varies from 10,000 to $35,000 \mathrm{~km}^{2}$ with a maximum seasonal extent typically during May-June $5^{15}$. On average, the river-system delivers $\sim 1.3 \times 10^{9} \mathrm{~kg}$

${ }^{15} \mathrm{http} / / /$ mississippiriverdelta.org/files/2018/09/Known-Impacts- of- theMississippi-River-1.pdf (Accessed April 21, 2020).
$\mathrm{N} \mathrm{yr}^{-1}$ (Dunn, 1996; Turner et al., 2007). Discharge is lowest on average during September-October and highest during MarchApril (Dunn, 1996; Dagg and Breed, 2003; Turner et al., 2007). Of this input, it is estimated that denitrification and anammox ${ }^{16}$ remove $40-50 \%$ of nitrate inputs annually (Seitzinger and Giblin,

${ }^{16}$ Denitrification is generally the dominant pathway for $\mathrm{N}$ removal in coastal ecosystems (Dalsgaard et al., 2005).Coastal marine sediments play a critical role in $\mathrm{N}$ losses via denitrification and anaerobic ammonium oxidation (anammox). 
1996). Direct atmospheric deposition of DIN to the NGM is small $(<1 \%)$ in comparison (Goolsby et al., 1999).

Riverine inputs of nitrate ${ }^{17}$ have increased by at least threefold since WW II, with most of this increase occurring between 1970 and 1983 due to increased use of nitrogen fertilizers in the river's large watershed (Goolsby et al., 1999). Since 1983, annual riverine inputs of DIN have fluctuated between $\sim 0.6 \times 10^{9} \mathrm{~kg} \mathrm{yr}^{-1}$ in 2000 and $\sim 1.8 \times 10^{9} \mathrm{~kg} \mathrm{yr}^{-1}$ in 1993 . In contrast to $\mathrm{N}$, there has been relatively little change in $\mathrm{P}$ discharge by the Mississippi over a similar period so that the N:P ratio of the dissolved nutrient pool is consistently above the Redfield molar ratio of 16 (Redfield, 1958).

Phytoplankton biomass is correlated with the riverine supply of N (Fennel et al., 2011), and the annual cycle of phytoplankton biomass is characterized by a spring maximum and an autumn minimum (Bode and Dortch, 1996; Gomez et al., 2018). Spatially, phytoplankton biomass and NPP vary with salinity as follows (Lohrenz et al., 1997, 1999; Dagg and Breed, 2003; Gomez et al., 2018):

- Near field (oligohaline) where salinity is $<18$, phytoplankton biomass is $\leq 5 \mu \mathrm{g}$ Chl liter ${ }^{-1}$, and phytoplankton NPP is $\leq 1 \mathrm{~g} \mathrm{C} \mathrm{m}^{-2} \mathrm{~d}^{-1}$;

- Mid field (mesohaline) where salinity is 18-32, phytoplankton biomass is 3-50 $\mu \mathrm{g}$ Chl liter ${ }^{-1}$, and phytoplankton NPP is $0.5-13 \mathrm{~g} \mathrm{C} \mathrm{m}^{-2} \mathrm{~d}^{-1}$;

- Far field (polyhaline) where salinity is $>32$, phytoplankton biomass is $0.1-10 \mu \mathrm{g}$ Chl liter ${ }^{-1}$, and phytoplankton NPP is $\left.0.2-3 \mathrm{~g} \mathrm{C} \mathrm{m}^{-2} \mathrm{~d}^{-1}\right)$.

The spring bloom in the mesohaline fuels the development of an extensive hypoxic zone that is generally confined to a relatively thin (1-4 m) bottom boundary layer over the inner shelf from March to October (Dagg et al., 2007; Justić et al., 2007; Fennel and Testa, 2019). Seasonal hypoxia began expanding in the $1950 \mathrm{~s}$ with rapid increases in the time-space extent of hypoxia during the 1970s (Rabalais and Turner, 2019). The spatial extent of hypoxia over the shelf has varied between $<5,000 \mathrm{~km}^{2}$ in 2000 and $22,720 \mathrm{~km}^{2}$ in 2017 with a mean of $13,700 \mathrm{~km}^{2}$ making it one of the largest open shelf hypoxic zone in the world (Rabalais and Turner, 2019; Figure 4). Seasonal hypoxia has resulted in losses of benthic biodiversity and biomass as longer-lived species are eliminated (Committee on Environment and Natural Resources [CENR], 2000; Rabalais and Turner, 2019).

In addition to bottom water hypoxia, increases in nutrient loading appears to be promoting the growth of potentially toxic phytoplankton. The dinoflagellate Karenia brevis is the primary toxic species in the NGM where it is ubiquitous at background levels of $<1$ cell ml$~^{-1}$ (Steidinger et al., 1998). Blooms of $K$. brevis (>10 cells $\mathrm{ml}^{-1}$ ) occur almost annually off the west coast of Florida, but historically have occurred less frequently along the Texas coast (Hetland and Campbell, 2007). The abundance of Pseudo-nitzschia spp. has increased over the shelf since the 1950s, a trend that may be related to the long-term increase in nutrient loading (Dortch et al., 1997; Parsons and Dortch, 2002;

${ }^{17}$ Human activity preferentially mobilizes nitrate over other forms of nitrogen (Howarth et al., 1996).
Baustian et al., 2016). Peaks in the abundance of potentially toxinproducing dinoflagellates (Dinophysis spp. and Prorocentrum spp.) have been observed to develop in concert with the spring peak in river flow (Bargu et al., 2016).

\section{East China Sea (ECS)}

The ECS has an area of $\sim 750,000 \mathrm{~km}^{2}, 75 \%$ of which is $<200$ $\mathrm{m}$ deep. With a mean volume transport of $\sim 900 \mathrm{~km}^{3} \mathrm{yr}^{-1}$ (Liu et al., 2003), the Changjiang (Yangtze) River accounts for $>90 \%$ of river runoff and is the largest source of nutrient loadings to the ECS (Yan et al., 2010; Wu et al., 2011; Tong et al., 2015). The annual cycle of flow is characterized by a summer maximum and a winter minimum (Chen et al., 2016). Under high summer flows, the River's coastal plume spreads eastward over an area that can cover as much as $30 \%$ of the ECS in contrast to the winter low flow period when the plume is confined to a narrow band along the coast south of the River's mouth (Dong et al., 2010; Tong et al., 2015).

Riverine inputs of $\mathrm{N}$ have been increasing since the $1960 \mathrm{~s}$ (Zhou et al., 2008; Chen et al., 2019). Despite the Three Gorges Dam, which began storing water in 2013, inputs of DIN from the Changjiang increased by nearly an order of magnitude from $0.220 \times 10^{9} \mathrm{~kg} \mathrm{~N} \mathrm{yr}^{-1}$ in 1970 to $2.0 \times 10^{9} \mathrm{~kg} \mathrm{~N} \mathrm{yr}^{-1}$ in 2012 (Tong et al., 2015; Lin et al., 2017; Strokal et al., 2020). N-fixation contributes only $\sim 0.013 \times 10^{9} \mathrm{~kg} \mathrm{~N} \mathrm{yr}^{-1}$ or $<1 \%$ of riverine inputs (Zhang R. et al., 2012). Losses of $\mathrm{N}$ via denitrification and anammox are estimated to be equivalent to riverine inputs of anthropogenic DIN (Lin et al., 2017). At the same time, the dam has reduced the mass transport of suspended matter and, therefore, the input of P to the ECS (Xu et al., 2015). As a consequence, N:P molar ratios have increased to $>100$ (Huang et al., 2019).

Dissolved nutrients are also delivered to the ECS by the Taiwan Warm Current (TWC), the Kuroshio, and atmospheric deposition (Chen, 1996, 2008; Zhang et al., 2019). Atmospheric deposition of $\mathrm{N}$ directly to the ECS in 2012 is estimated to have been $\sim 80 \%$ of riverine inputs. Eutrophication caused by nutrient inputs from the Changjiang are most pronounced in the near field plume (salinity < 30) over the inner shelf $(0-50 \mathrm{~m})$ while inputs from the TWC dominate the mid-field (salinity 31-32) over the mid-shelf (50-100 m) and inputs from the Kuroshio dominate the far field (salinity > 32) over the outer shelf $(100-200 \mathrm{~m})$ (Wang et al., 2014). Atmospheric deposition is distributed over the entire ECS (Zhang et al., 2019).

The annual cycle of NPP is characterized by a summer maximum and a winter minimum. Interannual variations (19982007) in the spatial extent of high $\mathrm{Chl}$ are driven by variations in river discharge (Xiuren et al., 1988; Kim et al., 2009). Increases in discharge have led to increases in NPP, increases in the abundance of small phytoplankton $(<20 \mu \mathrm{m})$ and dinoflagellates, and decreases in diatoms in the coastal plume (Zhou et al., 2008; Li et al., 2019). While an interannual trend in Chl for the ECS as a whole (1996-2014) is not apparent (O'Reilly, 2017), $\mathrm{Chl}$ levels in the coastal plume have increased as anthropogenic nutrient inputs increased while $\mathrm{Chl}$ in the far field decreased due to increases in vertical stratification as the upper ocean warms (Kong et al., 2019). As the plume spreads and mixes with 


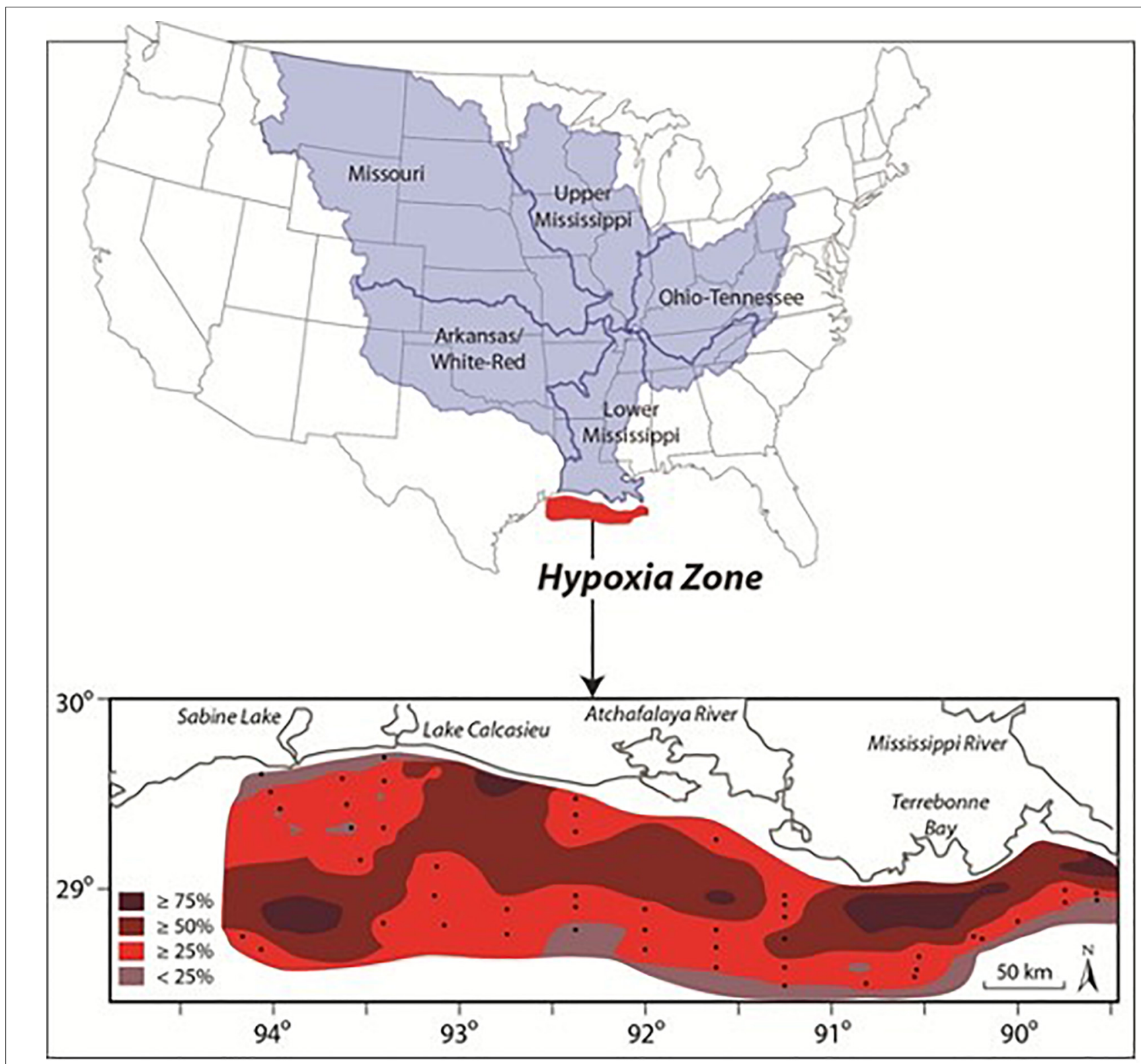

FIGURE 4 | Mississippi-Atchafalaya River Basin and the frequency (percent occurrence) of mid-summer bottom-water hypoxia off the coast of Louisiana and Texas during 1985-2008 (inset) (Source: Center for Agricultural and Rural Development, lowa State University).

open shelf water, $\mathrm{Chl}$ concentrations decline from high levels $\left(>10 \mathrm{mg} \mathrm{m}^{-3}\right)$ in the plume to low levels $\left(<0.5 \mathrm{mg} \mathrm{m}^{-3}\right)$ in oligotrophic open shelf waters, a pattern that is driven by the riverine supply of nutrients (Wang and Wang, 2007; Chen, 2008; Mackey et al., 2017).

NPP in the plume is the primary source of particulate organic matter to the ECS (Zuo et al., 2016). As the Changjiang plume flows over ambient ocean water and the surface layer warms, the water column becomes increasingly stratified and this supply of organic matter fuels bacterial oxygen demand causing bottom waters to become hypoxic (Rabouille et al., 2008; Liu et al., 2015; Wang et al., 2016;
Zuo et al., 2016; Qian et al., 2107). Persistent summer hypoxia causes high mortality rates among sessile benthic species and reduces recruitment to economically important fish populations (Levin et al., 2009).

Hypoxia was first reported in 1959 (Zhu et al., 2011). Interannual increases in NPP has led to increases in the spatial extent of bottom water hypoxia over the inner shelf from $\sim 1,800$ $\mathrm{km}^{2}$ in 1959 to $\sim 13,700 \mathrm{~km}^{2}$ in 1999 and $>15,400 \mathrm{~km}^{2}$ in 2006 (Levin et al., 2009; Li et al., 2011; Wang et al., 2015; Qian et al., 2107), a trend that has been attributed to elevated nutrient inputs due to fertilizer use in the Changjiang watershed (Wu et al., 2019). Bottom water hypoxia now covers $>15 \%$ of the ECS making it 
one of the largest coastal hypoxic zones in the world (Chen et al., 2007; Wang et al., 2016; Zhu et al., 2016).

Intrusions of nutrient-rich oceanic water from the Kuroshio also contribute to the development of hypoxia. The hypoxic region north of $30^{\circ} \mathrm{N}$ is dominated by Changjiang inputs, with its $\mathrm{N}$ loads supporting $74 \%$ of oxygen consumption; south of $30^{\circ} \mathrm{N}$, oceanic nitrogen sources become more important, supporting $39 \%$ of oxygen consumption during the hypoxic season, but the Changjiang remains the main control on hypoxia formation also in this region (Große et al., 2020). The importance of oceanic nutrient supply distinguishes hypoxia in the ECS from the otherwise comparable situation in the NGM, where a similar spatial extent of hypoxia is fueled by riverine inputs of anthropogenic nutrients from the Mississippi-Atchafalaya River system (Fennel and Testa, 2019).

In addition to the impacts of hypoxia, increases in the N:P molar ratio promote blooms of toxic dinoflagellates (Glibert et al., 2018; Huang et al., 2019). Reported toxic algal events along the coast increased from undetected in the 1950s and 60 s to 10 in the 70s, 25 in the 80s, and > 100 in the 90s (Yan et al., 2002). During 2000-2006, the trend continued with most events occurring during summer (Yan et al., 2010) in Zhejiang coastal waters, particularly in the Zhoushan Archipelago which is home to the largest marine fishery in China (Wang and Wu, 2009). Particularly, large scale blooms (covering an area $>1,000 \mathrm{~km}^{2}$ ) have been recorded every year since 1998, and the dinoflagellate Prorocentrum donghaiense has become the recurrent bloom species for more than 10 years (Li et al., 2014; Lu et al., 2014). Blooms of other potentially toxic dinoflagellates (Karodinium veneficum, Karenia mikimotoi, $K$. veneficum, Alexandrium tamarense, A. catenella, and Heterosigma akashiwo) have also been observed (Lu et al., 2014; Zhou et al., 2015; Wang Y.-F. et al., 2018). Toxic dinoflagellate blooms have resulted in millions of dollars of lost fish landings (Tang et al., 2006; Zhou et al., 2008; Li et al., 2014; Mackey et al., 2017; Glibert et al., 2018; Wang R. et al., 2018; Chen et al., 2019).

Eutrophication may also be an important factor contributing to increases in jellyfish abundance and blooms (Mills, 2001; Purcell et al., 2007; Diaz and Rosenberg, 2008; Richardson et al., 2009; Dong et al., 2010; Condon et al., 2011; Brotz et al., 2012; Boero et al., 2016). Three jellyfish species (Aurelia aurita, Cyanea nozakii, and Nemopilema nomurai) form large blooms, the frequency of which has been increasing since the 1950s (Dong et al., 2010; Brotz et al., 2012). N. nomurai, the giant jellyfish, is arguably the most serious threat to fisheries since it is most abundant in the Changjiang plume where it preys on juvenile fish (Sun et al., 2015).

\section{Great Barrier Reef (GBR)}

With a surface area of $344,000 \mathrm{~km}^{2}$ and depths of $<50 \mathrm{~m}$, Australia's GBR is the Earth's largest reef system. As the reef developed over the last 20,000 years on the continental shelf, it formed a large coastal lagoon $(<40 \mathrm{~m}$ deep) into which rivers discharge from 35 watersheds (total mean discharge of 70 $\mathrm{km}^{3} \mathrm{yr}^{-1}$ ). Today, rivers are the largest single source of new nutrients to the lagoon (Furnas et al., 1997; Brodie et al., 2011, 2012; Devlin et al., 2015), and elevated nutrient concentrations are measurable at distances of hundreds of kilometers from river mouths (Devlin and Brodie, 2005). Riverine inputs are characterized by episodic peaks in flow with most volume transport occurring during November-April when large flow events are most frequent and $>90 \%$ of land-based nutrient inputs occurs (Brodie et al., 2011).

Since European settlement, annual riverine inputs of $\mathrm{N}$ and $\mathrm{P}$ to the lagoon have increased from $\sim 0.014 \times 10^{9} \mathrm{~kg} \mathrm{~N} \mathrm{yr}^{-1}$ to $0.080 \times 10^{9} \mathrm{~kg} \mathrm{~N} \mathrm{yr}^{-1}$ and from $1.8 \times 10^{6} \mathrm{~kg} \mathrm{P} \mathrm{yr}^{-1}$ to $16 \times$ $10^{6} \mathrm{~kg} \mathrm{P} \mathrm{yr}^{-1}$ (Brodie et al., 2009; Kroon et al., 2012). The form of $\mathrm{N}$ delivered has also changed from predominantly dissolved organic nitrogen (DON) to predominantly DIN (Harris, 2001; Brodie and Mitchell, 2005). In addition to riverine inputs, $\mathrm{N}$-fixation supplies $0.01-0.21 \times 10^{9} \mathrm{~kg} \mathrm{~N} \mathrm{y}^{-1}$, rainfall $2.7 \times$ $10^{6} \mathrm{~kg} \mathrm{~N} \mathrm{y}^{-1}$, and upwelling 0.001-0.004 $\times 10^{9} \mathrm{~kg} \mathrm{~N} \mathrm{y}^{-1}$ (Furnas et al., 1997, 2011; Benthuysen et al., 2016). Export via denitrification is estimated to be in the range of $0.016-0.024 \times$ $10^{9} \mathrm{~kg} \mathrm{~N} \mathrm{y}^{-1}$ (Furnas et al., 2011) or about $25 \%$ of total inputs.

Long-term monitoring data show that hard coral cover on the GBR has reduced by $>70 \%$ over the past century Bell et al., 2014). Waters of the lagoon become progressively more productive as they flow through the reef system, an increase that is attributed largely to benthic N-fixation (Bell et al., 2014). Current levels of nutrient enrichment support $\mathrm{Chl}$ concentrations that range from annual means of $<0.3 \mu \mathrm{g}$ liter $^{-1}$ to $0.7 \mu \mathrm{g} \mathrm{liter}^{-1}$ (Brodie et al., 2007). Under flood conditions during April-November, peaks in river discharge support phytoplankton blooms in the central and southern lagoon that yield Chl concentrations of 1$20 \mu \mathrm{g} \mathrm{liter}^{-1}$ (Devlin and Brodie, 2005; Devlin and Schaffelke, 2009; Brodie et al., 2009, 2010; McKinnon et al., 2013). Nutrientdriven increases in phytoplankton biomass and macroalgal cover have been shown to be associated with long term coral reef decline (De'ath and Fabricius, 2010; D'Angelo and Wiedenmann, 2014). Clear water ${ }^{18}$ and low macroalgal cover promote high coral species richness (De'ath and Fabricius, 2010). There is growing evidence that Acanthaster planci ${ }^{19}$ predation events and coral bleaching are exacerbated by eutrophication and that the lack of recovery of the reefs is primarily a consequence of high phytoplankton biomass (Bell et al., 2014; Allen et al., 2019). Thus, $23 \%$ of the reef system has been degraded in areas with Chl concentrations $>0.2 \mu \mathrm{g}$ liter $^{-1}$, concentrations that are considered to be indicative of eutrophication in the GBR lagoon (Bell, 1992; Bell et al., 2014). De'ath and Fabricius (2010) predict that reducing agricultural runoff could reduce macroalgal cover by $39 \%$ and increase the species richness of hard corals and phototrophic octocorals by 16 and 33\%, respectively.

$\mathrm{N}: \mathrm{P}$ ratios are consistently $<16$ and many processes in coral reefs are nitrogen limited (Furnas et al., 2005), and

\footnotetext{
${ }^{18}$ Increases in $\mathrm{Chl}$ reduce light penetration. Clear water occurs when the attenuation coefficient for downwelling photosynthetically active radiation is $<0.17$.

${ }^{19}$ The crown-of-thorns (Acanthaster planci) is responsible for the loss of immense stretches of coral throughout the Indo-Pacific region, especially on the GBR. Larvae of this starfish are able to clone themselves, and the frequency of larval cloning increases with increasing phytoplankton biomass. This has the potential to increase the supply of larvae and consequently the abundance of adults (Allen et al., 2019).
} 
increases in river-borne inputs of $\mathrm{P}$ have promoted the growth of Trichodesmium spp. and other $\mathrm{N}$-fixing organisms that introduce new $\mathrm{N}$ into the lagoon-reef system at rates that are far higher now than in the past (Bell and Elmetri, 1995; Bell et al., 1999; Messer et al., 2017; Blondeau-Patissier et al., 2018). This additional input of new $\mathrm{N}$ appears to be enhancing increases in phytoplankton biomass above that expected based on riverine inputs of $\mathrm{N}$ alone, and there is evidence that this is a significant factor in the demise of fringing reefs in the inner GBR lagoon (Bell and Elmetri, 1995; Brown et al., 2018). In addition, blooms of Trichodesmium spp. are known to be a source of ciguatera in the ciguatera food chain ${ }^{20}$ (Kerbrat et al., 2011), and several genera of potentially toxic dinoflagellates have also become abundant in the lagoon (Gambierdiscus, Prorocentrum and Ostreopsis), a trend that may be driven by the ongoing eutrophication of the lagoon (Skinner et al., 2013).

\section{Baltic Sea (BS)}

The BS has an area of $420,000 \mathrm{~km}^{2}$ with a basin that has a mean depth of $\sim 54 \mathrm{~m}$, a number of sub-basins ( $>150 \mathrm{~m}$ deep), and a shallow sill $(<20 \mathrm{~m})$ in the Danish Straits separating it from the North Sea and Atlantic Ocean. Of the 250 rivers flowing into the Baltic, seven account for $\sim 45 \%$ of the total flow $\left(\sim 455 \mathrm{~km}^{3}\right.$ $\mathrm{yr}^{-1}$ ) (HELCOM, 2011), most of which occurs in the eastern BS. As a consequence, surface salinity gradually increases from 2 to 4 in the northeastern Gulf of Bothnia between Sweden and Finland to 18-26 in the southwestern Kattegat between Denmark and Sweden (Gustafsson and Westman, 2002; Elmgren et al., 2015). In winter, the water column is mixed down to a permanent halocline $(40-80 \mathrm{~m})$. In summer, a seasonal thermocline forms above the permanent halocline and a three-layered structure develops with a warm and low salinity surface layer, a higher salinity intermediate layer of cold water, and an oxygen depleted bottom layer of warmer and saltier water (Liblik and Lips, 2019).

Rivers account for $\sim 70 \%$ of anthropogenic nutrient inputs to the Baltic, and concentrations of DIN are highest in coastal waters from the Belt Sea in the southwest to the Gulfs of Finland and Bothnia to the northeast (HELCOM, 2018a; Sonesten et al., 2018). Flow generally peaks during April-June and is relatively low during August-January (Hordoir and Meier, 2010). Nutrient inputs were high during 1995-2002 $\left(0.65-0.90 \times 10^{9} \mathrm{~kg} \mathrm{~N} \mathrm{yr}^{-1}\right.$ and 33-43 $\left.\times 10^{6} \mathrm{~kg} \mathrm{P} \mathrm{yr}^{-1}\right)$ compared to 2003-2015 (0.50-0.78 $\times 10^{9} \mathrm{~kg} \mathrm{~N} \mathrm{yr}^{-1}$ and $\left.22-35 \times 10^{6} \mathrm{~kg} \mathrm{P} \mathrm{yr}^{-1}\right) . \mathrm{N}$ input via $\mathrm{N}$-fixation by cyanobacteria is estimated to be $\sim 0.40 \times 10^{9} \mathrm{~kg} \mathrm{~N}$ $\mathrm{yr}^{-1}$ (Olofsson et al., 2020), nearly equivalent to riverine inputs. Atmospheric deposition also declined during this period from $\sim 0.30 \times 10^{9} \mathrm{~kg} \mathrm{~N} \mathrm{yr}^{-1}$ in 1995 to $0.21 \times 10^{9} \mathrm{~kg} \mathrm{~N} \mathrm{yr}^{-1}$ in 2011 . Relatively low inputs via river discharge and wet precipitation during 2003-2015 were due to dry periods with low river runoff $(2003,2014,2015)$. Denitrification removes an estimated $42-96 \%$ of riverine nitrate inputs annually (Dalsgaard et al., 2013), and, over the long term, anthropogenic nutrient enrichment has led to accumulations of phosphorus $(\mathrm{P})$ in benthic sediments to an extent that internal releases of $\mathrm{P}$ to the water column under

\footnotetext{
${ }^{20}$ Ciguatera fish poisoning is a foodborne illness caused by eating reef fish whose flesh is contaminated with certain toxins (e.g., palytoxin, an intense vasoconstrictor considered to be one of the most poisonous non-protein toxins known).
}

anoxic conditions off-sets reductions in land-based inputs of anthropogenic P (Gustafsson et al., 2012).

Mean Chl concentrations remained $<1 \mu$ liter $^{-1}$ from 1880 to 1950 and increased to $2-4 \mu \mathrm{g} \mathrm{liter}^{-1}$ during 1990 2009 (Hieronymus et al., 2018). Two seasonal bloom periods characterize most of the BS, spring blooms of diatoms and dinoflagellates and cyanobacterial blooms in late summer (Spilling et al., 2018). $\mathrm{N}$ assimilation during the spring bloom leads to a low $\mathrm{N}: \mathrm{P}$ ratio during summer which favors $\mathrm{N}$-fixing cyanobacteria during warm, calm summer months (Wasmund et al., 2001, 2005). Summer cyanobacterial blooms have been intensifying since 1982, a trend that is correlated with increases in anthropogenic P loading and the magnitude of hypoxia (Pliñski et al., 2007; Funkey et al., 2014; Savchuk, 2018).

Hypoxic bottom water in the Baltic proper (Gotland SubBasin) has been present for at least the last 100 years, but increased in spatial and temporal extent over the last 3 decades (Duncombe, 2018) as the buoyancy of the surface layer above the permanent halocline increased due to increasing temperature and decreasing salinity (Liblik and Lips, 2019). During 19932016, the spatial extent of hypoxic bottom water in the main basins of the Baltic (Figure 5) increased from $~ 5,000 \mathrm{~km}^{-2}(1.3 \%$ of the Baltic) to $\sim 70,000 \mathrm{~km}^{-2}$ (19\% of the Baltic) (Jokinen et al., 2018; Limburg and Casini, 2019). At its maximum extent, the spatial extent of hypoxia is the largest anthropogenically enhanced hypoxic zone in the world (Schmale et al., 2016).

Benthic communities have been severely impacted by increases in phytoplankton biomass due to the rapid attenuation of sunlight with depth in the surface layer and hypoxia in the bottom layer (HELCOM, 2009). Impacts include the following:

- Declines of seagrasses and intertidal brown algae - The present spatial distribution of eelgrass (Zostera marina) constitutes only about $20-25 \%$ of that present in 1900 , and the depth limit of the brown macroalgal species Fucus vesiculosus has declined significantly since the 1960s.

- Decline of benthic macrofauna - Hypoxia has resulted in habitat loss and the elimination of benthic macrofauna over vast areas disrupting benthic food webs. Currently, macrobenthic communities are severely degraded and below a 40 -year average in the entire Baltic Sea. It is estimated that the missing biomass of benthic animals due to hypoxia is equivalent to $\sim 264,000$ metric tons of carbon annually which represents $\sim 30 \%$ of the Baltic's total secondary production (Diaz and Rosenberg, 2008). Thus, cod has experienced a marked decline in mean body condition (weight at a specific length) (Limburg and Casini, 2019), a trend that has made cod more susceptible to predation by seals, infections by parasites, and competition from flounder. At the same time, nutrient enrichment has enhanced the biomass of forage fish by up to $50 \%$ in some years and areas due to increased body weight (Eero et al., 2016).

- Increased abundance of $\mathrm{N}$-fixing cyanobacteria Seasonal hypoxia not only impacts aerobic benthic and pelagic animals, it also promotes increases in the abundance of N-fixing cyanobacteria (Nodularia spumigena). The 


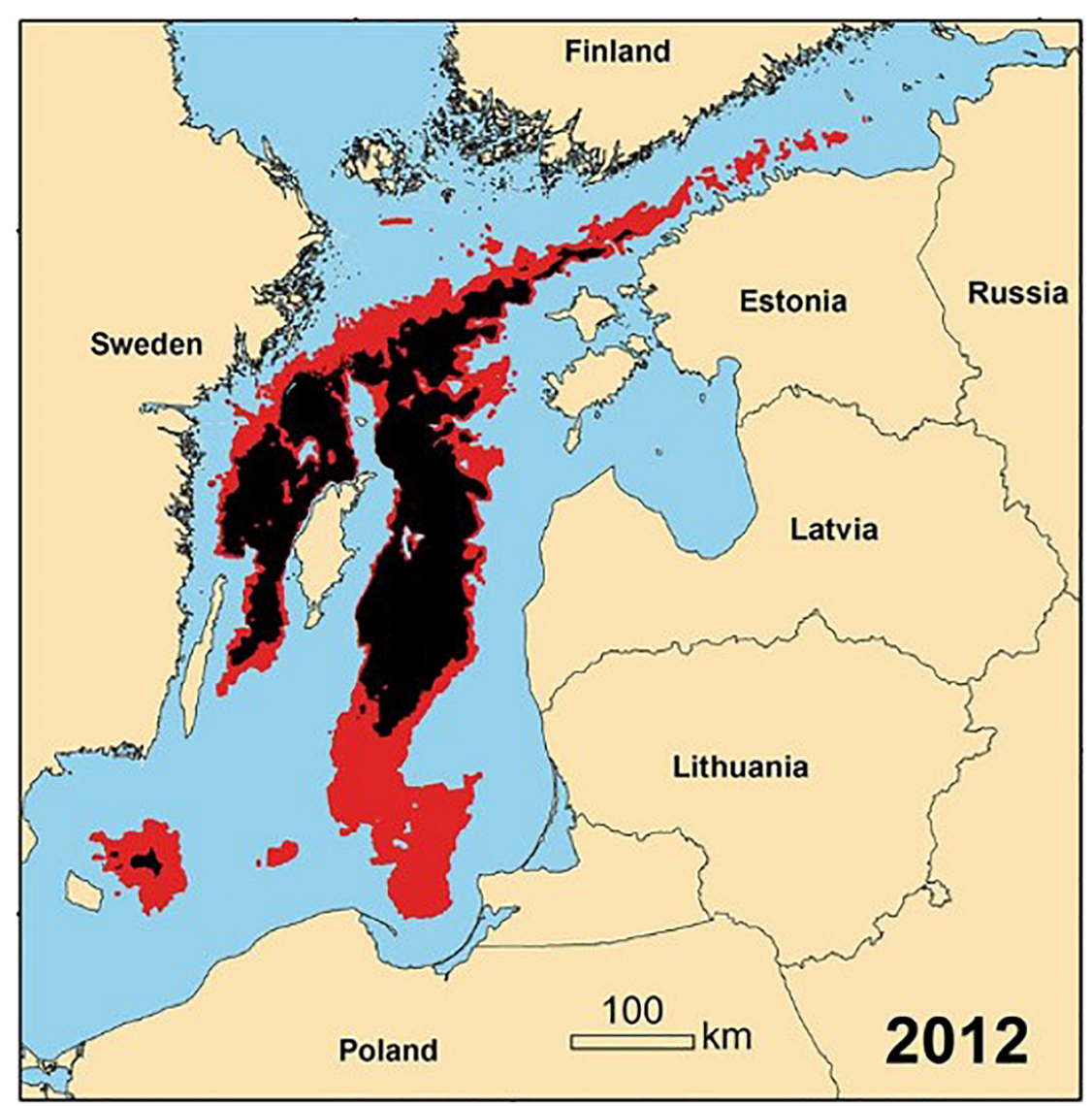

FIGURE 5 | Spatial distribution of bottom hypoxia (red) and anoxia (black) in the Baltic Sea in 2012 (annual mean modified from Carstensen et al., 2014).

enhanced downward flux of degradable organic matter from phytoplankton blooms fuels oxygen demand and the regeneration of $\mathrm{P}$ in bottom waters creating a positive feedback between anthropogenic nutrient enrichment, $\mathrm{N}$-fixation by cyanobacteria, and oxygen depletion (Figure 6). In addition to being a significant source of new $\mathrm{N}$ to the BS, Nodularia spumigena has the capacity to produce hepatotoxins that can cause liver damage in humans (Sipiä et al., 2002; van Apeldoorn et al., 2007; Mazur-Marzec and Pliñski, 2009). Thus, their harmful effects include both oxygen depletion and the production of toxic metabolites.

\section{Northern Adriatic Sea (NA)}

With an area of $18,900 \mathrm{~km}^{2}$, the continental shelf of the NA is a relatively flat platform that extends from the coastline to a water depth of $100 \mathrm{~m}$ (mean depth $=33.5 \mathrm{~m}$ ). A progressive increase in eutrophication began in the early 20th C, continued to $\sim 1978$, and subsequently began to decrease (Sangiorgi and Donders, 2004). The Po River accounts for most inputs of freshwater and nutrients with minor contributions from the Soča (Isonzo) and Adige Rivers (Pettine et al., 1998; Cozzi and Giani, 2011). The annual cycle of Po River discharge is characterized by seasonal peaks during April-June and September-December

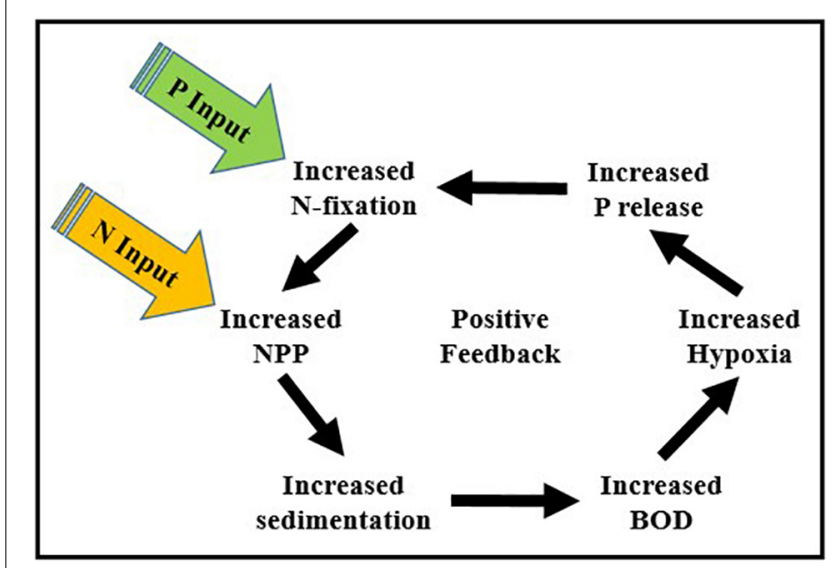

FIGURE 6 | The positive feedback between anthropogenic inputs of $\mathrm{N}$ and $\mathrm{P}$, $\mathrm{N}$-fixation by cyanobacteria, increases in NPP, and oxygen depletion driven by the release of $P$ from benthic sediments under low oxygen conditions (NPP, net phytoplankton production; BOD, biological oxygen demand).

with minimum flows during August (Marini et al., 2008). During May-September when the water column is well stratified, the plume of the Po River spreads across much of the northern basin 
and maintains a wide cross-shelf profile as it flows southward. The volume transport of the Po during 1970-2002 fluctuated around $47 \mathrm{~km}^{3} \mathrm{yr}^{-1}$ with a minimum discharge of $\sim 30 \mathrm{~km}^{3}$ $\mathrm{yr}^{-1}$ and a maximum discharge of $\sim 80 \mathrm{~km}^{3} \mathrm{yr}^{-1}$ (Giani et al., 2012; Montanari, 2012; Ninfo et al., 2018). A marked decrease in the flow of the Po River occurred during 2003-2007 due to a prolonged drought (Cozzi and Giani, 2011; Djakovac et al., 2015).

Diffuse sources account for $80 \%$ of $\mathrm{N}$ input and $93 \%$ of $\mathrm{P}$ input (European Topic Center [ETC], 2016). Prior to the drought years, river borne transports of $\mathrm{N}$ and $\mathrm{P}$ to the NA

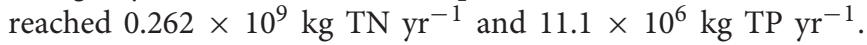
These inputs decreased by $50-70 \%$ during the drought years, but returned to their pre-drought levels in subsequent years (Cozzi and Giani, 2011; Giani et al., 2012). N-fixation does not contribute significantly to the $\mathrm{N}$ budget, and denitrification accounts for $\sim 42 \%$ of $\mathrm{N}$ losses $\left(\sim 0.10 \times 10^{9} \mathrm{~kg} \mathrm{yr}^{-1}\right)$ or $\sim 40 \%$ of the riverine $\mathrm{N}$ inputs (Degobbis and Gilmartin, 1990).

Phytoplankton NPP and biomass are highest in the Po River plume (Figure 7; Degobbis et al., 2000; Fiori et al., 2016), and annual cycles mirror the annual cycle of river flow while annual cycles in oligotrophic waters beyond the plume have a relatively small amplitude with small peaks during OctoberNovember (Revelante and Gilmartin, 1992; Harding et al., 1999; Mozetič et al., 2010). Chl concentrations ranged from 4 to 35 $\mu \mathrm{g}$ liter $^{-1}$ in the plume to $1-4 \mu \mathrm{g} \operatorname{liter}^{-1}$ in offshore waters of the central NA and were $<1 \mu \mathrm{g} \operatorname{liter}^{-1}$ in coastal waters of the eastern NA (Polimene et al., 2006; Solidoro et al., 2009; Mozetič et al., 2010). Phytoplankton blooms in the coastal plume of the Po are dominated by large diatoms $(>20 \mu \mathrm{m})$ interspersed by diverse assemblages of nanoflagellates $(<20 \mu \mathrm{m})$ with small dinoflagellate blooms during spring-summer. Small phytoplankton dominate in more oligotrphic waters outside the plume where microbial food webs predominate (Polimene et al., 2006). Coccolithophores are minor but regular inhabitants of these phytoplankton communities (Bernardi-Aubry et al., 2004; Totti et al., 2005, 2019).

The 2003-2007 drought resulted in marked decreases in phytoplankton NPP and Chl. Concentrations of nutrients and Chl remained low after higher river discharges returned during 2008-2016, possibly due to improved control of nutrient loads to the watershed (Totti et al., 2019). However, greater intrusions of high salinity, oligotrophic waters from the eastern Mediterranean Sea also played a role (Solidoro et al., 2009). More recent observations suggest that phytoplankton biomass may be increasing in the southern reaches of the western NA where both DIN and DIP concentrations have been increasing (Totti et al., 2019).

Sedimentation of phytoplankton biomass to the benthos, estimated to be $25-30 \%$ of phytoplankton NPP, fuels high biological oxygen demand in bottom waters from late spring to early autumn (Staresinié et al., 1982; Alvisi and Cozzi, 2016). During this period, dissolved oxygen levels in bottom water are low and episodes of bottom water hypoxia occur frequently. The timing, duration and spatial extent of these episodes varies from year-to-year. During 1972-2012, the frequency of hypoxic events was high each year from 1988 to 1991, especially in the western NA (Djakovac et al., 2015). While hypoxia is related to phytoplankton blooms induced by riverine inputs of nutrients

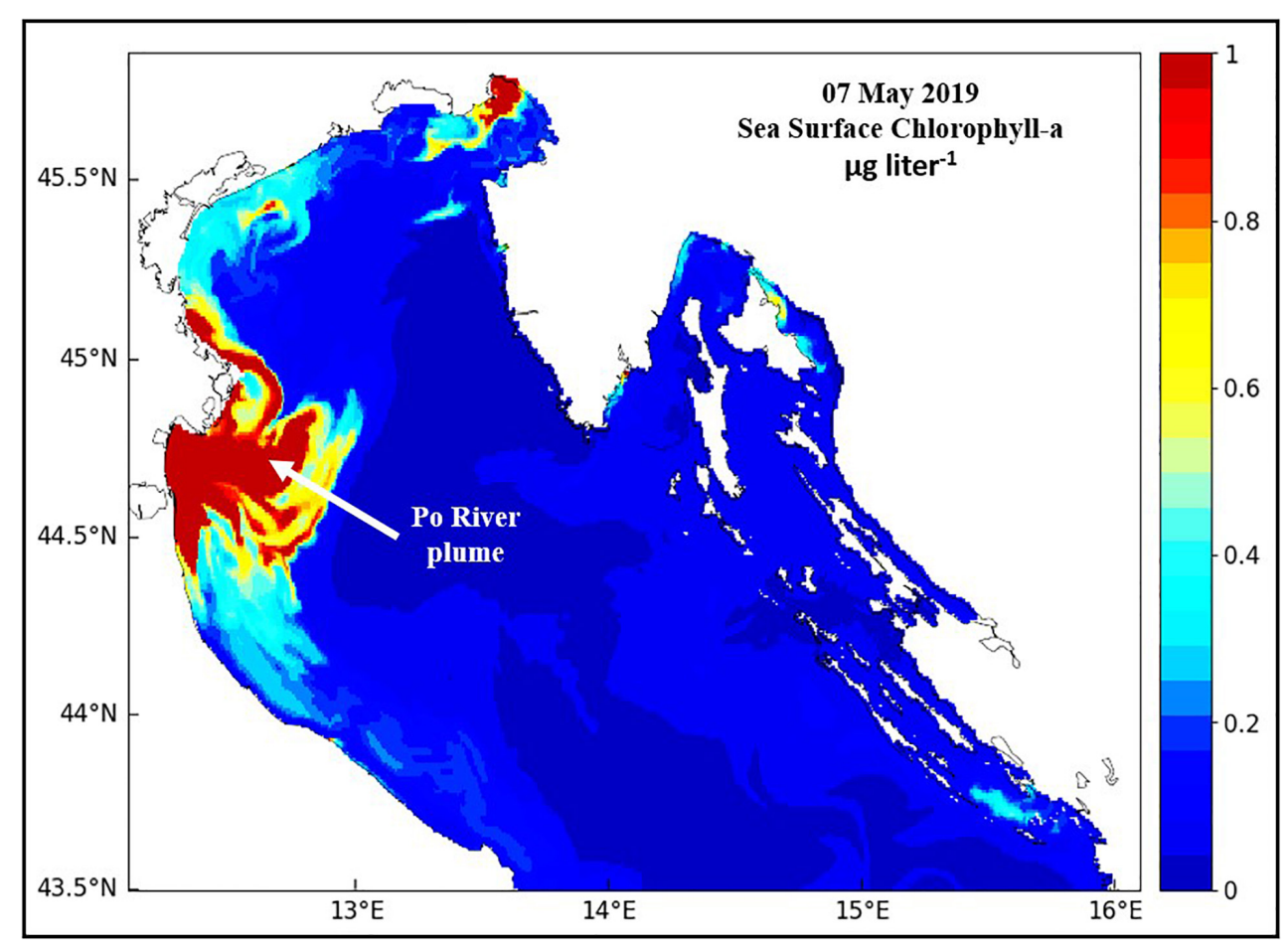

FIGURE 7| The high phytoplankton biomass (red - high, blue - low) footprint of the coastal plume of the Po River in the northern Adriatic Sea. 
during spring and autumn, summer hypoxia occurs during periods of low runoff suggesting that strong vertical stratification and weak circulation promoted hypoxic events during summer (Alvisi and Cozzi, 2016). Hypoxic zones range in spatial extent from several $\mathrm{km}^{2}$ to $4,000 \mathrm{~km}^{2}$ and ultimately affect most of the NA (Riedel et al., 2008). Thus, repeated episodes of hypoxia caused mass mortalities of benthic macrofauna during the 1970s and 1980s, the largest of which were caused by anoxic episodes during the summers of 1974, 1977, 1983, 1988, and 1989 (Fedra et al., 1976; Stachowitsch, 1984; Ott, 1992).

In addition to phytoplankton sedimentation, the formation and deposition of macro-aggregates ("mucilage" or mare sporco) of organic matter rich in bacteria also fuels high biological oxygen demand, anoxia and mass mortalities during MaySeptember (Degobbis, 1989). Mucilage episodes are unique to the NA in terms of the size of macro aggregates (up to $3 \mathrm{~m}$ across) and their abundance and spatial coverage (hundreds of $\mathrm{km}^{2}$ in both coastal and offshore waters). Episodes have occurred sporadically since the seventeenth century (Fonda Umani et al., 1989; Sellner and Fonda Umani, 1999; Giani et al., 2005), but increased in frequency during 1980-2004 (Danovaro et al., 2009). Major episodes (2-6 weeks in duration) occurred annually during 1988-1991, 1996-1998, and 20002004. Following a prolonged episode from December, 2006 through April, 2007, episodes of relatively short duration were recorded in 2014 (August) and 2018 (July-August). Although these episodes tend to occur following increases in river runoff, and mucilage production occurs during diatom blooms (McKinney, 2007), anthropogenic nutrient enrichment may not be directly responsible (Degobbis et al., 2005).

Since the 1990s, many toxic or potentially toxic phytoplankton species have inhabited the NA including dinoflagellates (e.g., Dinophysis spp., Alexandrium minutum, Noctiluca scintillans, Protoceratium reticulatum, Gonyaulax spinifera, and Lingulodinium polyedrum), diatoms (Psedo-nitzschia spp.), and a raphidophyte (Fibrocapsa japonica) (Sellner and Fonda Umani, 1999; Fonda Umani et al., 2004; Mikaelyan et al., 2014; Corriero et al., 2016). The first occurrence of human intoxication due to the consumption of bivalves contaminated with diarrhetic shellfish poisoning (DSP) toxins was documented in 1989 (Pistocchi et al., 2012). The first detection of bivalves contaminated by toxins produced by a bloom of Alexandrium minutum that cause paralytic shellfish poisoning (PSP) was in 1994 (Honsell et al., 1996). Domoic acid, produced by the diatom Pseudo-nitzschia spp., is a potentially lethal phycotoxin that causes amnesic shellfish poisoning (ASP), and was first detected in bivalve-tissue in 2006 (Ujević et al., 2010). Bivalves farmed in coastal waters of Emilia Romagna and in Slovenian mariculture areas have also been contaminated frequently by Dinophysis spp. toxins (okadaic acids and dinophysitoxin) that cause DSP (Francé and Mozetič, 2006; Pistocchi et al., 2012). Alerts due to the presence of biotoxins in the Gulf of Trieste increased steadily from $10 \mathrm{yr}^{-1}$ in 2005 to $60 \mathrm{yr}^{-1}$ in 2010 and then declined to 1 $\mathrm{yr}^{-1}$ in 2013 and 2014 (Lipizer et al., 2017).

Given the pattern of interannual variations in river flow and associated nutrient inputs described above, it is unlikely that the frequency of toxic phytoplankton episodes is related directly to the magnitude of nutrient enrichment per se. However, relative inputs of $\mathrm{N}$ and $\mathrm{P}$ can affect the abundance of potentially toxic phytoplankton as well as toxin production (Glibert et al., 2014; Glibert and Burford, 2017). Many marine dinoflagellate species are more abundant and toxic when $\mathrm{N}$ is in stoichiometric excess over $\mathrm{P}(\mathrm{N}: \mathrm{P}>16)$, as is the case in the Northern Adriatic where $\mathrm{N}: \mathrm{P}$ ratios have increased from a mean of 64 during the 1960s to $>100$ in more recent years.

\section{Main Stem of Chesapeake Bay (CB)}

$\mathrm{CB}$ is a long, narrow system (315 km long and 5.6-56 km wide) with a surface area of $11,600 \mathrm{~km}^{2}$ (Xiong and Berger, 2010) and three salinity zones (Harding et al., 2019): oligohaline $<5-18$, mesohaline 5-18, and euryhaline $>18$. A relatively deep $(10-50$ $\mathrm{m})$ central channel runs the length of the mesohaline zone. The Susquehanna River discharges directly into the oligohaline zone and, with a mean flow of $36 \mathrm{~km}^{3} \mathrm{yr}^{-1}$ (range 20-60 $\mathrm{km}^{3} \mathrm{yr}^{-1}$ ), accounts for $60-90 \%$ of the freshwater input to CB (Schubel and Pritchard, 1986; Zhang et al., 2013). Except for the effects of tropical storms, the volume transport of the Susquehanna has a well-defined annual cycle with maximum flow during late winterearly spring and low flow during summer. Large interannual variations occur (20-60 $\left.\mathrm{km}^{3} \mathrm{yr}^{-1}\right)$ in both the magnitude and timing of seasonal maximum and minimum flows.

The Susquehanna drives an estuarine circulation characterized by seaward transport of low salinity surface water and landward (counter) transport of higher salinity bottom water, a circulation pattern that increases the residence time of nutrients in the Bay (Pritchard, 1967; Shen and Wang, 2007; Du and Shen, 2016). Peak flow during winter-spring sets up buoyancy-induced vertical stratification that persists into early fall, with high flow years having a stronger halocline separating upper and bottom layers (Boynton and Kemp, 2000; Kemp et al., 2005).

Dissolved nitrate accounts for most input of new $\mathrm{N}$ while most $\mathrm{P}$ input is associated with the input of suspended sediments (Boynton et al., 1995; Zhang et al., 2013). It is estimated that $\mathrm{N}$ and $\mathrm{P}$ loads increased by factors of $7(\mathrm{~N})$ and $13(\mathrm{P})$ between the beginning of the Anthropocene ${ }^{21}$ and 1985-86 when loads reached $0.081 \times 10^{9} \mathrm{~kg} \mathrm{~N} \mathrm{yr}^{-1}$ and $3.75 \times 10^{6} \mathrm{~kg} \mathrm{P} \mathrm{yr}^{-1}$ (Boynton et al., 1995; Boynton and Kemp, 2000). N loading during 1945-2011 increased from 1945 to around 1990, followed by a steady decline (Zhang et al., 2013). Mean inputs during 1978-2011 were $0.071 \times 10^{9} \mathrm{~kg} \mathrm{~N} \mathrm{yr}^{-1}$ and $3.3 \times 10^{6} \mathrm{~kg} \mathrm{P}$ $\mathrm{yr}^{-1}$ (Hirsch, 2012). Relative to riverine inputs, inputs from direct precipitation to the Bay are small (7\% of TN and 15\% of TP). N-fixation is assumed to be negligible (Marino et al., 2002), and benthic denitrification that is estimated to remove $0.034 \times 10^{9} \mathrm{~kg} \mathrm{~N} \mathrm{yr}^{-1}$ or $\sim 40 \%$ of annual riverine $\mathrm{N}$ inputs (Feng et al., 2015).

The annual cycle of phytoplankton biomass in the Bay features a large spring bloom which is most pronounced in the mesohaline Bay where integrated water column Chl can exceed 1,000 mg $\mathrm{m}^{-2}$ (Malone et al., 1988, 1996) due to phytoplankton growth,

\footnotetext{
${ }^{21}$ A geological epoch, supplementing the Holocene, when anthropogenic activities became a dominant driver of environmental change as indicated by the rapid rise in atmospheric carbon dioxide and methane that began in the latter part of the eighteenth century (Crutzen, 2002; Waters et al., 2016).
} 
the concentrating effect of the two-layered estuarine circulation on phytoplankton biomass, and low grazing pressure (Malone et al., 1988, 1996; White and Roman, 1992). The spring bloom is dominated by large diatoms that deplete nitrate and silicate in surface waters and have high sinking rates (Conley and Malone, 1992) resulting in the deposition of phytoplankton biomass to bottom waters and benthic sediments (Malone et al., 1988; Harding et al., 2002). Remineralization of this organic matter during summer results in oxygen depletion and a large efflux of dissolved phosphate and ammonium into bottom waters which gradually mix into surface waters (Boynton et al., 1995; Boynton and Kemp, 2000) where they fuel local, episodic summer blooms of small diatoms, chlorophytes, cyanobacteria, dinoflagellates, and picophytoplankton (Malone, 1991; Adolf et al., 2006; Marshall et al., 2009). For the most part, summer blooms are confined to the euphotic zone and there is relatively little sedimentation to the benthos. Consequently, the positive feedback that characterizes the Baltic (Figure 5) is not well developed in CB.

Annual cycles (1982-2004) of Chl and phytoplankton NPP for the oligohaline, mesohaline, and polyhaline zones of the Bay have been characterized as follows (Harding et al., 2002, 2020):

- Oligohaline - The annual cycles of phytoplankton biomass and NPP are seasonally in phase with maxima during JulyAugust when $\mathrm{Chl}$ in the euphotic zone reaches $\sim 40 \mathrm{mg}$ $\mathrm{m}^{-2}$ and NPP reaches $\sim 1200 \mathrm{mg} \mathrm{C} \mathrm{m}^{-2} \mathrm{~d}^{-1}$.

- Mesohaline - The annual cycles are out of phase with biomass typically peaking during April-May Chl (80$100 \mathrm{mg} \mathrm{Chl} \mathrm{m}^{-2}$ ) and NPP peaking during July ( $>2000 \mathrm{mg}$ $\left.\mathrm{C} \mathrm{m}^{-2} \mathrm{~d}^{-1}\right)$; a second, lower peak in Chl (60-80 $\left.\mathrm{mg} \mathrm{m}^{-2}\right)$ often occurs in November.

- Polyhaline - The annual cycles are out of phase with biomass typically peaking in May $\left(\sim 60 \mathrm{mg} \mathrm{m}^{-2}\right)$ and NPP in September $\left(\sim 1700 \mathrm{mg} \mathrm{m}^{-2} \mathrm{~d}^{-1}\right)$.

Seasonal to interannual variations in riverine $\mathrm{N}$ input regulate the distribution of phytoplankton biomass in both time and space (Harding et al., 2020), consistent with the conclusion that $\mathrm{P}$ limitation occurs predominantly in the oligohaline reach of the Bay, while N limits phytoplankton biomass and NPP on the scale of the CB ecosystem (Malone et al., 1996). Anthropogenic nutrient loading led to a 5- to 10-fold increase of surface $\mathrm{Chl}$ in the polyhaline salinity zone and a 1.5 - to 2 -fold increase in the oligohaline and mesohaline zones from the 1950s to the 1990s (Harding et al., 2002, 2020). However, while euphotic zone Chl continued to increase in the oligohaline and mesohaline zones during 1985-2015, no trend was observed in the polyhaline zone (Harding et al., 2020).

Dissolved oxygen in bottom waters declines rapidly during April-May leading to hypoxic bottom water during JulySeptember throughout most of $\mathrm{CB}$, with hypoxia and anoxia developing in the deep channel of the mesohaline (Figure 8; Officer et al., 1984; Li et al., 2015). This cycle is driven by the spring bloom and bacterial decomposition of phytoplankton biomass deposited during the course of the bloom (Malone, 1991; Smith and Kemp, 1995). Summer bottom water hypoxia has been documented in the mesohaline salinity zone throughout the twentieth century and, while interannual variability is substantial, the volume of hypoxia has increased significantly since WWII as anthropogenic $\mathrm{N}$ loading to the Bay increased (Brush, 2009; Murphy et al., 2011; Li et al., 2016; Testa et al., 2017). Under current conditions, it is estimated that the missing biomass of benthic animals due to hypoxia is equivalent to $\sim 10,000$ metric tons of carbon annually which represents $\sim 5 \%$ of the Bay's secondary production (Diaz and Rosenberg, 2008).

In addition, long-term increases in Chl, combined with increases in sediment loading to the Bay, have been linked to bay-wide declines in the spatial extent of seagrass beds during the 1960s and 70s due to reduced light penetration (Orth and Moore, 1983; Kemp et al., 2005). As a result, it is estimated that the spatial extent of seagrass decreased by $46 \%$ between the 1930 s and the 1990s (Kemp et al., 2005). These decreases persisted through the 1990s (Orth et al., 2010; Harding et al., 2019) but show signs of increasing since $\sim 2006$ during a sustained low-flow period (Testa et al., 2019).

Harmful algal blooms in CB are not a new phenomenon, but they may be increasing in frequency and diversity (Glibert et al., 2001). As in most coastal ecosystems, dinoflagellates account for most toxic or potentially toxic phytoplankton. Prorocentrum cordatum, Karlodinium veneficum, and Margalefidinium polykrikoides have occurred with increasing frequency in recent years (Tango et al., 2005; Li et al., 2015; Reece, 2015; Lin et al., 2018). Beginning in 2007, and blooms of Alexandrium monilatum also began occurring in the lower bay in most summers following blooms of M. polykrikoides (Reece, 2015). P. cordatum, M. aeruginosa and the diatom Pseudo-nitzschia spp. are common throughout the bay; K. veneficum is limited to the oligohaline and mesohaline zones; and Dinophysis acuminata and $M$. polykrikoides are limited to the mesohaline and polyhaline zones. All species were found in all seasons, but are generally most abundant during summer and fall ${ }^{22}$.

\section{Coastal Upwelling: Santa Barbara Channel (SBC)}

Coastal upwelling centers represent an extreme case of natural new nutrient inputs and are expected to exhibit equally

${ }^{22}$ https://www.chesapeakebay.net/what/downloads/cbp_water_quality_database_ 1984_present (Accessed April 21, 2020).

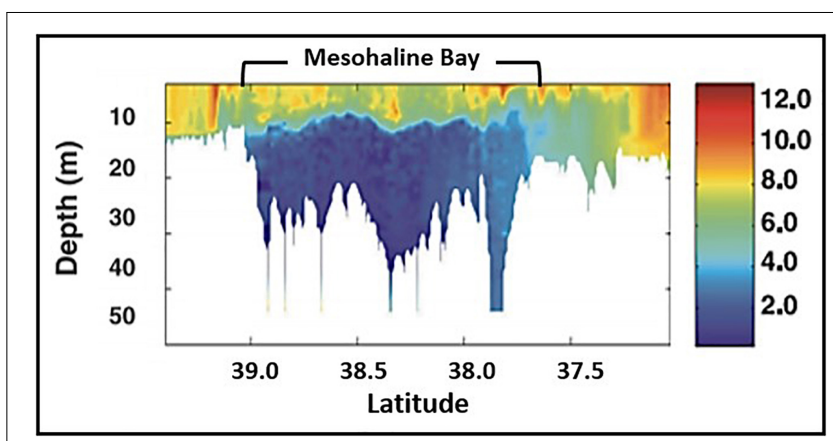

FIGURE 8 | Distribution of dissolved oxygen $\left(\mathrm{mg} \mathrm{liter}^{-1}\right)$ along the main axis of Chesapeake Bay in summer, 2000 (modified from Costantini et al., 2008). 
extreme blooms of both benign and toxic phytoplankton (Kudela et al., 2010). Unlike most coastal ecosystems impacted by eutrophication, the physical, chemical, and ecological characteristics of eastern boundary currents, such as the California current system, are dominated by wind-driven coastal upwelling which enriches these waters with nutrients far in excess of riverine inputs of anthropogenic nutrients (Anderson et al., 2008).

The Santa Barbara Channel (SBC) in the Southern California Bight is an elongated ecosystem $\left(4,000 \mathrm{~km}^{2}\right)$ bounded to the north by the California coast, to the south by the Channel Islands $50 \mathrm{~km}$ offshore, and by narrow, relatively shallow sills to the west $(475 \mathrm{~m})$ and east $(200 \mathrm{~m})$ (Bograd et al., 2002). Between these sills lies the Santa Barbara Basin which is periodically flushed with cool, dense, oxygenated water that flows over the western sill and sinks into the basin. Waters below the deepest sill are dysaerobic (dissolved oxygen $<0.1 \mathrm{ml} \mathrm{liter}^{-1}$ ) between flushing events (Bernhard and Reimers, 1991). Flushing event frequency of deep water is driven by interannual climate (ENSO) variability, which switches the basin between a stagnant water column and a ventilated one, a process that amplifies variability in the magnitude of oxygen depletion (Bograd et al., 2002; Wang et al., 2017).

Upwelling is by far the largest source of nutrients to the SBC ecosystem as a whole, especially during the late spring and early summer (Warrick et al., 2005; Howard et al., 2017). N input via upwelling is estimated to be $\sim 0.21 \times 10^{9} \mathrm{~kg} \mathrm{yr}^{-1}$, a rate that is 2-3 orders-of-magnitude greater than the riverine inputs during wet, El Nino years (Warrick et al., 2005). The largest river flowing into the Channel is the Santa Clara River with an annual mean flow of $0.16 \mathrm{~km}^{3} \mathrm{yr}^{-1}$. Although total riverine $\mathrm{N}$ input is much less than that supplied by upwelling, the timing these inputs are seasonally out of phase with river runoff peaking during winter storms and upwelling during spring-summer (Warrick et al., 2005; Anderson et al., 2008). In addition, upwelling inputs occur at the western end of the basin while riverine inputs occur along the eastern boundary.

Although the distribution of phytoplankton biomass in the $\mathrm{SBC}$ is complex, the long-term climatology of surface Chl concentration (derived from satellite ocean color images) reveals two consistent features: (1) maximum biomass north of the Channel Islands and over the Santa Barbara Basin and (2) a second maximum along the coast in the eastern SBC where the continental shelf widens (Warrick et al., 2005; Brzezinski and Washburn, 2011). It is estimated that new production ${ }^{23}$ from river runoff accounts for $0.03-4 \%$ of total new production (river + upwelling) within the SBC. Since upwelling is generally lower during El Niño, river contributions are most significant during these years ( $\sim 4 \%$ of new production in 1998) (Warrick et al., 2005). However, while high phytoplankton biomass over the basin and north is fueled primarily by upwelling, the near shore maximum to the east is fueled by a combination of mechanisms including upwelling, diurnal internal waves, and

\footnotetext{
${ }^{23}$ Inputs of new nutrients (e.g., nitrate via upwelling) from outside an ecosystem supports "new" phytoplankton production in contrast to "regenerated" production supported by nutrients recycled (e.g., ammonium) within the ecosystem (Dugdale and Goering, 1967).
}

river runoff (McPhee-Shaw et al., 2007). Upwelling dominates increases of inner-shelf DIN during March-May and accounts for more than half of annual advective inputs. Internal waves are an important source during summer, and riverine inputs are significant during winter.

The frequency of toxic phytoplankton blooms increased during the first decade of this century (Anderson et al., 2009). Episodic blooms of potentially toxic species (the diatom Pseudonitzschia spp. and the dinoflagellate Lingulodinium polyedrum) occur along the coastline of the Southern California Bight including the SBC (Bialonski et al., 2016). Blooms of Pseudonitzschia and Lingulodinium tend to occur during spring-summer when upwelling events are most frequent (Schnetzer et al., 2013). However, this does not preclude the possibility that the growth of these algae, their toxicity, and the frequency or duration of toxic events may be exacerbated by anthropogenic nutrient inputs (Anderson et al., 2008). Blooms can occur during fall or winter, presumably fueled by riverine inputs of nutrients (Kudela et al., 2010). Other toxin-producing phytoplankton that occur here include dinoflagellate species from the genera Akashiwo, Alexandrium, Cochlodinium, and Dinophysis.

Bottom water oxygen in the basin has been decreasing since about 1850 due to upper ocean warming (decreases in solubility and vertical mixing) (Wang et al., 2017), and the frequency and duration of hypoxia in California Current waters has been increasing as the Eastern Pacific oxygen minimum zone expands (Stramma et al., 2010; Wang et al., 2017). The spatial extent of oxygen depleted deep water is estimated to be on the order of $800 \mathrm{~km}^{2}$. Low-oxygen water $($ mean $=0.5 \mathrm{ml}$ liter $^{-1}$ during 2008-2011) from the oxygen minimum enters the basin over the western sill and is further depleted of oxygen by the decomposition of organic matter from productive surface water fueled primarily by upwelled nutrients and exacerbated by riverine inputs of anthropogenic nutrients (Ohkushi et al., 2013). An indication of the significance of the latter is the observation that dissolved oxygen in nearshore bottom water (within $10 \mathrm{~km}$ of the shoreline) has declined by up to four times faster than reported for more offshore waters over the last 15 years (Booth et al., 2014). The trend has been briefly interrupted when dense oxygenated water flows into the basin during transitions from El Niño to La Niña conditions (Wang et al., 2017). Thus, anthropogenic nutrients can have an impact on local spatial scales within the larger upwelling ecosystem (Howard et al., 2017).

\section{FILTERS: SUSCEPTIBILITY TO EUTROPHICATION}

The seasonal development of bottom water hypoxia is driven primarily by river borne nutrient inputs in the NGM, ECS, NA, and $\mathrm{CB}$; by the cumulative inputs of both riverine inputs and $\mathrm{N}$-fixation in the GBR and BS; and by upwelling in the SBC. In addition to the spatial extent of bottom water hypoxia (Table 1), decadal scale increases in summer toxic phytoplankton events have been observed in the NGM, ECS, BS, NA, CB, and SBC. With the exception of the SBC where DIN:DIP is $<10$, each of these ecosystems is characterized by DIN:DIP molar ratios that are 
significantly above the Redfield Ratio of 16 which promotes the growth of toxic dinoflagellates (Glibert and Burford, 2017). Only the GBR, where DIN:DIP ratios are $<16$, has not experienced significant decadal increases in toxic blooms. In addition, while biologically engineered habitats have been lost in all ecosystems except the SBC, four systems are particularly significant in this regard: (i) losses of tidal marshes (Mitsch et al., 2005) and oyster reefs in the NGM (Peyronnin and Condrey, 2017); (ii) degradation of coral reefs in the GBR system (Bell, 1992; Bell et al., 2014); (iii) losses of seagrass meadows and brown algae in the BS, and (iv) losses of oyster reefs (Newell, 1988; Theuerkauf et al., 2019a) ${ }^{24}$ and seagrass meadows (Orth and Moore, 1983) in $\mathrm{CB}$. Given these expressions of eutrophication, CB ranks highest in terms of cumulative impacts followed in rank order by the BS, NA, NGM, SBC, ECS, and the GBR (Table 1).

To what extent are these expressions of eutrophication reflections of the magnitude of N loading and levels of NPP? Despite major contrasts in the magnitude of $\mathrm{N}$ loading, NPP was $<300 \mathrm{~g} \mathrm{C} \mathrm{m}^{-2} \mathrm{yr}^{-1}$ in all ecosystems except $\mathrm{CB}$ and the SBC (Table 1). While the $\mathrm{N}$ load to the BS is nearly an order of magnitude higher than that to $\mathrm{CB}$, mean NPP of the BS is nearly three times lower than that of $\mathrm{CB}$. However, the BS is ranked lower than $\mathrm{CB}$ in terms of the severity of eutrophication. Likewise, while nutrient loading to the ECS is more than an order of magnitude greater than to $\mathrm{CB}$, NPP of CB is twice that of the ECS and the ECS is ranked 6th in terms of the severity of eutrophication while CB is ranked 1st (Table 1). These relationships underscore the importance of viewing impacts in the context of their spatial extent relative that of the ecosystem as specified by boundary conditions.

In terms of susceptibility, it has been known for some time that coastal ecosystems vary in their sensitivity to anthropogenic nutrient enrichment based on key characteristic of each ecosystem (Cloern, 1982, 2001; Officer et al., 1982; National Research Council [NRC], 2000; Smith et al., 2003; Dalsgaard et al., 2005; Theuerkauf et al., 2019a). Among the more important of these are the dilution potential of nutrient inputs within the ecosystem, residence times of nutrients in the ecosystem, export of $\mathrm{N}$ via denitrification and anammox ${ }^{25}$ from the ecosystem, biofiltration ${ }^{26}$ within the ecosystem, and synergies with other pressures. Based on its long residence time (Stigebrandt, 2001) and low dilution potential, the BS is highly susceptible to eutrophication while the susceptibility of the GBR is low due to its short residence time and high dilution potential

\footnotetext{
${ }^{24}$ The standing stock of filter feeding oysters is estimated to have decreased to $<2 \%$ of that present prior to the twentieth century due to over fishing and disease, a decline that has exacerbated the impacts of increasing anthropogenic nutrient enrichment (Newell, 1988).

${ }^{25}$ Denitrification is generally the dominant pathway for $\mathrm{N}$ removal in coastal ecosystems (Dalsgaard et al., 2005). Denitrification removes nitrogen from an ecosystem by converting fixed nitrogen to dinitrogen gas, which can then be lost to the atmosphere. Coastal marine sediment plays a critical role in $\mathrm{N}$ losses via denitrification and anaerobic ammonium oxidation (anammox) and release of nitrous oxide.

${ }^{26}$ Biofiltration by oyster reefs has declined globally by $85 \%$ making coastal ecosystems, such as Chesapeake Bay and the northern Gulf of Mexico, more susceptible to eutrophication due to the associated decline in biofiltration (Theuerkauf et al., 2019a,b).
}

(Wang et al., 2007; Table 1). The importance of $\mathrm{N}$ export via denitrification and anammox is particularly apparent in the ECS while zooplankton grazing appears to be an important loss term in the NGM (Dagg, 1995) and the BS (Lignell et al., 1993). At the same time, the loss of oyster reefs in CB and the NGM has reduced biofiltration and increased the susceptibility of these ecosystems to eutrophication.

Despite major differences in $\mathrm{N}$ loading and in the relationship between $\mathrm{N}$ load and impacts (Table 1), all of these systems except $\mathrm{CB}$ and the SBC would be classified as mesotrophic based on annual phytoplankton NPP (Nixon, 1995; Table 1). Perhaps criteria based on the impacts of changes in phytoplankton biomass, such as those described above, would be more useful. As emphasized by Newton et al. (2003), these relationships highlight a significant problem with defining trophic status in terms of specific, quantitative ranges of NPP, a problem that is exacerbated by synergies with other pressures.

\section{THE PERFECT STORM: SYNERGIES AMONG PRESSURES}

The impacts of continued increases in $\mathrm{N}$ loading are likely to be exacerbated by synergies with other pressures, especially over fishing, coastal development, and climate-driven warming, acidification and increases in wet precipitation (Newton et al., 2012; Paerl et al., 2019). Thus, it is likely that the severity and extent of coastal eutrophication will continue to increase in the absence of aggressive actions to reduce diffuse inputs of anthropogenic $\mathrm{N}$ and $\mathrm{P}$ to coastal watersheds and airsheds (Boyer and Howarth, 2008; Swaney et al., 2012; Townhill et al., 2018). Examples of synergies are given below to illustrate the problem.

- The spatial extent of hypoxic bottom water is forecast to continue increasing, primarily due to the combined effects of ongoing increases in anthropogenic nutrient inputs to coastal watersheds, increases in fishing pressure, ocean warming, and increases in wet precipitation (Huntington, 2006; Eriksson et al., 2009; Rabalais et al., 2009; Altieri and Gedan, 2015; Cloern et al., 2016; Sinha et al., 2017; Breitburg et al., 2018); and it is likely that the rate of biodiversity loss in coastal ecosystems will increase as a consequence (Diaz and Rosenberg, 1995; Vaquer-Sunyer and Duarte, 2008).

- Regional declines of large predatory fish in the Baltic Sea have been shown to promote eutrophication by decreasing grazer control of algal biomass by minnows and other small grazers (Eriksson et al., 2009; Bergström et al., 2019).

- The development of hypoxic bottom water amplifies acidification caused by the ocean's assimilation of $\mathrm{CO}_{2}$ resulting in decreases in $\mathrm{pH}$ to levels that have an adverse impact on calcifying organisms including shellfish, planktonic pteropods and corals (IPCC, 2014; Wallace et al., 2014; Anderson et al., 2015; Ekstrom et al., 2015; Laurent et al., 2018).

- Hard coral cover on the GBR decreased by $>70 \%$ during the twentieth century, apparently due to a combination of nutrient-driven increases in $\mathrm{Chl}$ concentration and 
macroalgal cover, storm damage, coral bleaching, widespread growth of the crown of thorns starfish, and coral skeletal diseases (Bell et al., 2014). Chronic exposure of coral reefs to excess nutrient enrichment enhances coral bleaching during warming events and increases the severity of disease in stony corals (VegaThurber et al., 2014). In addition, overfishing and nutrient pollution reduce the resilience of coral reefs by increasing coral-algal competition and reducing coral recruitment, growth and survivorship (Zaneveld et al., 2016).

- The frequency of toxic algal events appears to be on the rise to the detriment of marine animals and people (Heisler et al., 2008; Glibert and Burford, 2017), a trend that appears to be driven by synergies among increases in anthropogenic nutrient enrichment, N:P ratios, sea surface temperature, vertical stratification (Glibert et al., 2014, 2018; Gobler et al., 2017; Wurtsbaugh et al., 2019), and overfishing (Vasas et al., 2007).

\section{IMPACTS OF CULTURAL EUTROPHICATION ON ECOSYSTEM SERVICES}

Cultural eutrophication has major consequences for the biodiversity of coastal ecosystems and the services they provide to society, including fish production, protection from coastal erosion and flooding, water filtration, and nutrient cycling. Examples of impacts of eutrophication on services include the following:

(i) The development of oxygen deficient bottom waters leads to declines in the abundance of macrobenthic animals and to increases in energy flow through microbial food webs relative to energy flow through metazoan food webs that support mobile consumers (e.g., fisheries), a shift that may reduce the carrying capacity for fisheries in some ecosystems (Diaz and Rosenberg, 2008; Condon et al., 2011; Figure 9).

(ii) It is estimated that eutrophication in the Baltic Sea has resulted in a decline in ecosystem services at a cost of $\sim \$ 4,400 \mathrm{yr}^{-1}$ (Elofsson, 2010; HELCOM, 2018a).

(iii) Warm water coral reefs provide in excess of $\$ 375$ billion in services annually that benefit $>500$ million people in at least 90 countries worldwide (Hoegh-Guldberg et al., 2017).

(iv) Mangrove forests, salt marshes, seagrass beds, and coral reefs provide nursery grounds for marine animals and provide protection against coastal flooding and erosion (Koch et al., 2009).

(v) Toxic phytoplankton events have had negative impacts to fisheries, coastal ecosystems, public health, and coastal economies (Anderson et al., 2015). The economic cost of these events to the EU has been estimated to be on the order of $\$ 1$ billion per year (Hoagland and Scatasta, 2006).

It is important to emphasize that these impacts should be viewed in the context of their spatial extent relative to the size of the ecosystem as a whole. While $\mathrm{N}$ enrichment usually causes increases in biological production, and hypoxia reduces biomass and the availability of suitable habitat, the relationship between $\mathrm{N}$ loading and fish landings is complex (e.g., Chesney et al., 2000; de Mutser et al., 2016). A comparison of 30 coastal ecosystems worldwide shows that when the spatial extent of bottom water hypoxia is $<20 \%$ of the ecosystem's area, fish landings per unit $\mathrm{N}$ loading (kg wet weight per $\mathrm{kg} \mathrm{N}$ ) range between 0.1 and 2.1, but when spatial extent was $>20 \%$, landings per $\mathrm{N}$ loading were consistently $<0.5$ (Breitburg et al., 2009).

\section{MANAGING DIFFUSE INPUTS}

Although $\mathrm{N}$ supply typically limits the magnitude of seasonal phytoplankton blooms in coastal ecosystems, both $\mathrm{P}$ and $\mathrm{N}$ inputs

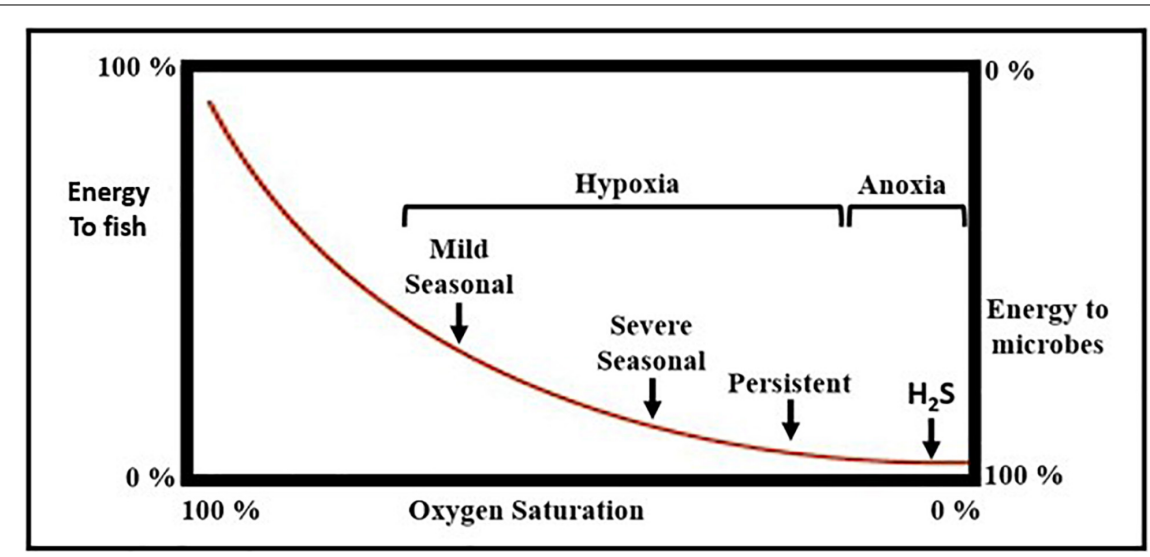

FIGURE 9 | Conceptual diagram of how hypoxia alters energy flow through marine food webs. Typically, 25-75\% of macrobenthic carbon biomass is transferred to higher level consumers (e.g., fish populations) when oxygen levels are sufficiently high to support aerobic metazoan animal populations. As oxygen levels decline, higher-level predation decreases and the proportion of benthic energy transferred to microbes increases until microbes process all benthic energy under anoxic conditions with hydrogen sulfide $\left(\mathrm{H}_{2} \mathrm{~S}\right)$ production (adapted from Diaz and Rosenberg, 2008). 
should be managed since $\mathrm{P}$ has been found to be the primary limiting nutrient in some coastal ecosystems (e.g., the NA), and managing only $\mathrm{N}$ without managing $\mathrm{P}$ inputs can lead to decreases in N:P ratios, increases in N-fixation, and toxic blooms of cyanobacteria (Conley et al., 2009; Glibert et al., 2014; Paerl et al., 2016; Glibert and Burford, 2017).

Nutrient enrichment from diffuse sources generally account for most anthropogenic nutrient loading, especially in watersheds where industrial agriculture and fossil fuel combustion are prevalent. While significant progress has been made in reducing nutrient inputs to coastal waters from point sources through tertiary waste water treatment ${ }^{27}$, reducing nutrient inputs from diffuse sources has proven to be much more difficult, especially in large watersheds (Boesch, 2019). In addition, rates of recovery in response to management actions to control diffuse inputs are often slow in coastal ecosystems, making it more difficult to relate cause and effect, a problem that is compounded by hysteresis in the trajectories of the processes of eutrophication and oligotrophication, i.e., for the same nutrient input, ecosystems are structured differently on the eutrophication trajectory than on the subsequent oligotrophication trajectory so they may not return to the same initial state (Duarte et al., 2009; Jochimsen et al., 2013; McCrackin et al., 2017; Duarte and Krause-Jensen, 2018).

\section{Management Response Strategies in the United States, the EU, and China \\ United States}

The 1998 National Strategy for the Development of Regional Nutrient $\mathrm{Criteria}^{28}$ presented an approach the U.S. Environmental Protection Agency (EPA) now uses to work with States and Tribes to adopt nutrient criteria as part of State water quality standards. Each State is required to submit a list of impaired and threatened waters within their jurisdiction and to establish priorities for the formulation of "Total Maximum Daily Loads" (TMDLs) of nutrients and other pollutants to these water bodies ${ }^{29}$. Implementation by each State may occur via direct management actions and water quality trading programs $s^{30}$. In addition to TMDLs, the EPA funds state-level diffuse source management programs that incorporate "Best Management Practices" (BMPs) (Liu et al., 2017). BMPs can be implemented to reduce nutrient loading from urban sources by using detention basins, constructed wetlands, vegetative swales $^{31}$, and rain

\footnotetext{
${ }^{27}$ An advanced treatment process that effectively removes most inorganic nutrients ( $\mathrm{N}$ and $\mathrm{P}$ ) and, in so doing, improves the quality of wastewater before it is discharged or recycled.

${ }^{28} \mathrm{https} / /$ www.epa.gov/sites/production/files/2018-10/documents/nutrientstrategy-1998.pdf (Accessed April 21, 2020).

${ }^{29} \mathrm{https}: / /$ fas.org/sgp/crs/misc/R42752.pdf (Accessed April 21, 2020).

${ }^{30} \mathrm{https} / / /$ www.epa.gov/chesapeake-bay-tmdl/trading-and-offsets-chesapeakebay-watershed (Accessed April 21, 2020).

${ }^{31}$ Broad, shallow channels designed to convey and infiltrate storm water runoff. Swales are vegetated along the bottom and sides of the channel, with side vegetation at a height greater than the maximum expected volume flow of storm water.
}

gardens. A critical BMP for agricultural fields is to improve nutrient use efficiency, i.e., select the right fertilizer and tune applications to match plant requirements and reduce nutrient losses. BMPs also include contour farming ${ }^{32}$, crop rotation, cover crops, no tillage, grassed waterways, constructed wetlands, grade stabilization structures, and vegetated buffer strips.

However, implementation has been slow and uneven because it is not a legal requirement, funding is insufficient, and outcomes are uncertain due to time lags between management actions and improvements in trophic status and hysteresis. In addition, although technical tools and management practices exist for costeffective reductions in nutrient inputs, implementation remains the primary problem, which suggests that new policy approaches should be tried. A broader use of incentives, trading, and corporate stewardship is clearly needed.

\section{Europe}

Numerous policy instruments have been propagated in an effort to protect coastal ecosystems (Joint Research Centre [JRC], 2014). The Nitrates Directive ${ }^{33}$ is intended to protect water resources against nitrates from agricultural sources, and the Urban Waste Water Treatment Directive (UWWT) aims at controlling emissions of nitrogen and phosphorus from point sources such as urban sewage effluents (Joint Research Centre [JRC], 2014). They both support the Water Framework Directive (WFD) that aims to achieve Good Ecological Status of water, including coastal waters, by 2020 (Pulido-Velazquez and Ward, 2017). The Marine Strategy Framework Directive has a specific descriptor focused on eutrophication to achieve Good Environmental Status in marine waters. These legal instruments are further complemented by international initiatives of Regional Seas that aim to control pollution from land-based sources and maritime transport, e.g., the Convention for the Protection of the Marine Environment of the North-East Atlantic (OSPAR), the Helsinki Convention on the Protection of the Marine Environment of the Baltic Sea Area (HELCOM, 2018b), and the Convention for the Protection of the Mediterranean Sea (Barcelona Convention).

However, despite numerous policy directives and conventions, the most recent assessment of trophic status of European coastal ecosystems (European Environmental Agency [EEA], 2018) shows that $40 \%$ of coastal (continental shelf) waters and $66 \%$ of transitional waters (estuaries) failed to achieve the objective of good ecological status ${ }^{34}$ (Poikane et al., 2019). Therefore, a new Fertilizing Products Regulation was adopted in 2019, and

\footnotetext{
${ }^{32}$ The practice of tilling sloped land along lines of consistent elevation in order to conserve rainwater and to reduce soil losses from surface erosion.

${ }^{33}$ The Nitrates Directive was adopted in 1991 to protect water quality across Europe by preventing nitrates from agricultural sources polluting ground and surface waters and by promoting the use of good farming practices.

${ }^{34}$ Indicators of good ecological status include the following: (i) Biodiversity is maintained; (ii) Non-indigenous species do not adversely alter the ecosystem; (iii) Populations of commercial fish species are healthy; (iv) Eutrophication is minimized; (v) Permanent alterations of hydrographic conditions do not adversely affect the ecosystem; (vi) Concentrations of contaminants give no ecological effects and concentrations in seafood are below safe levels; (vii) Marine litter does not cause harm; and (viii) Introduction of energy (including underwater sound) does not adversely affect the ecosystem.
} 
Carvalho et al. (2019), made the following recommendations to address the ongoing eutrophication problem:

(i) Changes in ecological status must be monitored and assessed more effectively;

(ii) Management actions must account for the effects of multiple stressors;

(iii) Management targets of the Water Framework Directive $(\mathrm{WDF})^{35}$ need to acknowledge long-term recovery timescales;

(iv) Water resource protection must be mainstreamed into other policy instruments; and

(v) WFD implementation must acknowledge management needs beyond 2027.

It is too early to assess whether these new EU fertilizer regulations will be effective, particularly in view of sometimes lengthy recovery times (O’Higgins et al., 2014).

\section{China}

The Chinese Government regards agriculture as the primary driver of economic development in the twenty-first century, and Chinese policy calls for implementing Integrated Nutrient Management (INM). The major challenge is how to increase crop production to meet food-demand while also increasing nutrient use efficiency (NUE) to protect the environment (Zhang F. et al., 2012). Nutrient management strategies have been successful in terms of maintaining maximum crop production, but attempts to improve NUE have been met with limited success in industrial agriculture. As a result, agricultural ecosystems are maintained in a state of nutrient saturation and are inherently leaky because chronic surplus additions of $\mathrm{N}$ and $\mathrm{P}$ have been used to maximize production.

INM was launched in 2005 with funding for 5 -years ( 6 billion Yuan or $\$ 923$ million US) (Zhang F. et al., 2012). The overall goal was to maximize both crop production and NUE by informing "root zone-rhizosphere management ${ }^{36}$ through soil testing and controlled fertilizer application. The objective is to manage soil nutrient supply in the root zone to match the quantity required for crop production. Rhizosphere management was proven to be an effective approach for increasing both crop productivity and NUE for sustainable agricultural production. However, there is still a long way to go to realize the objectives of NUE.

China's agricultural advisory system is fragmented (Ma et al., 2013). Increasing agricultural production is the primary role of the Ministry of Agriculture while environmental protection is the primary role of the Ministry of Environmental Protection. However, the Ministry of Agriculture has the greatest influence on farmers through financial incentives. In addition, regional Governors focus on industrial development and employment. As a result, regional governments often pay little attention to sustainable food production and environmental protection (Ma et al., 2013).

\footnotetext{
${ }^{35}$ https://ec.europa.eu/environment/water/water-framework/info/intro_en.htm (Accessed April 21, 2020).

${ }^{36}$ Rhizosphere management emphasizes maximizing the efficiency of rootrhizosphere processes in nutrient acquisition and use by crops rather than simply depending on excessive fertilizer inputs.
}

Fortunately, the Chinese Government is aware of the importance of INM to sustainable production and supports its adoption on a national scale. The key steps of INM are to (1) optimize inputs of anthropogenic nutrients by considering all possible nutrient sources, (2) match nutrient applications to crop requirement in this context, and (3) reduce $\mathrm{N}$ losses from industrial agriculture (Zhang F. et al., 2012). This has been a challenge given the transitions China has been going through in terms of both evolving from an agrarian society to an industrial society and from a government-led system to a marketled system. Adapting to these trends will require Governmental support for agriculture to deemphasize fertilizer-subsidies and increase direct support for farmers who can demonstrate that they are not only contributing to increases in food production but are also increasing NUE and environmental protection.

\section{The Way Forward}

Managing coastal eutrophication on regional to global scales requires both more comprehensive detection and monitoring of nutrient inputs and their impacts, especially, as noted in section "Global Trends and Patterns," in the southern hemisphere (Altieria et al., 2017; Diaz et al., 2019). In addition, efforts to reverse eutrophication and accelerate oligotrophication require more comprehensive strategies to reduce eutrophication than simply reducing nutrient inputs to coastal watersheds. These begin with ecosystem-based management plans that consider watersheds and their receiving bodies of water as a whole (e.g., large marine ecosystems) and, in this context, land-use practices that integrate landbased controls to manage nutrient releases and transports to coastal ecosystems (Carlson et al., 2019). Each part of the watershed plays a role in contributing to nutrient inputs, which are modulated by soil type, land use practices and land cover. Identifying critical source areas (CSAs) ${ }^{37}$ for cost effective nutrient control should be part of such an integrated approach (Pokhrel and Paudel, 2019).

Managing inputs of nutrients to watersheds and transports to coastal ecosystems can be augmented as needed. Examples include the following:

(i) Recycle animal manure to cropland within watersheds has been shown to be an effective BMP that substantially reduces nutrient runoff (Strokal et al., 2020);

(ii) Restore critical habitats (seagrass meadows, coral reefs, oyster reefs, mangrove forests and salt-marshes) to remove nutrients, increase sequestration of organic matter in benthic sediment, and increase rates of denitrification;

(iii) Establish sustainable macroalgal and bivalve aquaculture systems to remove excess $\mathrm{N}$ and $\mathrm{P}$ (Burkholder and Shumway, 2011; Kellogg et al., 2014; Duarte and KrauseJensen, 2018; Theuerkauf et al., 2019a,b; Kotta et al., 2020); and

\footnotetext{
${ }^{37}$ Critical source areas are areas within a watershed that contribute a disproportionately large amount of nutrients to the identified water quality problems. They are generally considered to be places where high-level nutrient sources coincide with high nutrient transport potential.
} 
(iv) Implement ecologically sound hydrological interventions to increase flushing and reduce the residence time of nutrients (Dettmann, 2001).

Given the challenges of controlling diffuse nutrient inputs and their impacts, two essential, mutually dependent activities must come into play to formulate, implement and improve cost-effective nutrient management strategies. First, repeated assessments of nutrient loading (sources and transportation routes) and impacts are needed that are informed by sustained and integrated research and monitoring (cf., Paerl, 2006; Carstensen, 2014; Malone et al., 2014). Second, these assessments must be enabled by ongoing guidance from scientists, politicians, managers and the public (Malone et al., 1993).

\section{REFERENCES}

Adolf, J. E., Stoecker, D. K., and Harding L. W. Jr. (2006). The balance of autotrophy and heterotrophy during mixotrophic growth of Karlodinium micrum (Dinophyceae). J. Plankton Res. 28, 737-751. doi: 10.1093/plankt/ fblo07

Allen, J. D., Richardson, E. L., Deaker, D., Agüera, A., and Byrne, M. (2019). Larval cloning in the crown-of-thorns sea star, a keystone coral predator. Mar. Ecol. Prog. Ser. 609, 271-276. doi: 10.3354/meps12843

Altieri, A. H., and Diaz, R.J. (2019). "Dead zones: Oxygen depletion in coastal ecosystems," in World Seas: An Environmental Evaluation, ed. C. Sheppard (Oxford: Elsevier Academic Press), 453-473. doi: 10.1016/b978-0-12-805052$1.00021-8$

Altieri, A. H., and Gedan, K. B. (2015). Climate change and dead zones. Glob. Change Biol. 21, 1395-1406. doi: 10.1111/gcb.12754

Altieria, A. H., Harrisona, S. B., Seemann, J., Collin, R., Diaz, R. J., and Knowlton, N. (2017). Tropical dead zones and mass mortalities on coral reefs, Proc. Nat. Acad. Sci. U.S.A. 114, 3660-3665. doi: 10.1073/pnas.162151 7114

Alvisi, F., and Cozzi, S. (2016). Seasonal dynamics and long-term trend of hypoxia in the coastal zone of Emilia Romagna (NW Adriatic Sea, Italy). Sci. Total Environ. 541, 1448-1462. doi: 10.1016/j.scitotenv.2015.10.011

Anderson, C. R., Moore, S. K., Tomlinson, M. C., Silke, J., and Cusack, C.K. (2015). "Living with harmful algal blooms in a changing world: strategies for modelling and mitigating their effects in coastal marine ecosystems," In Coastal and Marine Hazards, Risks, and Disasters, eds D. J. Sherman, J. Ellis, and J. F. Shroder (Amsterdam: Elsevier), 495-561. doi: 10.1016/b978-0-12-396483-0. 00017-0

Anderson, C. R., Siegel, D. A., Kudela, R. M., Brzezinskic, M. A. (2009). Empirical models of toxigenic Pseudo-nitzschia blooms: potential use as a remote detection tool in the Santa Barbara Channel. Harmful Algae 8, 478-492. doi: 10.1016/j.hal.2008.10.005

Anderson, D. M., Burkholder, J., Cochlan, W. P., Glibert, P. M., Gobler, C. J., Heil, C. A., et al. (2008). Harmful algal blooms and eutrophication: examining linkages from selected coastal regions of the United States. Harmful Algae 8, 39-53. doi: 10.1016/j.hal.2008.08.017

Anderson, D. M., Glibert, P. M., and Burkholder, J. M. (2002). Harmful algal blooms and eutrophication: nutrient sources, composition, and consequences. Estuar. Coasts 25, 704-726. doi: 10.1007/bf0280 4901

Aneja, V. P., Roelle, P. A., Murray, G. C., Southerland, J., Erismanc, J. W., David, F., et al. (2001). Atmospheric nitrogen compounds II: emissions, transport, transformation, deposition and assessment. Atmospheric Environ. 35, 19031911. doi: 10.1016/s1352-2310(00)00543-4

Aulenbach, B. T., Buxton, H. T., Battaglin, W. A., and Coupe, R. H. (2007). Streamflow and nutrient fluxes of the Mississippi-Atchafalaya River Basin and subbasins for the period of record through 2005: U.S. Geological Survey Open-File Report 2007-1080. Reston, VI: USGS.

\section{AUTHOR CONTRIBUTIONS}

TM and AN conceived, researched, and wrote this manuscript together. Both authors contributed to the article and approved the submitted version.

\section{ACKNOWLEDGMENTS}

This review has benefitted from the final draft of Chapter 10, Changes in Inputs to the Marine Environment of Nutrients, of the Second World Ocean Assessment to be published in late 2020 (Evans et al., 2019). AN acknowledges IMBeR, Future Earth Coasts and Future Earth Ocean KAN.

Barbier, E. B., Hacker, S. D., Kennedy, C., Koch, E. W., Stier, A. C., and Silliman, B. R. (2011). The value of estuarine and coastal ecosystem services. Ecol. Monogr., 81, 169-193.

Bargu, S., Baustian, M. M., Rabalais, N. N., del Rio, R., von Korff, B., and Turner, R. (2016). Influence of the Mississippi River on Pseudo-nitzschia spp. abundance and toxicity in Louisiana Coastal Waters. Estuar. Coasts 39, 1345-1356. doi: 10.1007/s12237-016-0088-y

Bauer, J. E., Cai, W. J., Raymond, P. A., Bianchi, T. S., Hopkinson, C. S., Regnier, P. A., et al. (2013). The changing carbon cycle of the coastal ocean. Nature 504, 61-70. doi: 10.1038/nature12857

Baustian, M. M., Rabalais, N. N., Del Rio, R., Von Korff, B., and Turner, R. E. (2016). Influence of the Mississippi River on Pseudo-nitzschia spp. abundance and toxicity in Louisiana coastal waters. Estuar. Coasts 39, $1345-1356$.

Bell, P. R. F. (1992). Eutrophication and coral reefs-some examples in the Great Barrier Reef lagoon. Water Res. 26, 553-568. doi: 10.1016/0043-1354(92) 90228-v

Bell, P. R. F., and Elmetri, I. (1995). Ecological indicators of largescale eutrophication in the Great Barrier Reef lagoon. Ambio 24, 208-215.

Bell, P. R. F., Elmetri, I., and Lapointe, B. E. (2014). Evidence of large-scale chronic eutrophication in the Great Barrier Reef: quantification of chlorophylla thresholds for sustaining coral reef communities. Ambio 43, 361-376. doi: 10.1007/s13280-013-0443-1

Bell, P. R. F., Elmetri, I., and Uwins, P. (1999). Nitrogen fixation of Trichodesmium spp. in the Great Barrier Reef Lagoon-importance to the overall nitrogen budget. Mar. Ecol. Prog. Ser. 186, 119-126. doi: 10.3354/meps1 86119

Benthuysen, J. A., Tonin, H., Brinkman, R., Herzfeld, M., and Steinberg, C. (2016). Intrusive upwelling in the Central Great Barrier Reef. J. Geophys. Res. Oceans 121, 8395-8416. doi: 10.1002/2016jc012294

Benway, H. M., and Coble, P. G. (Ed.) (2014). Report of The U.S. Gulf of Mexico Carbon Cycle Synthesis Workshop, March 27-28, 2013, Ocean Carbon and Biogeochemistry Program and North American Carbon Program, St. Petersburg, FL: Ocean Carbon \& Biogeochemistry, 67.

Bergström, L., Karlsson, M., Bergström, U., Pihl, L., and Kraufvelin, P. (2019). Relative impacts of fishing and eutrophication on coastal fish assessed by comparing a no-take area with an environmental gradient. Ambio 48, 565-579. doi: 10.1007/s13280-018-1133-9

Bernardi-Aubry, F., Berton, A., Bastianini, M., Socal, G., and Acri, F. (2004). Phytoplankton succession in a coastal area of the NW Adriatic, over a 10year sampling period. (1990-1999). Continental Shelf Res. 24, 97-115. doi: 10.1016/j.csr.2003.09.007

Bernhard, J. M., and Reimers, C. E. (1991). Benthic foraminiferal population fluctuations related to anoxia: santa Barbara Basin. Biogeochemistry 15, 127149.

Beusen, A. H. W., Bouwman, A. F., van Beek, L. P. H., Mogollón, J. M.,and Middelburg, J. J. (2016). Global riverine $\mathrm{N}$ and $\mathrm{P}$ transport to ocean 
increased during the 20th century despite increased retention along the aquatic continuum. Biogeosciences 13, 2441-2451. doi: 10.5194/bg-13-2441-2016

Beusen, A. H. W., Slomp, C. P., and Bouwman, A. F. (2013). Global land-ocean linkage: direct inputs of nitrogen to coastal waters via submarine groundwater discharge. Environ. Res. Lett. 8:034035. doi: 10.1088/1748-9326/8/3/034035

Bialonski, S., Caron, D. A., Schloen, J., Feudel, U., Kantz, H., Moorthi, S. D., et al. (2016). Phytoplankton dynamics in the Southern California Bight indicate a complex mixture of transport and biology. J. Plankton Res. 38, 1077-1091. doi: $10.1093 /$ plankt/fbv122

Bittman, S., and Mikkelsen, R. (2009). Ammonia emissions from agricultural operations: livestock. Better Crops 93, 28-31.

Blondeau-Patissier, D., Brando, V. E., Lønborg, C. Leahy, S.M., and Dekker, A. G. (2018). Phenology of Trichodesmium spp. blooms in the Great Barrier Reef lagoon, Australia, from the ESAMERIS 10-year mission. PLoS One 13:e0208010. doi: 10.1371 /journal.pone. 0208010

Bode, A., and Dortch, Q. (1996). Uptake and regeneration of inorganic nitrogen in coastal waters influenced by the Mississippi River: spatial and seasonal variations. J. Plankton Res. 18, 2251-2268. doi: 10.1093/plankt/18.12.2251

Boero, F., Brotz, L., Gibbons, M. J., Piraino, S., and Zampardi, S. (2016). "Impacts and effects of ocean warming on jellyfish," in Explaining Ocean Warming: Causes, Scale, Effects and Consequences, eds D. Laffoley and J.M. Baxter. Gland, International Union for Conservation of Nature, 213-237.

Boesch, D. F. (2019). Barriers and bridges in abating coastal eutrophication. Front. Mar. Sci. 6:123. doi: 10.3389/fmars.2019.00123

Bograd, S. J., Schwing, F. B., Castro, C. G., Timothy, D. A. (2002), Bottom water renewal in the Santa Barbara Basin. J. Geophys. Res. 107:3216. doi: 10.1029/ 2001JC001291

Booth, J. A. T., Woodson, C. B., Sutula, M A., Micheli, F., Weisberg, S. B., Bograd, S., et al. (2014). Patterns and potential drivers of declining oxygen content along the southern California coast. Limnol. Oceanogr. 59, 1127-1138. doi: 10.4319/lo.2014.59.4.1127

Bouwman, L., Goldewijk, K. K., Van Der Hoek, K. W., Beusen, A. H. W., Van Vuuren, D. P., and Willems, J., et al. (2013). Exploring global changes in nitrogen and phosphorus cycles in agriculture induced by livestock production over the 1900-2050 period. Proc. Natl. Acad. Sci. U.S.A. 110, 20882-20887. doi: $10.1073 /$ pnas. 1012878108

Bowen, R. E., and Riley, C. (2003). Socio-economic indicators and integrated coastal management. Ocean Coast. Manag., 46, 299-312. doi: 10.1016/s09645691(03)00008-5

Boyer, E. W., and Howarth, R. W. (2008). "Nitrogen fluxes from rivers to the coastal oceans," in Nitrogen in the Marine Environment, eds D. G. Capone, D. A. Bronk, M. R. Mulholland and E. J. Carpenter (Cambridge, MA: Academic Press), 1565-1587. doi: 10.1016/b978-0-12-372522-6.00036-0

Boynton, W. R., Garber, J. H., Summers, R., and Kemp, W. M. (1995). Inputs, transformations, and transport of nitrogen and phosphorus in Chesapeake Bay and selected tributaries. Estuaries 18, 285-314.

Boynton, W. R., and Kemp, W. M. (2000). Influence of river flow and nutrient loading on selected ecosystem processes: A synthesis of Chesapeake Bay data, in Estuarine Science: A Synthetic Approach to Research and Practice, Ed. J. Hobbie (Washington, DC: Island Press), 269-298.

Breitburg, D., Levin, L. A., Oschlies, A., Grégoire, M., Chavez, F. P., Conley, D. J., et al. (2018). Declining oxygen in the global ocean and coastal waters. Science 359:eaam7240. doi: 10.1126/science.aam7240

Breitburg, D. L., Hondorp, D. W., Davias, L. A., Diaz, R. J. (2009). Hypoxia, nitrogen, and fisheries: integrating effects across local and global landscapes. Annu. Rev. Mar. Sci. 1, 329-349. doi: 10.1146/annurev.marine.010908.163754

Brodie, J., Déath, G., Devlin, M., Furnas, M., and Wright, M. (2007). Spatial and temporal patterns of near-surface chlorophyll-a in the Great Barrier Reef lagoon. Mar. Freshw. Res. 58, 342-353.

Brodie, J., Lewis, S. E., Bainbridge, Z., Mitchell, A., Waterhouse, J., Kroon, F. J., et al. (2009). Target setting for pollutant discharge management in the Great Barrier Reef catchment area. Mar. Freshwater Res. 60, 1141-1149.

Brodie, J., Schroeder, T., Rohde, K., Faithful, J., Masters, B., Dekker, A. G., et al. (2010). Dispersal of suspended sediments and nutrients in the Great Barrier Reef lagoon during river-discharge events: conclusions from satellite remote sensing and concurrent flood-plume sampling. Mar. Freshwater Res. 61, 651664 .
Brodie, J., Wolanski, E., Lewis, S., and Bainbridge, Z. (2012). An assessment of residence times of land-sourced contaminants in the Great Barrier Reef lagoon and the implications for management and reef recovery. Mar. Pollut. Bull. 65, 267-279. doi: 10.1016/j.marpolbul.2011.12.011

Brodie, J. E., Devlin, M., Haynes, D., and Waterhouse, J. (2011). Assessment of the eutrophication status of the Great Barrier Reef lagoon (Australia). Biogeochemistry 106, 281-302. doi: 10.1007/s10533-010-9542-2

Brodie, J. E., and Mitchell, A. W. (2005). Nutrients in Australian tropical rivers: changes with agricultural development and implications for receiving environments. Mar. Freshwater Res. 56, 279-302.

Brotz, L., Cheung, W. W. L., Kleisner, K., Pakhomov, E., and Pauly, D. (2012). Increasing jellyfish populations: trends in large marine ecosystems. Hydrobiologia 690, 3-20. doi: 10.1007/978-94-007-5316-7_2

Brown, K. T., Bender-Champ, D., Kubicek, A., van der Zande, R., Achlatis, M., Hoegh-Guldberg, O., and Dove, S. G. (2018). The dynamics of coral-algal interactions in space and time on the southern Great Barrier Reef. Front. Mar. Sci. 5:181. doi: 10.3389/fmars.2018.00181

Brush, G. S. (2009). Historical land use, nitrogen, and coastal eutrophication: a paleoecological perspective. Estuar. Coasts 32, 18-28. doi: 10.1007/s12237-0089106-z

Brzezinski, M. A., and Washburn, L. (2011). Phytoplankton primary productivity in the Santa Barbara Channel: effects of wind-driven upwelling and mesoscale eddies, J. Geophys. Res., 116:C12013. doi: 10.1029/2011JC007397

Burkholder, J. M., and Shumway, S.E (2011). "Bivalve shellfish aquaculture and eutrophication," in Shellfish Aquaculture and the Environment, ed. S.E. Shumway (Hoboken, NY: John Wiley \& Sons, Inc.), 155-215. doi: 10.1002/ 9780470960967.ch7

Carlson, R. R., Foo, S. A., and Asner, G. P. (2019). Land use impacts on coral reef health: a ridge-to-reef perspective. Front. Mar. Sci. 6:562. doi: 10.3389/fmars. 2019.00562

Carstensen, J. (2014). Need for monitoring and maintaining sustainable marine ecosystem services. Front. Mar. Sci. 1:33. doi: 10.3389/fmars.2014.00033

Carstensen, J., Andersen, J. U., Gustafsson, B. G., and Conley, D. J. (2014). Deoxygenation of the Baltic Sea during the last century. Proc. Nat. Acad. Sci. U.S.A. 111, 5628-5633. doi: 10.1073/pnas.1323156111

Carvalho, L., Mackay, E. B., Cardoso, A. C., Baattrup-Pedersen, A., Birk, S., Blackstock, K. L., et al. (2019). Protecting and restoring Europe's waters: an analysis of the future development needs of the water framework directive. Sci. Total Environ. 658, 1228-1238. doi: 10.1016/j.scitotenv.2018.12.255

Chen, C. -C., Gong, G. -C., and Shiah, F. K. (2007). Hypoxia in the East China Sea: one of the largest coastal low-oxygen areas in the world. Mar. Environ. Res. 64, 399-408. doi: 10.1016/j.marenvres.2007.01.007

Chen, C.-T. (2008). Distributions of nutrients in the East China Sea and the South China Sea connection. J. Oceanogr. 64, 737-751. doi: 10.1007/s10872008-0062-69

Chen, C.-T. A. (1996). The Kuroshio intermediate water the major source of nutrients on the East China Sea continental shelf. Oceanol. Acta 19, 523-527.

Chen, J., Finlayson, B. L., Wei, T., Sun, Q, Webber, M., Li, M., and Chen, Z. (2016). Changes in monthly flows in the Yangtze River, China - With special reference to the Three Gorges Dam. J. Hydrol. 536, 293-301. doi: 10.1016/j.jhydrol.2016. 03.008

Chen, L., Liu, J., Xu, G., and Li, F. (2019). Phytoplankton productivity and community structure variations over the last 160 years in the East China Sea coast in response to natural and human-induced environmental changes. Holocene 29, 1145-1154. doi: 10.1177/09596836198 38040

Chesney, E. J., Baltz, D., and Thomas, G. (2000). Louisiana estuarine and coastal fisheries and habitats: perspectives from a fish's eye view. Ecol. Appl. 10, 350-366. doi: 10.1890/1051-0761(2000)010[0350:leacfa]2.0.co;2

Cloern, J. E. (1982). Does the benthos control phytoplankton biomass in South San Francisco Bay? Mar. Ecol. Prog. Ser. 9, 191-120.

Cloern, J. E. (2001). Our evolving conceptual model of the coastal eutrophication problem. Mar. Ecol. Prog. Ser. 210, 223-253. doi: 10.3354/meps210223

Cloern, J. E., Abreu, P. C., Carstensen, J., Chauvaud, L., Elmgren, R., and Grall, J. et al. (2016). Human activities and climate variability drive fast-paced change across the world's estuarine-coastal ecosystems. Glob. Change Biol. 22, 513-529. doi: $10.1111 / \mathrm{gcb} .13059$ 
Cloern, J. E., Foster, S. Q., and Kleckner, A. E. (2014). Phytoplankton primary production in the world's estuarine-coastal ecosystems. Biogeosciences 11, 24772501. doi: 10.5194/bg-11-2477-2014

Cloern, J. E., and Jassby, A. D. (2010). Patterns and scales of phytoplankton variability in estuarine-coastal ecosystems. Estuar. Coasts 33, 230-241. doi: 10.1007/s12237-009-9195-3

Committee on Environment and Natural Resources [CENR] (2000). Integrated Assessment of Hypoxia in the Northern Gulf of Mexico. Washington, DC: National Science and Technology Council.

Condon, R. H., Steinberg, D. K., del Giorgio, P. A., Bouvier, T. C., Bronk, D. A., Graham, W. M., and Ducklow, H. W. (2011). Jellyfish blooms result in a major microbial respiratory sink of carbon in marine systems. Proc. Nat. Acad. Sci. U.S.A. 108, 10225-10230. doi: 10.1073/pnas.101578 2108

Conley, D. J., Björck, S., Bonsdorff, E., Carstensen, J., Destouni, G., Gustafsson, B. G., et al. (2009). Hypoxia-related processes in the Baltic Sea. Environ. Sci. Technol. 43, 3412-3420.

Conley, D. J., and Malone, T. (1992). Annual cycle of dissolved silicate in Chesapeake Bay: implications for the production and fate of phytoplankton biomass. Mar. Ecol. Progr. Ser. 81, 121-128. doi: 10.3354/meps081121

Cooley, S. R. (2012). How human communities could 'feel' changing ocean biogeochemistry. Curr. Opin. Environ. Sustain. 4, 258-263. doi: 10.1016/j. cosust.2012.04.002

Corriero, G., Alabiso, G., Bavestrello, G., Barbone, E., Bastianini, M., Bazzoni, A., et al. (2016). Ecosystem vulnerability to alien and invasive species: a case study on marine habitats along the Italian coast. Aquatic Conserv. 26, 392-409.

Costantini, M., Ludsin, S. A., Mason, D. M., Zhang, X., Boicourt, W. C., and Brandt, S. B. (2008). Effect of hypoxia on habitat quality of striped bass (Morone saxatilis) in Chesapeake Bay. Can. J. Fish. Aquat. Sci. 65, 989-1002. doi: 10. 1139/f08-021

Costanza, R., de Groot, R., Braat, L., Kubiszewski, I., Fioramonti, L., Sutton, P., Farber, S., and Grasso, M. (2017). Twenty years of ecosystem services: how far have we come and how far do we still need to go? Ecosyst. Serv. 28, 1-16. doi: 10.1016/j.ecoser.2017.09.008

Costanza, R., de Groot, R., Sutton, P., der Ploeg, S., Anderson, S. J., Kubiszewski, I., Farber, S., and Turner, R. K. (2014). Changes in the global value of ecosystem services. Glob. Environ. Change 26, 152-158.

Cozzi, S., and Giani, M. (2011). River water and nutrient discharges in the Northern Adriatic Sea: current importance and long term changes. Cont. Shelf Res. 31, 1881-1893. doi: 10.1016/j.csr.2011.08.010

Crutzen, P. J. (2002). Geology of mankind: the Anthropocene. Nature 415:23. doi: $10.1038 / 415023 a$

Culhane, F. E., Frida, C. L. J., Gelabert, E. R., Piet, G., White, L., and Robinson, L. A. (2020). Assessing the capacity of European regional seas to supply ecosystem services using marine status assessments. Ocean Coast. Manag. 190:105154.

Dagg, M. J. (1995). Copepod grazing and the fate of phytoplankton in the northern Gulf of Mexico. Continental Shelf Res. 15, 1303-1317. doi: 10.1016/02784343(94)00086-3

Dagg, M. J., Ammerman, J. W., Amon, R. M. W., Gardner, W. S., Green, R. E., and Lohrenz, S. E. (2007). A review of water column processes influencing hypoxia in the Northern Gulf of Mexico. Estuar. Coasts 30, 735-752. doi: $10.1007 / \mathrm{bf} 02841331$

Dagg, M. J., and Breed, G. A. (2003). Biological effects of Mississippi River nitrogen on the Northern Gulf of Mexico - a review and synthesis. J. Mar. Syst. 43, 133-152. doi: 10.1016/j.jmarsys.2003.09.002

Dalsgaard, T., Brabandere, L. D., and Hall, P. O. J. (2013). Denitrification in the water column of the central Baltic Sea. Geochim. Cosmochim. Acta 106, 247-260. doi: 10.1016/j.gca.2012.12.038

Dalsgaard, T., Thamdrup, B., and Canfield, D. E. (2005). Anaerobic ammonium oxidation (anammox) in the marine environment. Res. Microbiol. 156, 457-464. doi: 10.1016/j.resmic.2005.01.011

D'Angelo, C., and Wiedenmann, J. (2014). Impacts of nutrient enrichment on coral reefs: new perspectives and implications for coastal management and reef survival. Curr. Opin. Environ. Sustain. 7, 82-93. doi: 10.1016/j.cosust.2013.11. 029

Danovaro, R., Fonda Umani, S., and Pusceddu, A. (2009). Climate change and the potential spreading of marine mucilage and microbial pathogens in the Mediterranean Sea. PLoS One 4:e7006. doi: 10.1371/journal.pone.0007006
Davidson, E. A. (2009). The contribution of manure and fertilizer nitrogen to atmospheric nitrous oxide since 1860. Nat. Geosci. 2, 659-662. doi: 10.1038/ ngeo608

de Mutser, K., Steenbeek, J., Lewis, K., Buszowski, J., Cowan J. H. Jr., and Christensen, V. (2016). Exploring effects of hypoxia on fish and fisheries in the northern Gulf of Mexico using a dynamic spatially explicit ecosystem model. Ecol. Model. 331, 142-150. doi: 10.1016/j.ecolmodel.2015.10.013

De'ath, G., and Fabricius, K. (2010). Water quality as a regional driver of coral biodiversity and macroalgae on the Great Barrier Reef. Ecol. Appl. 20, 840-850. doi: 10.1890/08-2023.1

Deegan, L. A., Johnson, D. S., and Warren, R. S. (2012). Coastal eutrophication as a driver of salt marsh loss. Nature 490, 388-392. doi: 10.1038/nature11533

Degobbis, D. (1989). Increased eutrophication of the northern Adriatic sea: second act. Mar. Pollut. Bull. 20, 452-457. doi: 10.1016/0025-326x(89)90066-0

Degobbis, D., and Gilmartin, M. (1990). Nitrogen, phosphorus, and biogenic silicon budgets for the northern Adriatic Sea. Oceanol. ACTA 13, 31-45.

Degobbis, D., Precali, R., Ferrari, C. R., Djakovac, T., Rinaldi, A., Ivancić, I., Gismondi, M., and Smodlaka, N. (2005). Changes in nutrient concentrations and ratios during mucilage events in the period 1999-2002. Sci. Total Environ. 353 (1-3),103-114. doi: 10.1016/j.scitotenv.2005.09.010

Degobbis, D., Precali, R., Ivančić, I., Smodlaka, N., Fuks, D., and Kveder, S. (2000). Long-term changes in the northern Adriatic ecosystem related to anthropogenic eutrophication. Int. J. Environ. Pollut. 13, 495-533.

Deininger, A., and Frigstad, H. (2019). Reevaluating the role of organic matter sources for coastal eutrophication, oligotrophication, and ecosystem health. Front. Mar. Sci. 6:210. doi: 10.3389/fmars.2019.00210

Dentener, F., Drevet, J., Lamarque, J. F., Bey, I., Eickhout, B., and Fiore, A. M., et al. (2006). Nitrogen and sulfur deposition on regional and global scales: a multimodel evaluation. Glob. Biogeochem. Cycles 20:GB4003. doi: 10.1029/ 2005GB002672

Dettmann, E. H. (2001). Effect of water residence time on annual export and denitrification of nitrogen in estuaries: a model analysis. Estuaries 24, 481-490.

Devlin, M., and Brodie, J. (2005). Terrestrial discharge into the Great Barrier Reef lagoon: nutrient behaviour in coastal waters. Mar. Pollut. Bull. 51, 9-22. doi: 10.1016/j.marpolbul.2004.10.037

Devlin, M., and Schaffelke, B. (2009). Extent and exposure of riverine flood plumes in the Tully coastal region. Mar. Freshw. Res. 60, 1109-1122.

Devlin, M. J., Petus, C., da Silva, E., Tracey, D., Wolff, N. H., Waterhouse, J., and Brodie, J. (2015). Water quality and river plume monitoring in the Great Barrier Reef: an overview of methods based on ocean colour satellite data. Remote Sens. 7, 12909-12941. doi: 10.3390/rs71012909

Diaz, R. J., and Rosenberg, R. (1995). Marine benthic hypoxia: a review of its ecological effects and the behavioural responses of benthic macrofauna. Oceanogr. Mar. Biol. Ann. Rev. 33, 245-303.

Diaz, R. J., and Rosenberg, R. (2008). Spreading dead zones and consequences for marine ecosystems. Science 321, 926-929. doi: 10.1126/science.1156401

Diaz, R. J., Rosenberg, R., and Sturdivant, K. (2019). "Hypoxia in estuaries and semi-enclosed seas", in Ocean Deoxygenation: Everyone's Problem - Causes, Impacts, Consequences and Solutions, eds D. Laffoley and J.M. Baxter (Gland: IUCN), 85-102.

Djakovac, T., Supić, N., Bernardi Aubry, F., Degobbis, D., and Giani, M. (2015). Mechanisms of hypoxia frequency changes in the northern Adriatic Sea during the period 1972-2012. J. Mar. Syst. 141, 179-189. doi: 10.1016/j.jmarsys.2014. 08.001

Dong, Z., Liu, D., and Keesing, J. K. (2010). Jellyfish blooms in China: dominant species, causes and consequences. Mar. Pollut. Bull. 60, 954-963. doi: 10.1016/ j.marpolbul.2010.04.022

Dortch, Q., Robichaux, R., Pool, S., Milsted, D., Mire, G., Rabalais, N. N., et al. (1997). Abundance and vertical flux of Pseudo-nitzschia in the northern Gulf of Mexico. Mar. Ecol. Progr. Ser. 146, 249-264. doi: 10.3354/meps146249

Du, J., and Shen, J. (2016). Water residence time in Chesapeake Bay for 1980-2012. J. Mar. Systems 164, 101-111. doi: 10.1016/j.jmarsys.2016.08.011

Duarte, C. M., Conley, D. J., Carstensen, J., and Sánchez-Camacho, M. (2009). Return to never land: shifting baselines affect eutrophication restoration targets. Estuar. Coasts 32, 29-36. doi: 10.1007/s12237-008-9111-2

Duarte, C. M., and Krause-Jensen, D. (2018). Intervention options to accelerate ecosystem recovery from coastal eutrophication. Front. Mar. Sci. 5:470. doi: $10.3389 /$ fmars.2018.00470 
Duce, R. A., LaRoche, J., Altieri, K., Arrigo, K. R., Baker, A. R., Capone, D. G., et al. (2008). Impacts of atmospheric anthropogenic nitrogen on the open ocean. Science 320, 893-897.

Dugdale, R. C., and Goering, J. J. (1967). Uptake of new and regenerated forms of nitrogen in primary productivity, Limnol. Oceanogr. 12, $196-206$.

Duncombe, J. (2018). Just how anomalous is the vast Baltic Sea dead zone?*, Eos 99, doi: 10.1029/2018EO103455

Dunn, D. D. (1996). Trends in Nutrient Inflows to the Gulf of Mexico from Streams Draining the Conterminous United States, 1972-93. Water Resour. Invest. Report 96:4113. DOI 10.3133/wri964113

Eero, M., Andersson, H. C., Almroth-Rosell, E., and MacKenzie, B. R. (2016). Has eutrophication promoted forage fish production in the Baltic Sea? Ambio 45, 649-660. doi: 10.1007/s13280-016-0788-3

Ekstrom, J. A., Suatoni, L., Cooley, S. R., Pendleton, L. H., Waldbusser, G. G., Cinner, J. E., et al. (2015). Vulnerability and adaptation of US shellfisheries to ocean acidification. Nat. Clim. Change 5, 207-214. doi: 10.1038/nclimate2508

Elliff, C. I., and Kikuchi, R. K. P. (2015). The ecosystem service approach and its application as a tool for integrated coastal management. Nat. Conserv. Braz. J. Nat. Conserv. 13, 105-111. doi: 10.1016/j.ncon.2015.10.001

Elliott, M., Burdon, D., Atkins, J. P., Borja, A., Cormier, R., de Jonge, V. N., and Turner, R. K. (2017). And DPSIR begat DAPSI (W) R (M)! - unifying framework for marine environmental management. Mar. Pollut. Bull. 118(1-2), 27-40. doi: 10.1016/j.marpolbul.2017.03.049

Elmgren, R., Blenckner, T., and Andersson, A. (2015). Baltic Sea management: successes and failures. Ambio 44 (Suppl. 3), S335-S344.

Elofsson, K. (2010). The costs of meeting the environmental objectives for the Baltic Sea: a review of the literature. Ambio 39, 49-58. doi: 10.1007/s13280-0090005-8

Eriksson, B. K., Ljunggren, L., Sandström, A., Johansson, G., Mattila, J., Rubach, A., et al. (2009). Declines in predatory fish promote bloom-forming macroalgae. Ecol. Appl. 19, 1975-1988. doi: 10.1890/08-0964.1

European Commission (1991). Council Directive 91/271/EEC of 21 May 1991 concerning urban waste water treatment. O.J. L135, 30.5. Brussels: European Commission.

European Environmental Agency [EEA] (2018). European Waters, Assessment of Status and Pressures 2018. EEA Report 7/2018. Luxembourg: Publications Office of the European Union.

European Topic Center [ETC] (2016). European Assessment of Eutrophication Abatement Measures Across Land-Based Sources, Inland, Coastal and Marine Waters. ETC/ICM Technical Report 2/2016. Denmark: European Environmental Agency.

Evans, K., Chiba, S., Bebianno, M. J., Garcia-Soto, C., Ojaveer, H., and Park, C., et al. (2019). The Global Integrated World Ocean Assessment: linking observations to science and policy across multiple scales. Front. Mar. Sci. 6:298. doi: 10.3389/ fmars.2019.00298

Fedra, K. E., Ölscher, M., Scherübel, C., Stachowitsch, M., and Wurzian, R. S. (1976). On the ecology of a north Adriatic benthic community: distribution, standing crop and composition of the macrobenthos. Mar. Biol. 38, 129-145. doi: $10.1007 /$ bf00390766

Feng, Y., Friedrichs, M. A. M., Wilkin, J., Tian, H., Yang, Q., Hofmann, E. E., et al. (2015). Chesapeake Bay nitrogen ?uxes derived from a land-estuarine ocean biogeochemical modeling system: model description, evaluation, and nitrogen budgets. J. Geophys. Res. Biogeosci. 120, 1666-1695. doi: 10.1002/2015JG002931

Fennel, K., Hetland, R., Feng, Y., and DiMarco, S. (2011). A coupled physicalbiological model of the Northern Gulf of Mexico shelf: model description, validation and analysis of phytoplankton variability. Biogeosciences 8, 18811899. doi: 10.5194/bg-8-1881-2011

Fennel, K., and Testa, J. M. (2019). Biogeochemical controls on coastal hypoxia. Annu. Rev. Mar. Sci. 11, 105-130. doi: 10.1146/annurev-marine-010318095138

Fiori, E., Zavatarelli, M., Pinardi, N., Mazziotti, C., and Ferrari, C. R. (2016). Observed and simulated trophic index (TRIX) values for the Adriatic Sea basin. Nat. Hazards Earth Syst. Sci. 16, 2043-2054. doi: 10.5194/nhess-16-2043-2016

Fonda Umani, S., Beran, A., Parlato, S., Virgilio, D., Zollet, T., de Olazabal, A., et al. (2004). Noctiluca scintillans McCartney in the Northern Adriatic Sea: longterm dynamics, relationships with temperature and eutrophication, and role in the food web. J. Plankton Res. 26, 545-561. doi: 10.1093/plankt/fbh045
Fonda Umani, S., Ghirardelli, E., and Specchi, M. (1989). Gli episodi di "mare sporco" nell'Adriatico dal 1729 ai giorni nostri Regione Autonoma FriuliVenezia Giulia. Direzione Regionale dell' Ambiente Trieste 0178.

Francé, J., and Mozetič, P. (2006). Ecological characterization of toxic phytoplankton species (Dinophysis spp., Dinophyceae) in Slovenian mariculture areas (Gulf of Trieste, Adriatic Sea) and the implications for monitoring. Mar. Pollut. Bull. 52, 1504-1516. doi: 10.1016/j.marpolbul.2006. 05.012

Funkey, C. P., Conley, D. J., Reuss, N. S., Humborg, C., Jilbert, T., and Slomp, C. P. (2014). Hypoxia sustains cyanobacteria blooms in the Baltic Sea. Environ. Sci. Technol. 48, 2598-2602. doi: 10.1021/es404395a

Furnas, M., Alongi, D., McKinnon, D., Trott, L., and Skuza, M. (2011). Regionalscale nitrogen and phosphorus budgets for the northern $\left(14^{\circ} \mathrm{S}\right)$ and central $\left(17^{\circ} \mathrm{S}\right)$ Great Barrier Reef shelf ecosystem. Cont. Shelf. Res. 31, 1967-1990. doi: 10.1016/j.csr.2011.09.007

Furnas, M., Mitchell, A., Skuza, M., and Brodie J. (2005). In the other 90\%: phytoplankton responses to enhanced nutrient availability in the Great Barrier Reef Lagoon. Mar. Pollut. Bull. 51, 253-265. doi: 10.1016/j.marpolbul.2004.11. 010

Furnas, M. J., Mitchell, A., Skuza, M. (1997). "Shelf scale nitrogen and phosphorus budgets for the Central Great Barrier Reef (16-19 S)," in Proceedings of the 8th International Coral Reef Symposium, vol 1, eds H.A. Lessios and I.G. Macintyre (Panama City, Panama), 809-814.

Gallardi, D. (2014). Effects of bivalve aquaculture on the environment and their possible mitigation: a review. Fish. Aquac. J. 5:105. doi: 10.4172/2150-3508. 1000105

Galloway, J. N., Dentener, F. J., Capone, D. G., Boyer, E. W., Howarth, R. W., and Seitzinger, S. P., et al. (2004). Nitrogen cycles: past, present, and future. Biogeochemistry 70, 153-226.

Giani, M., Djakovac, T., Degobbis, D., Cozzi, S., Solidoro, C., and Fonda Umani, S. (2012). Recent changes in the marine ecosystems of the northern Adriatic Sea. Estuar. Coast. Shelf Sci. 115, 1-13. doi: 10.1016/j.ecss.2012.08.023

Giani, M., Savellia, F., Berto, D., Zangrando, V., Ćosović, B., and Vojvodić, V. (2005). Temporal dynamics of dissolved and particulate organic carbon in the northern Adriatic Sea in relation to the mucilage events. Sci. Total Environ. 353, 126-138. doi: 10.1016/j.scitotenv.2005.09.062

Glibert, P. M. (2017). Eutrophication, harmful algae and biodiversity - challenging paradigms in a world of complex nutrient changes. Mar. Pollut. Bull. 124, 591-606. doi: 10.1016/j.marpolbul.2017.04.027

Glibert, P. M., Al-Azri, A., Allen, J. I, Bouwman, A. F., Beusen, A.H.W., Burford, M.A. et al. (2018). "Key questions and recent research advances on harmful algal blooms in relation to nutrients and eutrophication," in Global Ecology and Oceanography of Harmful Algal Blooms, eds P. Glibert, E. Berdalet, M. Burford, G. Pitcher, M. Zhou M. Ecological Studies (Berlin: Springer), 229-259. doi: 10.1007/978-3-319-70069-4_12

Glibert, P. M., and Burford, M. A. (2017). Globally changing nutrient loads and harmful algal blooms. Oceanography 30, 58-69. doi: 10.5670/oceanog.2017.110

Glibert, P. M., Magnien, R., Lomas, M. W., Alexander, J., Fan, C., and Erin, H., et al. (2001). Harmful algal blooms in the Chesapeake and coastal bays of Maryland, USA: comparison of 1997, 1998, and 1999 events. Estuaries 24, 875-883.

Glibert, P. M., Manager, R., Sobota, D. J., and Bouwman, L. (2014). The HaberBosch-harmful algal bloom (HB-HAB) link. Environ. Res. Lett. 9:105001. doi: 10.1088/1748-9326/9/10/105001

Glibert, P. M., Mayorga, E., and Seitzinger, S. (2008). Prorocentrum minimum tracks anthropogenic nitrogen and phosphorus inputs on a global basis: application of spatially explicit nutrient export models. Harmful Algae 8, 33-38. doi: 10.1016/j.hal.2008.08.023

Gobler, C. J., Doherty, O. M., Hattenrath-Lehmann, T. K., Griffith, A. W., Kang, Y., and Litaker, R. W. (2017). Ocean warming since 1982 has expanded the niche of toxic algal blooms in the North Atlantic and North Pacific oceans. Proc. Nat. Acad. Sci. U.S.A. 114, 4975-4980. doi: 10.1073/pnas.1619575114

Goldewijk, K. K., Beusen, A., van Drecht, G., and de Vos, M. (2011). The HYDE 3.1 spatially explicit database of human-induced global land-use change over the past 12,000 years. Glob. Ecol. Biogeogr. 20, 73-86. doi: 10.1111/j.1466-8238. 2010.00587.x

Gomez, F. A., Lee, S. -K., Liu, Y., Hernandez F. J. Jr., Muller-Karger, F. E., and Lamkin, J. T. (2018). Seasonal patterns in phytoplankton biomass across the 
northern and deep Gulf of Mexico: a numerical model study. Biogeosciences 15, 3561-3576. doi: 10.5194/bg-15-3561-2018

Goolsby, D. A., Battaglin, W. A., Lawrence, G. B., Artz, R. S., Aulenbach, B. T., Hooper, R. P., et al. (1999). "Flux and Sources of Nutrients in the MississippiAtchafalaya River Basin: Topic 3 Report for the Integrated Assessment of Hypoxia in the Gulf of Mexico," NOAA Coastal Ocean Program Decision Analysis Series No. 17*. (Silver Spring, MD: NOAA Coastal Ocean Office).

Green, P. A., Vörösmarty, C. J., Meybeck, M., Galloway, J. N., Peterson, B. J., and Boyer, E. W. (2004). Pre-industrial and contemporary fluxes of nitrogen through rivers: a global assessment based on typology. Biogeochemistry 68, 71-105. doi: 10.1023/b:biog.0000025742.82155.92

Gregg, W. W., Casey, N. W., and McClain, C. R. (2005). Recent trends in global ocean chlorophyll. Geophys. Res. Lett. 32:L030606. doi: 10.1029/2004GL021808

Große, F., Fennel, K., Zhang, H., and Laurent, A. (2020). Quantifying the contributions of riverine vs. oceanic nitrogen to hypoxia in the East China Sea. Biogeosciences 17, 2701-2714. doi: 10.5194/bg-17-2701-2020

Gruber, N., and Galloway, J. (2008). An Earth-system perspective of the global nitrogen cycle. Nature 451: 293-296 (doi: 10.1038/nature06592)

Gustafsson, B. G., Schenk, F., Blenckner, T., Eilola, K., Meier, H. E. M., MüllerKarulis, B., et al. (2012). Reconstructing the development of Baltic Sea eutrophication 1850-2006. Ambio 41, 534-548. doi: 10.1007/s13280-0120318-x

Gustafsson, B. G., and Westman, P. (2002). On the causes for salinity variations in the Baltic Sea during the last 8500 years. Paleoceanograph 17, 12-11.

Halpern, B., Walbridge, S., Selkoe, K. A., Kappel, C. V., Micheli, F., D’Agrosa, C., et al. (2008). A global map of human impact on marine ecosystems. Science 319, 948-952.

Harding, L. W. Jr., Mallonee, M. E., and Perry, E. S. (2002). Toward a predictive understanding of primary productivity in a temperate, partially stratified estuary. Estuar. Coast. Shelf Sci. 55, 437-463. doi: 10.1006/ecss.2001.0917

Harding, L. W. Jr., Mallonee, M. E., Perry, E. S., Miller, W. D., Adolf, J. E., Gallegos, C. L., and Paerl, H. W. (2019). Long-term trends, current status, and transitions of water quality in Chesapeake Bay. Sci. Rep. 9, 6709-6728.

Harding, L.W. Jr, Degobbis, D.,and Precali, R. (1999). "Production and fate of phytoplankton: Annual cycles and interannual variability," in Ecosystems at the Land-Sea Margin: Drainage Basin to the Coastal Sea, eds T.C. Malone, A. Malej, L.W. Harding, and N. Smodlaka, (Washington, DC: AGU), 131-172. doi: 10.1029/ce055p0131

Harding L. W. Jr., Mallonee, M. E., Perry, E. S., Miller, D., Adolf, J. E., Gallegos, C. L., and Paerl, H. W. (2020). Seasonal to inter-annual variability of primary production in Chesapeake Bay: prospects to reverse eutrophication and change trophic classification. Sci. Rep. 10:2019. doi: 10.1038/s41598-020-58702-3

Harris, G. P. (2001). Biogeochemistry of nitrogen and phosphorus in Australian catchments, rivers and estuaries: effects of land use and flow regulation and comparisons with global patterns. Mar. Freshw. Res. 52, 139-149.

Heil, C. A., Glibert, P. M., and Fan, C. (2005). Prorocentrum minimum (Pavillard) Schiller. A review of a harmful algal bloom species of growing worldwide importance. Harmful Algae 4, 449-470. doi: 10.1016/j.hal.2004.08.003

Heisler, J., Glibert, P., Burkholder, J., Anderson, D., Cochlan, W., and Dennison, W. et al. (2008). Eutrophication and harmful algal blooms: a scientific consensus. Harmful Algae 8, 3-13. doi: 10.1016/j.hal.2008.08.006

HELCOM (2009). Eutrophication in the Baltic Sea - An integrated thematic assessment of the effects of nutrient enrichment and eutrophication in the Baltic Sea region. Baltic Sea Environ. Proc. No. 115B. Helsinki: HELCOM.

HELCOM (2011). The Fifth Baltic Sea Pollution Load Compilation (PLC-5) Baltic Sea Environ. Proc. No. 128. Helsinki: HELCOM.

HELCOM (2018a). HELCOM Thematic assessment of eutrophication 2011-2016. Baltic Sea Environ. Proc. No. 156. Helsinki: HELCOM.

HELCOM (2018b). "Implementation of the Baltic Sea Action Plan 2018: Three years left to good environmental status," in Proceedings of the Brussels Ministerial Meeting, (Brussels:Baltic Marine Environment Protection Commission).

Hetland, R. D., and Campbell, L. (2007). Convergent blooms of Karenia brevis along the Texas coast. Geophys. Res. Lett. 34:L19604. doi: 10.1029/ 2007GL030474

Hieronymus, J., Eilola, K., Hieronymus, M., Meier, H. E. M., Saraiva, S., and Karlson, B. (2018). Causes of simulated long-term changes in phytoplankton biomass in the Baltic proper: a wavelet analysis. Biogeosciences 15, 5113-5129. doi: 10.5194/bg-15-5113-2018

Hirsch, R. M. (2012). Flux of Nitrogen, Phosphorus, and Suspended Sediment from the Susquehanna River Basin to the Chesapeake Bay during Tropical Storm Lee, September 2011, as an Indicator of the Effects of Reservoir Sedimentation on Water Quality. U.S. Geological Survey Scientific Investigations Report 20125185. (Reston, VI: USGS).

Hoagland, P. and Scatasta, S. (2006). "The economic effects of harmful algal blooms," in Ecology of Harmful Algae, eds E. Granéli and J.T. Turner, (New York, NY, Springer-Verlag) 391-402. doi: 10.1007/978-3-540-32210-8_ 30

Hoegh-Guldberg, O., and Bruno, J. F. (2010). The impact of climate change on the world's marine ecosystems. Science 328, 1523-1528. doi: 10.1126/science. 1189930

Hoegh-Guldberg O, Poloczanska ES, Skirving W, and Dove S. (2017). Coral reef ecosystems under climate change and ocean acidification. Front. Mar. Sci. 4:158. doi: 10.3389/fmars.2017.00158

Honsell, G., Poletti, R., and Pompei, M. (1996). "Alexandrium minutum Halim and PSP contamination in the northern Adriatic Sea (Mediterranean Sea)," in Harmful and Toxic Algal Blooms, Proceedings of the 7th International Conference of Toxic Phytoplankton, Sendai, Japan, eds T. Yasumoto, Y. Oshima, and Y. Fukuyo (Paris: UNESCO-IOC), 77-80.

Hopkins, T. S. (1999). Physical control of the eutrophic response in the northern Adriatic Sea, illustrated by a nitrogen budget from ELNA data. Eutrophic Limits of the Northern Adriatic. Ann. dell'Istit. Superiore Sanita 35, 355-363.

Hordoir, R., and Meier, H. E. (2010). Freshwater fluxes in the Baltic Sea: a model study, J. Geophys. Res. 115:C08028. doi: 10.1029/2009JC005604

Howard, M. D. A., Kudela, R. M., and McLaughlin, K. (2017). New insights into impacts of anthropogenic nutrients on urban ecosystem processes on the Southern California coastal shelf: introduction and synthesis. Estuar. Coast. Shelf Sci. 186, 163-170. doi: 10.1016/j.ecss.2016.06.028

Howarth, R. W. (1998). An assessment of human influences on inputs of nitrogen to the estuaries and continental shelves of the North Atlantic Ocean. Nutr. Cycl. Agroecosyst. 52, 213-223.

Howarth, R. W. (2008). Coastal nitrogen pollution: a review of sources and trends globally and regionally. Harmful Algae 8, 14-20. doi: 10.1016/j.hal.2008.08.015

Howarth, R. W., Billen, G., and Swaney, D. (1996). Regional nitrogen budgets and riverine $\mathrm{N} \& \mathrm{P}$ fluxes for the drainages to the North Atlantic Ocean: natural and human influences. Biogeochemistry 35, 75-139. doi: 10.1007/978-94-009-177673

Howarth, R. W., and Marino, R. (2006). Nitrogen as the limiting nutrient for eutrophication in coastal marine ecosystems: evolving views over three decades. Limnol. Oceanogr. 51, 364-376. doi: 10.4319/lo.2006.51.1_part_2.0364

Huang, T.-H., Chen, C.-T. A., Lee, J., Wu, C.-R., Wang, Y.-L., Bai, Y., and He, X., et al. (2019). East China Sea increasingly gains limiting nutrient $P$ from South China Sea. Sci. Rep. 9:5648. doi: 10.1038/s41598-019-42020-42024

Huntington, T. G. (2006). Evidence for intensification of the global water cycle: review and synthesis. J. Hydrol. 319, 83-95. doi: 10.1016/j.jhydrol.2005.07.003

Imperial, M. T., and Hennessey, T. M. (1996). An ecosystem-based approach to managing estuaries: an assessment of the National Estuary Program. Coast. Manag. 24, 115-139. doi: 10.1080/08920759609362286

IPCC (2014). Climate Change 2014: Impacts, Adaptation, and Vulnerability. Part A: Global and Sectoral Aspects. Contribution of Working Group II to the Fifth Assessment Report of the Intergovernmental Panel on Climate Change, Cambridge: Cambridge University Press.

Jickells, T. D., Buitenhuis, E., Altieri, K., Baker, A. R., Capone, D., and Duce, R. A. et al. (2017). A reevaluation of the magnitude and impacts of anthropogenic atmospheric nitrogen inputs on the ocean. Glob. Biogeochem. Cycles 31, 289305.

Jochimsen, M. C., Kiimmerlin, R., and Straile, D. (2013). Compensatory dynamics and the stability of phytoplankton biomass during four decades of eutrophication and oligotrophication. Ecol. Lett. 16, 81-89. doi: 10.1111/ele. 12018

Johnson, A., and Harrison, M. (2015). The increasing problem of nutrient runoff on the coast. Am. Sci. 1003:98. doi: 10.1511/2015.113.98

Joint Research Centre [JRC] (2014). Managing Nitrogen, and Phosphorus Loads to Water Bodies: Characterization, and Solutions, Towards Macro-Regional 
Integrated Nutrient Management. Technical Report of the Joint Research Centre of the European Commission, (ISPRA: JRC).

Jokinen, S. A., Virtasalo, J. J., Jilbert, T., Kaiser, J., Dellwig, O., Arz, H. W., et al. (2018). A 1500-year multiproxy record of coastal hypoxia from the northern Baltic Sea indicates unprecedented deoxygenation over the 20th century. Biogeosciences 15, 3975-4001. doi: 10.5194/bg-15-3975-2018

Jørgensen, B. B., and Richardson, K. (eds) (1996). Eutrophication in Coastal Marine Ecosystems, Volume 52, Coastal and Estuarine Studies series, Washington, DC: American Geophysical Union. doi: 10.1029/CE052

Justić, D., Bierman, J. V., Scavia, D., and Hetland, D. R. (2007). Forecasting gulf's hypoxia: the next 30 years? Estuar. Coasts 30, 791-801. doi: 10.1007/bf02841334

Justić, D., Rabalais, N. N., and Turner, R. G. (1995). Stoichiometric nutrient balance and origin of coastal eutrophication. Mar. Pollut. Bull. 30, 41-46. doi: 10.1016/ 0025-326x(94)00105-i

Kellogg, M. L., Smyth, A. R., Luckenbach, M. W., Carmichael, R. H., Brown, B. L., and Cornwell, J. C. et al. (2014). Use of oysters to mitigate eutrophication in coastal waters. Estuar. Coast. Shelf Sci. 151, 156-168. doi: 10.1016/j.ecss.2014. 09.025

Kemp, W. M., Boynton, W. R., Adolf, J. E., Boesch, D. F., Boicourt, W. C., Brush, G., et al. (2005). Eutrophication of Chesapeake Bay: historical trends and ecological interactions. Mar. Ecol. Progr. Ser. 303, 1-29. doi: 10.3354/meps303001

Kerbrat, A. S., Amzil, Z., Pawlowiez, R., Golubic, S., Sibat, M., Darius, H. T., et al. (2011). First evidence of palytoxin and 42-Hydroxy-palytoxin in the marine cyanobacterium Trichodesmium. Mar. Drugs 9, 543-560. doi: 10.3390/ md 9040543

Kim, H.-C., Yamaguchi, H., Yoo, S., Zhu, J., Okamura, K., Kiyomoto, Y., et al. (2009). Distribution of Changjiang diluted water detected by the satellite chlorophyll-a and its interannual variation during 1998-2007, J. Oceanogr. 65, 129-135. doi: 10.1007/s10872-009-0013-0

Koch, E. W., Barbier, E. B., Silliman, B. R., Reed, D. J., Perillo, G. M. E., Hacker, S. D., et al. (2009). Non-linearity in ecosystem services: temporal and spatial variability in coastal protection. Front. Ecol. Environ. 7, 29-37. doi: 10.1890/ 080126

Kong, C. E., Yoo, S., and Jang, C. J. (2019). East China Sea ecosystem under multiple stressors: heterogeneous responses in the sea surface chlorophyll-a. Deep Sea Res. Part I, 151:103078. doi: 10.1016/j.dsr.2019.103078

Kotta, J., Futter, M., Kaasik, A., Liversage, K., Rätsep, M., Barboza, F. R., et al. (2020). Cleaning up seas using blue growth initiatives: mussel farming for eutrophication control in the Baltic Sea. Sci. Total Environ. 709:136144. doi: 10.1016/j.scitotenv.2019.136144

Kroon, F. J., Kuhnert, P. M., Henderson, B. L., Wilkinson, S. N., KinseyHenderson, A., Abbott, B., et al. (2012). River loads of suspended solids, nitrogen, phosphorus and herbicides delivered to the Great Barrier Reef lagoon. Mar. Poll. Bull. 65, 167-181. doi: 10.1016/j.marpolbul.2011.10.018

Kudela, R. M., Seeyave, S., and Cochlan, W. P. (2010). The role of nutrients in regulation and promotion of harmful algal blooms in upwelling systems. Progr. Oceanogr. 85, 122-135. doi: 10.1016/j.pocean.2010.02.008

Lamsal, L. N., Martin, R. V., Padmanabhan, A., van Donkelaar, A., Zhang, Q., Sioris, C. E., et al. (2011). Application of satellite observations for timely updates to global anthropogenic NOx emission inventories. Geophys. Res. Lett. 38:L05810. doi: 10.1029/2010GL046476

Laurent, A., Fennel, K., Ko, D. S., and Lehrter, J. (2018). Climate change projected to exacerbate impacts of coastal eutrophication in the northern Gulf of Mexico. J. Geophys. Res. Oceans 123, 3408-3426. doi: 10.1002/2017JC013583

Lee, R. Y., Seitzinger, S., and Mayorga, E. (2016). Land-based nutrient loading to LMEs: a global watershed perspective on magnitudes and sources. Environ. Dev. 17, 220-229. doi: 10.1016/j.envdev.2015.09.006

Levin, L. A., Ekau, W., Gooday, A. J., Jorissen, F., Middelburg, J. J., Naqvi, S. W. A., et al. (2009). Effects of natural and human-induced hypoxia on coastal benthos. Biogeosciences 6, 2063-2098. doi: 10.5194/bg-6-2063-2009

Levin, S. A., and Lubchenco, J. (2008). Resilience, robustness, and marine ecosystem-based management. Bioscience 58, 27-32. doi: 10.1641/b580107

Li, H-.M., Tang, H.-J., Shi, X. Y., Zhang, C-S., and Wang, X. L. (2014). Increased nutrient loads from the Changiiang (Yangtze) River have led to increased harmful algal blooms. Harmful Algae 39, 92-101. doi: 10.1016/j.hal.2014.07.002

Li, L., Jingyi, C., Lei, C., and Songhui, L. (2019). Response of size-fractionated phytoplankton to environmental factors near the Changjiang Estuary. Acta Oceanol. Sin. 38, 151-159. doi: 10.1007/s13131-018-1259-4
Li, M., Lee, Y. J., Testa, J. M., Li, Y., Ni, W., Kemp, W. M., and Di Toro, D. M. (2016). What drives interannual variability of estuarine hypoxia: climate forcing versus nutrient loading? Geophys. Res. Lett. 43, 2127-2134. doi: 10.1002/ $2015 \mathrm{gl} 1067334$

Li, X., Yu, Z., Song, X., Cao, X., and Yuan, Y. (2011). The seasonal characteristics of dissolved oxygen distribution and hypoxia in the Changjiang Estuary. J. Coast. Res. 27, 52-62. doi: 10.2112/jcoastres-d-11-00013.1

Li, Y., Li, M., and Kemp, W. M. (2015). A budget analysis of bottom-water dissolved oxygen in Chesapeake Bay. Estuar. Coasts 38, 2132-2148. doi: 10.1007/s12237014-9928-9

Liblik, T., and Lips, U. (2019). Stratification has strengthened in the Baltic Sea An analysis of 35 years of observational data. Front. Earth Sci. 7:174. doi: 10.3389/feart.2019.00174

Lignell, R., Heiskanen, A.-S., Kuosa, H., Gundersen, K., Kuuppo-Leinikki, P., Pajuniemi, R., et al. (1993). Fate of a phytoplankton spring bloom: sedimentation and carbon flow in the planktonic food web in the northern Baltic. Mar. Ecol. Prog. Ser. 94, 239-252. doi: 10.3354/meps094239

Limburg, K. E., and Casini, M. (2019). Otolith chemistry indicates recent worsened Baltic cod condition is linked to hypoxia exposure. Biol. Lett. 15:20190352. doi: $10.1098 /$ rsbl.2019.0352

Lin, C. H., Lyubchich, V., and Glibert, P. M. (2018). Time series models of decadal trends in the harmful algal species Karlodinium veneficum in Chesapeake Bay. Harmful Algae 73, 110-118. doi: 10.1016/j.hal.2018.02.002

Lin, X., Liu, M., Hou, L., Gao, D., Li, X., Lu, K., et al. (2017). Nitrogen losses in sediments of the East China Sea: spatiotemporal variations, controlling factors, and environmental implications. J. Geophys. Res. Biogeosci. 122, 2699-2715. doi: 10.1002/2017jg004036

Lipizer, M., Cabrini, M., Fornasaro, D., Kralj, M., Giani, M., and Mosetti, R. (2017). Harmful algal frequency over the last 30 years in the Gulf of Trieste. Biol. Mar. Mediterr. 24, 43-48.

Liu, K.-K., Yan, W., Lee, H.-J., Chao, S.-Y., Gong, G. C., and Yeh, T.-Y. (2015). Impacts of increasing dissolved inorganic nitrogen discharged from Changjiang on primary production and seafloor oxygen demand in the East China Sea from 1970 to 2002. J. Mar. Syst. 141, 200-217. doi: 10.1016/j.jmarsys.2014.07.022

Liu, S. M., Zhang, J., Chen, H. T., Wu, Y., Xiong, H., and Zhang, Z. F. (2003). Nutrients in the Changjiang and its tributaries. Biogeochemistry 62, $1-18$.

Liu, Y., Engel, B. A., Flanagan, D. C., Gitau, M. W., McMillan, S. K., and Chaubey, I. (2017). A review on effectiveness of best management practices in improving hydrology and water quality: needs and opportunities. Sci. Total Environ. 60, 580-593. doi: 10.1016/j.scitotenv.2017.05.212

Lohrenz, S. E., Fahnenstiel, G. L., Redalje, D. G., Lang, G. A., Chen, X., and Dagg, M. J. (1997). Variations in primary production of northern Gulf of Mexico continental shelf waters linked to nutrient inputs from the Mississippi River. Mar. Ecol., Prog. Ser. 155, 45-54. doi: 10.3354/meps155045

Lohrenz, S. E., Fahnenstiel, G. L., Redalje, D. G., Lang, G. A., Dagg, M. J., Whitledge, T. E., et al. (1999). Nutrients, irradiance, and mixing as factors regulating primary production in coast waster impacted by the Mississippi River plume. Cont. Shelf Res. 19, 1113-1141. doi: 10.1016/s0278-4343(99)00012-6

Lu, C., and Tian, H. (2017). Global nitrogen and phosphorus fertilizer use for agriculture production in the past half century: shifted hot spots and nutrient imbalance. Earth Syst. Sci. Data 9, 181-192. doi: 10.5194/essd-9-181-2017

Lu, D., Yuzao, Q., Gu, H., Dai, X., Wang, H., and Gao, Y. (2014). Causative species of harmful algal blooms in Chinese coastal waters. Algol. Stud. 145, 145-168. doi: 10.1127/1864-1318/2014/0161

Ma, L., Zhang, W. F., Ma, W. Q., Velthof, G. L., Oenema, O., Zhang, F. S., et al. (2013). An analysis of developments and challenges in nutrient management in China. J. Environ. Qual. 42, 951-961. doi: 10.2134/jeq2012.0459

Mackey, K. R. M., Kavanaugh, M. T., Wang, F., Chen, Y., Liu, F., Glover, D. M., et al. (2017). Atmospheric and fluvial nutrients fuel algal blooms in the East China Sea. Front. Mar. Sci. 4:2. doi: 10.3389/fmars.2017.00002

Malone, T. C. (1991). River flow, phytoplankton production, and oxygen depletion in Chesapeake Bay. J. Geol. Soc. Special Publ. 58, 83-93. doi: 10.1144/gsl.sp. 1991.058.01.06

Malone, T. C., Boynton, W., Horton, T., and Stevenson, C. (1993). "Nutrient loadings to surface waters: chesapeake bay case study," in Keeping Pace with Science and Engineering: Case Studies in Environmental Regulation, ed. M. F. Uman (Washington, D.C: National Academy Press), 8-38. 
Malone, T. C., Conley, D. J., Fisher, T. R., Glibert, P. M., Harding, L. W., and Sellner, K. G. (1996). Scales of nutrient limited phytoplankton productivity in Chesapeake Bay. Estuaries 19, 371-385.

Malone, T. C., Crocker, L. H., Pike, S. E., and Wendler, B. W. (1988). Influences of river flow on the dynamics of phytoplankton production in a partially stratified estuary. Mar. Ecol. Progr. Ser. 48, 235-249. doi: 10.3354/meps04 8235

Malone, T. C., DiGiacomo, P. M., Gonçalves, E., Knap, A. H., Talaue-McManus, L., and de Mora, S. (2014). A global ocean observing system framework for sustainable development. Mar. Pol. 43, 262-272. doi: 10.1016/j.marpol.2013. 06.008

Marini, M., Jones, B. H., Campanelli, A., Grilli, F., and Lee, C. M. (2008). Seasonal variability and Po River plume influence on biochemical properties along western Adriatic coast. J. Geophys. Res. 113:C05S90. doi: 10.1029/ 2007JC004370

Marino, R., Chan, F., Howarth, R. W., Pace, M., and Likens, G. E. (2002). Ecological and biogeochemical interactions constrain planktonic nitrogen fixation in estuaries. Ecosystems 5, 719-725. doi: 10.1007/s10021-002-0176-7

Marshall, H. G., Lane, M. F., Nesius, K. K., and Burchardt, L. (2009). Assessment and significance of phytoplankton species composition within Chesapeake Bay and Virginia tributaries through a long-term monitoring program. Environ. Monit. Assess. 150, 143-155. doi: 10.1007/s10661-008-0680-0

Martínez, M. L., Intralawan, A., Vázquez, G., Pérez-Maqueo, O., Sutton, P., and Landgrave, R. (2007). The coasts of our world: ecological, economic and social importance. Ecol. Econ. 63, 254-272. doi: 10.1016/j.ecolecon.2006.10.022

Mazur-Marzec, H., and Pliñski, M. (2009). Do toxic cyanobacteria blooms pose a threat to the Baltic ecosystem? Oceanologia 51, 293-319. doi: 10.5697/oc.51-3. 293

McCrackin, M. L., Jones, H. P., Jones, P. C., and Moreno-Mateos, D. (2017). Recovery of lakes and coastal marine ecosystems from eutrophication: a global meta-analysis. Limnol. Oceanogr. 62, 507-518. doi: 10.1002/lno.10441

McKinney, F. K. (2007). The Northern Adriatic Ecosystem: Deep Time in a Shallow Sea. New York, NY: Columbia University Press.

McKinnon, A. D., Logan, M., Castine, S. A., and Duggan, S. (2013). Pelagic metabolism in the waters of the Great Barrier Reef. Limnol. Oceanogr. 58, 1227-1242. doi: 10.4319/lo.2013.58.4.1227

McPhee-Shaw, E. E., Siegel, D. A., Washburn, L., Brzezinski, M. A., Jones, J. L., Leydecker, A., et al. (2007). Mechanisms for nutrient delivery to the inner shelf: observations from the Santa Barbara Channel. Limnol. Oceanogr. 52, 1748-1766. doi: 10.4319/lo.2007.52.5.1748

Messer, L. F., Brown, M. V., Furnas, M. J., Carney, R. L., McKinnon, A. D., and Seymour, J. R. (2017). Diversity and activity of diazotrophs in Great Barrier Reef surface waters. Front. Microbiol. 8:967. doi: 10.3389/fmicb.2017.00967

Mikaelyan, A. S., Malej, A., Shiganova, T. A., Turk, V., Sivkovitch, A. E., Musaeva, E. I., et al. (2014). Populations of red tide forming dinoflagellate Noctiluca scintillnas (McCartney): a comparison between the Black Sea and the northern Adriatic Sea. Harmful Algae 33, 29-40. doi: 10.1016/j.hal.2014.01.004

Millennium Ecosystem Assessment [MEA] (2005). Ecosystems, and Human WellBeing: Current state, and Trends. (Coastal)Systems. Washington, D.C: Island Press.

Mills, C. E. (2001). Jellyfish blooms: are populations increasing globally in response to changing ocean conditions? Hydrobiologia 451, 55-68. doi: 10.1007/978-94010-0722-1_6

Mitsch, W. J., Day, J. W., Zhang, L., and Lane, R. R. (2005). Nitrate-nitrogen retention in wetlands in the Mississippi River Basin. Ecol. Eng. 24, 267-278. doi: 10.1016/j.ecoleng.2005.02.005

Montanari, A. (2012). Hydrology of the Po River: looking for changing patterns in river discharge. Hydrol. Earth Syst. Sci. 16, 3739-3747. doi: 10.5194/hess-163739-2012

Mozetič, P., Solidoro, C., Cossarini, Socal, G., Precali, R., Francé, J., et al. (2010). Recent trends towards oligotrophication of the northern Adriatic: evidence from chlorophyll a time series. Estuar. Coasts 33, 362-375. doi: 10.1007/s12237009-9191-7

Murphy, R. R., Kemp, W. M., and Ball, W. P. (2011). Long-term trends in Chesapeake Bay seasonal hypoxia, stratification, and nutrient loading. Estuar. Coasts 34, 1293-1309. doi: 10.1007/s12237-011-9413-7
National Research Council [NRC] (2000). Clean Coastal Waters: Understanding and Reducing the Effects of Nutrient Pollution. Washington, DC: The National Academies Press, doi: 10.17226/9812

Neumann, B., Vafeidis, A. T., Zimmermann, J., and Nicholls, R. J. (2015). Future coastal population growth and exposure to sea-level rise and coastal flooding - A Global Assessment. PLoS One 10:e0118571. doi: 10.1371/journal.pone.0118571

Newell, R. I. E. (1988). "Ecological changes in Chesapeake Bay: are they the result of overharvesting the American oyster (Crassostrea virginica)?, in Understanding the Estuary - Advances in Chesapeake Bay Research, Vol. 129, eds M. P. Lynch and E. C. Krome (Baltimore, MD: Chesapeake Research Consortium), 536-546.

Newton, A., Carruthers, T. J. B., and Icely, J. (2012). The coastal syndromes and hotspots on the coast. Estuar. Coast. Shelf Sci. 96, 39-47. doi: 10.1016/j.ecss. 2011.07.012

Newton, A., Icely, J. D., Falcão, M., Nobre, A., Nunes, J. P., Ferreira, J. G., et al. (2003). Evaluation of eutrophication in the Ria Formosa coastal lagoon. Portugal. Continental Shelf Res. 23, 1945-1961. doi: 10.1016/j.csr.2003.06.008

Ngatia, L., Grace, J. M. III, Moriasi, D., and Taylor, R. (2019). "Nitrogen and phosphorus eutrophication in marine ecosystems," in Monitoring of Marine Pollution, ed. H. B. Fouzia (London: IntechOpen), doi: 10.5772/intechopen. 81869

Niemeijer, D., and de Groot, R. S. (2008). A conceptual framework for selecting environmental indicator sets. Ecol. Indic. 8, 14-25. doi: 10.1016/j.ecolind.2006. 11.012

Ninfo, A., Ciavola, P., and Billi, P. (2018). The Po Delta is restarting progradation: geomorphological evolution based on a 47-years Earth Observation dataset. Sci. Rep. 8:3457. doi: 10.1038/s41598-018-21928-3

Nixon, S. W. (1995). Coastal marine eutrophication: a definition, social causes, and future concerns. Ophelia 41, 199-219. doi: 10.1080/00785236.1995.1042 2044

Nixon, S. W. (2009). Eutrophication and the macroscope. Hydrobiologia 629, 5-19. doi: 10.1007/978-90-481-3385-7_2

Officer, C. B., Biggs, R. B., Taft, J. L., Cronin, L. E., Tyler, M. A., and Boynton, W. R. (1984). Chesapeake Bay anoxia: origin, development, and significance. Science 223, 22-27. doi: 10.1126/science.223.4631.22

Officer, C. B., Smayda, T. J., and Mann, R. (1982). Benthic filter feeding: a natural eutrophication control. Mar. Ecol. Prog. Ser. 9, 203-210. doi: 10.3354/ meps009203

O’Higgins, T., Tett, P., Farmer, A., Cooper, P., Dolch, T., Friedrich, et al. (2014). Temporal constraints on ecosystem management: definitions and examples from Europe's regional seas. Ecol. Soc. 19:46. doi: 10.5751/ES-06507-19 0446

Ohkushi, K., Kennett, J. P., Zeleski, C. M., Moffitt, S. E., Hill, T. M., Robert, C., et al. (2013). Quanti?ed intermediate water oxygenation history of the NE Paci?c: a new benthic foraminiferal record from Santa Barbara basin. Paleoceanography 28, 453-467. doi: 10.1002/palo.20043

Olofsson, M., Klawonn, I., and Karlson, B. (2020). Nitrogen fixation estimates for the Baltic Sea indicate high rates for the previously overlooked Bothnian Sea. Ambio doi: 10.1007/s13280-020-01331-x [Online ahead of print]

O'Reilly, J. E. (2017). Transboundary Waters Assessment Programme (TWAP), Status and Trends in primary productivity and chlorophyll from 1996 to 2014 in Large Marine Ecosystems and the Western Pacific Warm Pool, based on data from satellite ocean colour sensors. Paris: IOC-UNESCO.

Orth, R. J., Carruthers, T. J. B., Dennison, W. C., Duarte, C. M., Fourqurean, J. W., Heck, K. L., et al. (2006). A global crisis for seagrass ecosystems. BioScience 56, 987-996.

Orth, R. J., Marion, S. R., Moore, K. A., and Wilcox, D. J. (2010). Eelgrass (Zostera marina L.) in the Chesapeake Bay region of Mid-Atlantic Coast of the USA: challenges in conservation and restoration. Estuar. Coasts 33, 139-150. doi: 10.1007/s12237-009-9234-0

Orth, R. J., and Moore, K. A. (1983). Chesapeake Bay: an unprecedented decline in submerged aquatic vegetation. Science 222, 51-53. doi: 10.1126/science.222. 4619.51

Ott, J. (1992). "The Adriatic benthos: problems and perspectives," in Proceedings of the Marine Eutrophication and Population Dynamics, 25th European Marine Biology Symposium, eds G. Colombo, L. Ferrari, V. U. Ceccherelli, and R. Rossi (Ferrara: University of Ferrara), 367-378. 
Paerl, H. W. (2006). Assessing and managing nutrient-enhanced eutrophication in estuarine and coastal waters: interactive effects of human and climatic perturbations. Ecol. Eng. 26, 40-54. doi: 10.1016/j.ecoleng.2005.09.006

Paerl, H. W. (2018). Why does N-limitation persist in the world's marine waters? Mar. Chem. 206, 1-6. doi: 10.1016/j.marchem.2018. 09.001

Paerl, H. W., Dennis, R. L., and Whitall, D. R. (2002). Atmospheric deposition of nitrogen: implications for nutrient over-enrichment of coastal waters. Estuaries 25, 677-693. doi: 10.1007/bf02804899

Paerl, H. W., Hall, N. S., Hounshell, A. G., Luettich, R. A. Jr., Rossignol, K. L., Osburn, C. L., et al. (2019). Recent increase in catastrophic tropical cyclone flooding in coastal North Carolina. USA: long-term observations suggest a regime shift. Nat. Sci. Rep. 9:10620. doi: 10.1038/s41598-01946928-9

Paerl, H. W., Hall, N. S., Peierls, B. L., and Rossignol, K. L. (2014). Evolving paradigms and challenges in estuarine and coastal eutrophication dynamics in a culturally and climatically stressed world. Estuar. Coasts 37, 243-258. doi: 10.1007/s12237-014-9773-x

Paerl, H. W., Scott, J. T., McCarthy, M. J., Newell, S. E., Gardner, W. S., Havens, K. E., et al. (2016). It takes two to tango: when and where dual nutrient (N \& P) reductions are needed to protect lakes and downstream ecosystems. Environ. Sci. Technol. 50, 10805-10813. doi: 10.1021/acs.est.6b02575

Parsons, M. L., and Dortch, Q. (2002). Sedimentological evidence of an increase in Pseudo-nitzschia (Bacillariophyceae) abundance in response to coastal eutrophication. Limnol. Oceanogr. 47, 551-558. doi: 10.4319/lo.2002.47. 2.0551

Penuelas, J., Poulter, B., Sardans, J., Ciais, P., van der Velde, M., Bopp, L., et al. (2013). Human-induced nitrogen-phosphorus imbalances alter natural and managed ecosystems across the globe. Nat. Commun. 4:2934. doi: 10.1038/ ncomms 3934

Pettine, M., Patrolecco, L., Camusso, M., and Crescenzio, S. (1998). Transport of carbon and nitrogen to the Northern Adriatic Sea by the Po River. Estuar. Coast. Shelf Sci. 46, 127-142. doi: 10.1006/ecss.1997.0303

Peyronnin, N. S., and Condrey, R. (2017). Using Louisiana's coastal history to innovate its coastal future. Shore Beach 85, 34-38.

Piontek, J., Endres, S., Le Moigne, F. A. C., Schartau, M., and Engel, A. (2019). Relevance of nutrient-limited phytoplankton production and its bacterial remineralization for carbon and oxygen fluxes in the Baltic Sea. Front. Mar. Sci. 6:581. doi: 10.3389/fmars.2019.00581

Pistocchi, R., Guerrini, F., Pezzolesi, L., Riccardi, M., Vanucci, S., Ciminiello, P., et al. (2012). Toxin levels and profiles in microalgae from the north-western Adriatic Sea - 15 years of studies on cultured species. Mar. Drugs 10, 140-162. doi: $10.3390 / \mathrm{md} 10010140$

Pliñski, M., Mazur-Marzec, H., Jóźwiak, T., and Kobos, J. (2007). The potential causes of cyanobacterial blooms in Baltic Sea estuaries. Oceanol. Hydrobiol. Stud. 36, 134-137.

Poikane, S., Kelly, M. G., Herrero, F. S., Pitt, J.-A., Jarvie, H. P., Claussen, U., et al. (2019). Nutrient criteria for surface waters under the European Water Frame-work Directive: current state-of-the-art, challenges and future outlook. Sci. Total Environ. 695:133888. doi: 10.1016/j.scitotenv.2019.133888

Pokhrel, B. K., and Paudel, K. P. (2019). Assessing the efficiency of alternative best management practices to reduce nonpoint source pollution in a rural watershed located in Louisiana. USA. Water 11:1714. doi: 10.3390/w1108 1714

Polimene, L., Pinardi, N., Zavatarelli, M., and Colella, S. (2006). The Adriatic Sea ecosystem seasonal cycle: validation of a three-dimensional numerical model. J. Geophys. Res. 111:C03S19. doi: 10.1029/2005JC003260

Pritchard, D. W. (1967). "What is an estuary: physical viewpoint," in Estuaries, ed. G. H. Lauff (Washington, D.C: American Association for the Advancement of Science), 3-5.

Pugnetti, A., Armeni, M., Camatti, E., Crevatin, E., Dell'Anno, A., Del Negro, P., et al. (2005). Imbalance between phytoplankton production and bacterial carbon demand in relation to mucilage formation in the Northern Adriatic Sea. Sci. Total Environ. 353, 162-177. doi: 10.1016/j.scitotenv.2005.09.014

Pugnetti, A., Camatti, E., Mangoni, O., Morabito, G., Oggioni, A., and Saggiomo, V. (2006). Phytoplankton production in Italian freshwater and marine ecosystems: state of art and perspectives. Chem. Ecol. 22, S49-S69.
Pulido-Velazquez, M., and Ward, F. A. (2017). "Comparison of Water Management Institutions and Approaches in the United States and EuropeWhat Can We Learn from Each Other?," in Competition for Water Resources Experiences and Management Approaches in the US and Europe, eds J. R. Ziolkowska and J. M. Peterson (Amsterdam: Elsevier), 423-444.

Purcell, J. E., Uye, S., and Lo, W. T. (2007). Anthropogenic causes of jelly?sh blooms and their direct consequences for humans: a review. Mar. Ecol. Progr. Ser. 350, 153-174. doi: 10.3354/meps07093

Qian, W., Dai, M., Xu, M., Kao, S., Du, C., Liu, J., et al. (2107). Non-local drivers of the summer hypoxia in the East China Sea off the Changjiang Estuary. Estuar. Coast. Shelf Sci. 198(Part B), 393-399. doi: 10.1016/j.ecss.2016.08.032

Rabalais, N. N., Diaz, R. J., Levin, L. A., Turner, R. E., Gilbert, D., and Zhang, J. (2010). Dynamics and distribution of natural and human-caused hypoxia. Biogeosciences 7, 585-619. doi: 10.5194/bg-7-585-2010

Rabalais, N. N., and Turner, R. E. (2019). Gulf of Mexico hypoxia: past, present, and future. Bull. Limnol. Oceanogr. 28, 117-124. doi: 10.1002/lob.10351

Rabalais, N. N., Turner, R. E., Díaz, R. J., and Justić, D. (2009). Global change and eutrophication of coastal waters. ICES J. Mar. Sci. 66, 1528-1537. doi: 10.1093/icesjms/fsp047

Rabouille, C., Conley, D. J., Dai, M. H., Cai, W.-J., Chen, C. T. A., Lansard, B., et al. (2008). Comparison of hypoxia among four river-dominated ocean margins: the Changjiang (Yangtze), Mississippi, Pearl, and Rhone Rivers. Cont. Shelf Res. 28, 1527-1537. doi: 10.1016/j.csr.2008.01.020

Redfield, A. C. (1958). The biological control of chemical factors in the environment. Am. Sci. 46, 205-221.

Reece, K. S. (2015). "Monitoring for HAB species in VA waters of Chesapeake Bay during 2015: emerging HAB species in Chesapeake Bay," in Annual report to the Virginia Department of Health (\#VIMSHAB617FY16), (Richmond, VA).

Revelante, N., and Gilmartin, M. (1992). The lateral advection of particulate organic matter from the Po delta region during summer stratification, and its implications for the Northern Adriatic. Estuar. Coast. Shelf Sci. 35, 191-212. doi: 10.1016/s0272-7714(05)80113-1

Richardson, A. J., Bakun, A., Hays, G. C., and Gibbons, M. J. (2009). The jellyfish joyride: causes, consequences and management responses to a more gelatinous future. Trends Ecol. Evol. 24, 312-322. doi: 10.1016/j.tree.2009. 01.010

Riedel, B., Zuschin, M., and Stachowitsch, M. (2008). "Dead zones: a future worst-case scenario for Northern Adriatic biodiversity," in CIESM Workshop Monographs, No. 35, Ed. F. Briand (Monaco: CIESM Publisher).

Sangiorgi, F., and Donders, T. H. (2004). Reconstructing 150 years of eutrophication in the north-western Adriatic Sea (Italy) using dinoflagellate cysts, pollen and spores. Estuar. Coast. Shelf Sci. 60, 69-79. doi: 10.1016/j.ecss. 2003.12.001

Savchuk, O. P. (2018). Large-scale nutrient dynamics in the Baltic Sea, 1970-2016. Front. Mar. Sci. 5:95. doi: 10.3389/fmars.2018.00095

Schmale, O., Krause, S., Holtermann, P., Guerra, N. C. P., and Umlauf, L. (2016). Dense bottom gravity currents and their impact on pelagic methanotrophy at oxic/anoxic transition zones. Geophys. Res. Lett. 43, 5225-5232. doi: 10.1002/ $2016 \mathrm{gl} 1069032$

Schnetzer, A., Jones, B. H., Schaffner, R. A., Cetinić, I., Fitzpatrick, E., Miller, P. E., et al. (2013). Coastal upwelling linked to toxic Pseudo-nitzschia australis blooms in Los Angeles coastal waters, 2005-2007. J. Plankton Res. 35, 1080-1092. doi: 10.1093/plankt/fbt051

Schubel, J. R., and Pritchard, D. W. (1986). Responses of upper Chesapeake Bay to variations in discharge of the Susquehanna River. Estuaries 9, 236-249.

Seitzinger, S. P., and Giblin, A. E. (1996). Estimating denitrification in North Atlantic continental shelf sediments. Biogeochemistry 35, 235-260. doi: 10. 1007/bf02179829

Seitzinger, S. P., Mayorga, E., Bouwman, A. F., Kroeze, C., Beusen, A. H. W., Billen, G., et al. (2010). Global river nutrient export: a scenario analysis of past and future trends. Glob. Biogeochem. Cycles 24:GB0A08. doi: 10.1029/ 2009GB003587

Sellner, K. G., and Fonda Umani, S. (1999). "Dinoflagellate blooms and mucilage production," in Ecosystems at the Land-Sea Margin: Drainage Basin to Coastal Sea, Vol. 55, eds T. C. Malone, A. Malej, L. W. Harding, N. Smodlaka, and R. E. Turner (Washington, DC: American Geophysical Union), 173-206. doi: 10.1029/ce055p0173 
Selman, M., and Greenhalgh, S. (2010). Eutrophication: sources and drivers of nutrient pollution. Renew. Resour. J. 26, 19-26.

Shen, J., and Wang, H. V. (2007). Determining the age of water and long-term transport timescale of the Chesapeake Bay. Estuar. Coast. ShelfSci. 74, 750-763.

Sherman, K. (1991). The Large Marine Ecosystem concept: research and management strategy for living marine resources. Ecol. Appl. 1, 349-360. doi: $10.2307 / 1941896$

Sinha, E., Michalak, A. M., and Balaji, V. (2017). Eutrophication will increase during the 21 st century as a result of precipitation changes. Science 357, 405-408. doi: 10.1126/science.aan2409

Sipiä, V. O., Lahti, K., Kankaanpää, H. T., Vuorinen, P. J., Meriluoto, J. A. O. (2002). Screening for cyanobacterial hepatotoxins in herring and salmon from the Baltic Sea. Aquatic Ecosyst. Health Manag. 5, 451-456. doi: 10.1080/ 14634980290001959

Skinner, M. P., Lewis, R. J., and Morton, S. (2013). Ecology of the ciguatera causing dinoflagellates from the Northern Great Barrier Reef: changes in community distribution and coastal eutrophication. Mar. Pollut. Bull. 77, 210-219. doi: 10.1016/j.marpolbul.2013.10.003

Small, C., and Cohen, J. E. (2004). Continental physiography, climate, and the global distribution of human population. Curr. Anthropol. 45, 269-279.

Smith, E. M., and Kemp, W. M. (1995). Seasonal and regional variations in plankton community production and respiration for Chesapeake Bay. Mar. Ecol. Progr. Ser. 116, 217-231. doi: 10.3354/meps116217

Smith, S. V., Swaney, D. P., Talaue-McManus, L., Bartley, J. D., Sandhei, P. T., McLaughlin, C. J., et al. (2003). Humans, hydrology, and the distribution of inorganic nutrient loading to the ocean. BioScience 53, 235-245.

Solé, L., and Ariza, E. (2019). A wider view of assessments of ecosystem services in coastal areas: the perspective of social-ecological complexity. Ecol. Soc. 24:24. doi: 10.5751/ES-10883-240224

Solidoro, C., Bastianini, M., Bandelj, V., Codermatz, R., Cossarini, G., Canu, D. M., et al. (2009). Current state, scales of variability and decadal trends of biogeochemical properties in the Northern Adriatic Sea. J. Geophysical Res. 114:C07S91. doi: 10.1029/2008JC004838

Sonesten, L., Svendsen, L. M., Tornbjerg, H., Gustafsson, B., Frank-Kamenetsky, D., and Haapaniemi, J. (2018). "Sources and pathways of nutrients to the Baltic Sea. HELCOM PLC-6," in Proceedings of the Baltic Sea Environment (Helsinki Commission - HELCOM), Baltic Sea Environment Proceedings, (Gland: IUCN), 153.

Spilling, K., Olli, K., Lehtoranta, J., Kremp, A., Tedesco, L., Tamelander, T., et al. (2018). Shifting diatom-dinoflagellate dominance during spring bloom in the Baltic Sea and its potential effects on biogeochemical cycling. Front. Mar. Sci. 5:327. doi: $10.3389 /$ fmars.2018.00327

Spokes, L. J., and Jickells, T. D. (2005). Is the atmosphere really an important source of reactive nitrogen to coastal waters? Continental Shelf Res. 25, 2022-2035. doi: 10.1016/j.csr.2005.07.004

Stachowitsch, M. (1984). Mass mortality in the Gulf of Trieste: the course of community destruction. Mar. Ecol. 5, 243-264. doi: 10.1111/j.1439-0485.1984. tb00124.x

Staresinié, N., von Brokel, K., Smodlaka, N., and Clifford, H. (1982). A comparison of moored and free drifting sediment traps of two different designs. J. Mar. Res. 40, 273-291.

Steffen, W., Richardson, K., Rockström, J., Cornell, S. E., Fetzer, I., Be, E. M., et al. (2015). Planetary boundaries: guiding human development on a changing planet. Science 347, 1259855-1259851.

Steidinger, K. A., Vargo, G. A., Tester, P. A., Tomas, G. R. (1998). "Bloom dynamics and physiology of Gymnodinium breve, with emphasis on the Gulf of Mexico," in Physiological Ecology of HarmfulAlgal Blooms, eds E. M. Anderson, A. D. Cembella, and G. M. Hallengraff (New York, NY: Springer), 135-153.

Stigebrandt, A. (2001). Physical oceanography of the Baltic Sea. In: A Systems Analysis of the Baltic Sea. Berlin: Springer, 19-74.

Strain, P. M., and Hargrave, B. T. (2005). "Salmon aquaculture, nutrient fluxes and ecosystem processes in Southwestern New Brunswick," in Environmental Effects of Marine Finfish Aquaculture, Handbook of Environmental Chemistry, ed. B. T. Hargrave (Berlin: Springer), 29-57. doi: 10.1007/b136003

Stramma, L. S., Schmidtko, S., Levin, L. A., Johnson, G. C. (2010). Ocean oxygen minima expansions and their biological impacts. Deep Sea Res. I 57, 587-595. doi: 10.1016/j.dsr.2010.01.005
Strokal, M., Kahil, T., Wada, Y., Albiac, J., Bai, Z., Ermolieva, T., et al. (2020). Costeffective management of coastal eutrophication: a case study for the Yangtze river basin. Resour. Conserv. Recycl. 154:1046352.

Sun, S., Sun, X., and Jenkinson, I. R. (2015). Giant jellyfish blooms in Chinese waters. Hydrobiologia 754, 1-11. doi: 10.1007/s10750-015-2320-3

Swaney, D. P., Hong, B., Ti, C., Howarth, R. W., and Humborg, C. (2012). Net anthropogenic nitrogen inputs to watersheds and riverine $\mathrm{N}$ export to coastal waters: a brief overview. Curr. Opin. Environ. Sustain. 4, 203-211. doi: 10.1016/ j.cosust.2012.03.004

Tang, D., Di, B., Wei, G., Ni, I. H., and Wang, S. (2006). Spatial, seasonal and species variations of harmful algal blooms in the South Yellow Sea and East China Sea. Hydrobiologia 568, 245-253. doi: 10.1007/s10750-006-0108-1

Tango, P., Magnien, R., Butler, W., Luckett, C., Luckenbach, M., Lacouture, R., et al. (2005). Impacts and potential effects due to Prorocentrum minimum blooms in Chesapeake Bay. Harmful Algae 4, 525-531. doi: 10.1016/j.hal.2004.08.014

Testa, J. M., Clark, J. B., Dennison, W. C., Donovan, E. C., Fisher, A. W., Ni, W., et al. (2017). Ecological forecasting and the science of hypoxia in Chesapeake Bay. BioScience 67, 614-626.

Testa, J. M., Lyubchich, V., and Zhang, Q. (2019). Patterns and trends in Secchi disk depth over three decades in the Chesapeake Bay estuarine complex. Estuar. Coasts 42, 927-943. doi: 10.1007/s12237-019-00547-9

Theuerkauf, S. J., Eggleston, D. B., and Puckett, B. J. (2019a). Integrating ecosystem services considerations within a GIS-based habitat suitability index for oyster restoration. PLoS One 14:e0210936. doi: 10.1371/journal.pone.0210936

Theuerkauf, S. J., Morris, J. A., Waters, T. J., Wickliffe, L. C., Alleway, H. K., and Jones, R. C. (2019b). A global spatial analysis reveals where marine aquaculture can benefit nature and people. PLoS One 14:e222282. doi: 10.1371/journal. pone. 0222282

Tong, Y., Zhao, Y., Zhen, G., Chi, J., Liu, X., Lu, Y., et al. (2015). Nutrient loads flowing into coastal waters from the main rivers of China (2006-2012). Sci. Rep. 5:16678. doi: 10.1038/srep16678

Totti, C., Cangini, M., Ferrari, C., Kraus, R., Pompei, M., Pugnettie, A., et al. (2005). Phytoplankton size-distribution and community structure in relation to mucilage occurrence in the northern Adriatic Sea. Sci. Total Environ. 353, 204-217. doi: 10.1016/j.scitotenv.2005.09.028

Totti, C., Romagnoli, T., Accoroni, S., Coluccelli, A., Pellegrini, M., Campanelli, A., et al. (2019). Phytoplankton communities of the northern Adriatic Sea: interdecadal variability over a 30 year period (1988-2016) and relationships with meteoclimatic drivers. J. Mar. Syst. 193, 137-153. doi: 10.1016/j.jmarsys. 2019.01.007

Townhill, B. L., Tinker, J., Jones, M., Pitois, S., Creach, V., Simpson, S. D., et al. (2018). Harmful algal blooms and climate change: exploring future distribution changes. ICES J. Mar. Sci. 75, 1882-1893. doi: 10.1093/icesjms/fsyl13

Turner, R. E., and Rabalais, N. N. (2013). Nitrogen and phosphorus phytoplankton growth limitation in the northern Gulf of Mexico. Aquat. Microb. Ecol. 68, 159-169. doi: 10.3354/ame01607

Turner, R. E., Rabalais, N. N., Alexander, R. B., McIsaac, G., and Howarth, R. W. (2007). Characterization of nutrient, organic carbon, and sediment loads and concentrations from the Mississippi River into the Northern Gulf of Mexico. Estuar. Coasts 30, 773-790. doi: 10.1007/bf02841333

Ujević, Ž, Ninčević-Gladan, R., Roje, S., Skejić, S., Arapov, J., and Marasović, I. (2010). Domoic acid-a new toxin in the Croatian Adriatic shellfish toxin profile. Molecules 15, 6835-6849. doi: 10.3390/molecules15106835

UNESCO. (2012). Requirements for Global Implementation of the Strategic Plan for Coastal GOOS. GOOS Report 193. Intergovernmental Oceanographic Commission. Paris: UNESCO, $1-200^{38}$.

United Nations Environment Programme [UNEP] (2006). Marine, and Coastal Ecosystems, and Human Wellbeing: A Synthesis Report Based on the Findings of the. Millennium Ecosystem Assessment. Nairobi: UNEP.

Valiela, I., Kinney, E., Culbert, J., Peacock, E., and Smith, S. (2009). "Global losses of mangroves and salt marshes," in Global Loss of Coastal Habitats: Rates, Causes and Consequences, ed. C. M. Duarte (Bilbao: Fundaci'on BBVA), 109-142.

van Apeldoorn, M. E., van Egmond, H. P., Speijers, G. J., and Bakker, G. J. (2007). Toxins of cyanobacteria. Mol. Nutr. Food Res. 51, 7-60.

\footnotetext{
${ }^{38} \mathrm{http}: / /$ unesdoc.unesco.org/ulis/.
} 
van Drecht, G., Bouwman, A. F., Harrison, J., and Knoop, J. M. (2009). Global nitrogen and phosphate in urban wastewater for the period 1970 to 2050. Glob. Biogeochem. Cycles 23:GB0A03. doi: 10.1029/2009GB003458

Vaquer-Sunyer, R., and Duarte, C. M. (2008). Thresholds of hypoxia for marine biodiversity. Proc. Nat. Acad. Sci. U.S.A. 105, 15452-15457. doi: 10.1073/pnas. 0803833105

Vasas, V., Lancelot, C., Rousseau, V., and Jordán, F. (2007). Eutrophication and overfishing in temperate nearshore pelagic food webs: a network perspective. Mar. Ecol. Prog. Ser. 336, 1-14. doi: 10.3354/meps336001

Vega-Thurber, R. L., Burkepile, D. E., Fuchs, C., Shantz, A. A., McMinds, R., and Zaneveld, J. R. (2014). Chronic nutrient enrichment increases prevalence and severity of coral disease and bleaching. Glob. Change Biol. 20, 544-554. doi: $10.1111 /$ gcb. 12450

Vitousek, P. M., Aber, J. D., Howarth, R. W., Likens, G. E., Matson, P. A., Schindler, D. W., et al. (1997). Human alteration of the global nitrogen cycle: sources and consequences. Ecol. Appl. 7, 737-750. doi: 10.1890/1051-0761(1997)007[0737: haotgn]2.0.co;2

Wallace, R. B., Baumann, H., Grear, J. S., Aller, R. C., and Gobler, C. J. (2014). Coastal ocean acidification: the other eutrophication problem. Estuar. Coast. Shelf Sci. 148, 1-13. doi: 10.1016/j.ecss.2014.05.027

Wang, B., and Wang, X. (2007). Chemical hydrography of coastal upwelling in the East China Sea. Chin. J. Oceanol. Limnol. 25, 16-26. doi: 10.1007/s00343-0070016-x

Wang, H., Dai, M., Liu, J., Kao, S.-J., Zhang, C., Cai, W.-J., et al. (2016). Eutrophication-driven hypoxia in the East China Sea off the Changjiang Estuary. Environ. Sci. Technol. 50, 2255-2263. doi: 10.1021/acs.est.5b06211

Wang, J., and Wu, J. (2009). Occurrence and potential risks of harmful algal blooms in the East China Sea. Sci. Total Environ. 407, 4012-4021. doi: 10.1016/j. scitotenv.2009.02.040

Wang, J., Yan, W., Chen, N., Li, X., and Liu, L. (2015). Modeled long-term changes of DIN: DIP ratio in the Changjiang River in relation to Chl- $\alpha$ and DO concentrations in adjacent estuary. Estuar. Coast. Shelf Sci. 166, 153-160. doi: 10.1016/j.ecss.2014.11.028

Wang, R., Li, X., Hou, L., Liu, M., Zheng, Y., Yin, G., et al. (2018). Nitrogen fixation in surface sediments of the East China Sea: occurrence and environmental implications. Mar. Pollut. Bull. 137, 542-548. doi: 10.1016/j.marpolbul.2018. 10.063

Wang, Y., Hendy, I., and Napier, T. J. (2017). Climate and anthropogenic controls of coastal deoxygenation on interannual to centennial timescales. Geophys. Res. Lett. 44, 528-536. doi: 10.1002/2017GL075443

Wang, Y., Jiang, H., Zhang, X., and Jin, J. (2014). Spatial and temporal distribution of sea surface salinity in coastal waters of China based on Aquarius. IOP Conf. Series 17:012116. doi: 10.1088/1755-1315/17/1/012116

Wang, Y., Ridd, P. V., Heron, M. L., Stieglitz, T. C., and Orpin, A. R. (2007). Flushing time of solutes and pollutants in the central Great Barrier Reef lagoon. Australia. Mar. Freshw. Res. 58, 778-791.

Wang, Y.-F., Yu, R.-C., Lu, D.-D., Lü, S.-H., Zhub, D.-D., Zhang, C. S., et al. (2018). Recurrent toxic blooms of Alexandrium spp. in the East China Sea - Potential role of Taiwan Warm Current in bloom initiation. J. Ecol. Toxicol. 2:115.

Warrick, J. A., Washburn, L., Brzezinski, M. A., Siegel, D. A. (2005). Nutrient contributions to the Santa Barbara Channel, California, from the ephemeral Santa Clara River. Estuar. Coast. Shelf Sci. 62, 559-574. doi: 10.1016/j.ecss.2004. 09.033

Wasmund, N., Nausch, G., Schneider, B., Nagel, K., and Voss, M. (2005). Comparison of nitrogen fixation rates determined with different methods: a study in the Baltic Proper. Mar. Ecol. Prog. Ser. 297, 23-31. doi: 10.3354/ meps 297023

Wasmund, N., Voss, M., and Lochte, K. (2001). Evidence of nitrogen fixation by non-heterocystous cyanobacteria in the Baltic Sea and re-calculation of a budget of nitrogen fixation. Mar. Ecol. Prog. Ser. 214, 1-14. doi: 10.3354/meps214001

Waters, C. N., Zalasiewicz, J., Summerhayes, C., Barnosky, A. D., Poirier, C., Gałuszka, A., et al. (2016). The Anthropocene is functionally and stratigraphically distinct from the Holocene. Science 351:aad2622. doi: 10.1126/ science.aad 2622

Waycott, M., Duarte, C. M., Carruthers, T. J. B., Orth, R. J., Dennison, W. C., Olyarnik, S., et al. (2009). Accelerating loss of seagrasses across the globe threatens coastal ecosystems. Proc. Nat. Acad. Sci. U.S.A. 106, 12377-12381. doi: 10.1073/pnas.0905620106
White, J. R., and Roman, M. R. (1992). Seasonal study of grazing by metazoan zooplankton in the mesohaline Chesapeake Bay. Mar. Ecol. Progr. Ser. 86, 251-261. doi: 10.3354/meps086251

World Water Assessment Programme [WWAP] (2017). The United Nations World Water Development Report 2017. (Wastewater): The Untapped Resource. Paris: United Nations Educational, Scientific and Cultural Organization.

Worm, B., Barbier, E. B., Beaumont, N., Duffy, J. E., Folke, C., Halpern, B. S., et al. (2006). Impacts of biodiversity loss on ocean ecosystem services. Science 314, 787-790.

Wu, G., Cao, W., Wang, F., Su, X., Yan, Y., and Guan, Q. (2019). Riverine nutrient fluxes and environmental effects on China's estuaries. Sci. Total Environ. 661, 130-137. doi: 10.1016/j.scitotenv.2019.01.120

Wu, H., Zhu, J., Shen, J., and Wang, H. (2011). Tidal modulation on the Changiiang River plume in summer. J. Geophys. Res. 116:C08017. doi: 10.1029/ 2011JC007209

Wurtsbaugh, W. A., Paerl, H. W., and Dodds, W. K. (2019). Nutrients, eutrophication and harmful algal blooms along the freshwater to marine continuum. Wiley Interdiscipl. Rev. 6:e1373. doi: 10.1002/wat2.1373

Xiong, Y., and Berger, C. R. (2010). Chesapeake Bay tidal characteristics. J. Water Resour. Protect. 2, 619-628. doi: 10.4236/jwarp.2010.27071

Xiuren, N., Vaulot, D., Zhensheng, L., and Zilin, L. (1988). Standing stock and production of phytoplankton in the estuary of the Changjiang (Yangtse River) and the adjacent East China Sea. Mar. Ecol. Prog. Ser. 9, 141-150. doi: 10.3354/ meps049141

Xu, H., Newton, A., Wolanski, E., and Chen, Z. (2015). The fate of phosphorus in Yangtze Estuary (Changjiang), China, under multi-stressors: hindsight and forecast. Estuar. Coast. Shelf Sci. 163(Part B), 1-6. doi: 10.1016/j.ecss.2015.05. 032

Yan, T., Zhou, M.-J., and Zou, J. Z. (2002). “A national report on harmful algal blooms in China," in Harmful Algal Blooms in the PICES Region of the North Pacific, eds F. J. R. Taylor and L. Vera (Sidney: PICES).

Yan, W., Mayorga, E., Li, X., Seitzinger, S. P., and Bouwman, A. F. (2010). Increasing anthropogenic nitrogen inputs and riverine DIN exports from the Changjiang River basin under changing human pressures. Glob. Biogeochem. Cycles 24:GB0A06. doi: 10.1029/2009GB003575

Zaneveld, J. R., Burkepile, D. E., Shantz, A. A., Pritchard, C. E., McMinds, R., Payet, J. P., et al. (2016). Overfishing and nutrient pollution interact with temperature to disrupt coral reefs down to microbial scales. Nat. Commun. 7:11833. doi: $10.1038 /$ ncomms 11833

Zhang, B., Tian, H., Lu, C., Dangal, S. R. S., Yang, J., and Pan, S. (2017). Global manure nitrogen production and application in cropland during 1860-2014: a 5 arcmin gridded global dataset for Earth system modeling. Earth Syst. Sci. Data 9, 667-678. doi: 10.5194/essd-9-667-2017

Zhang, F., Cui, Z., Chen, X., Ju, X., Shen, J., Chen, Q., et al. (2012). Integrated nutrient management for food security and environmental quality in China. Adv. Agron. 116, 1-40. doi: 10.1016/B978-0-12-394277-7.00001-4

Zhang, J., Guo, X., and Zhao, L. (2019). Tracing external sources of nutrients in the East China Sea and evaluating their contributions to primary production. Progr. Oceanogr. 176:102122. doi: 10.1016/j.pocean.2019.102122

Zhang, Q., Brady, D. C., and Ball, W. P. (2013). Long-term seasonal trends of nitrogen, phosphorus, and suspended sediment load from the non-tidal Susquehanna River Basin to Chesapeake Bay. Sci. Total Environ. 45, 208-221. doi: 10.1016/j.scitotenv.2013.02.012

Zhang, R., Chen, M., Cao, J., Ma, Q., Yang, J., and Qiu, Y. (2012). Nitrogen fixation in the East China Sea and southern Yellow Sea during summer 2006. Mar. Ecol. Prog. Ser. 447, 77-86. doi: 10.3354/meps09509

Zhou, C., Place, A. R., Yan, X., Xu, J., Luo, Q., William, E., et al. (2015). Interactions between Karlodinium veneficum and Prorocentrum donghaiense from the East China Sea. Harmful Algae 49, 50-57. doi: 10.1016/j.hal.2015.08.004

Zhou, M.-J., Shen, Z.-L., and Yu, R.-C. (2008). Responses of a coastal phytoplankton community to increased nutrient input from the Changjiang (Yangtze) River. Continental Shelf Res. 28, 1483-1489. doi: 10.1016/j.csr.2007. 02.009

Zhu, J. R., Zhu, Z. Y., Lin, J., Wu, H., and Zhang, J. (2016). Distribution of hypoxia and pycnocline off the Changjiang Estuary. China. J. Mar. Syst. 154, 28-40. doi: 10.1016/j.jmarsys.2015.05.002

Zhu, Z.-Y., Zhang, J., Wu, Y., Zhang, Y.-Y., Lin, J., and Liu, S.-M. (2011). Hypoxia off the Changjiang (Yangtze River) Estuary: oxygen depletion and organic 
matter decomposition. Mar. Chem. 125, 108-116. doi: 10.1016/j.marchem.2011. 03.005

Zoppini, A., Pettine, M., Totti, C., Puddu, A., Artegiani, A., and Pagnotta, R. (1995). Nutrients, standing crop and primary production in Western coastal waters of the Adriatic Sea. Estuar. Coast. Shelf Sci. 41, 493-513. doi: 10.1016/02727714(95)90024-1

Zuo, J. L., Song, J. M., Yuan, H. M., Li, X. G., Li, N., and Duan, L. Q. (2016). Particulate nitrogen and phosphorus in the East China Sea and its adjacent Kuroshio waters and evaluation of budgets for the East China Sea Shelf. Continental Shelf Res. 131, 1-11. doi: 10.1016/j.csr.2016.11.003
Conflict of Interest: The authors declare that the research was conducted in the absence of any commercial or financial relationships that could be construed as a potential conflict of interest.

Copyright (c) 2020 Malone and Newton. This is an open-access article distributed under the terms of the Creative Commons Attribution License (CC BY). The use, distribution or reproduction in other forums is permitted, provided the original author(s) and the copyright owner(s) are credited and that the original publication in this journal is cited, in accordance with accepted academic practice. No use, distribution or reproduction is permitted which does not comply with these terms. 